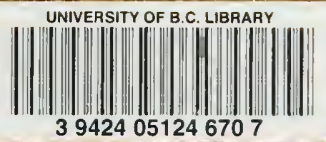

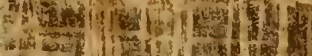

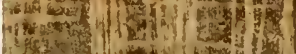

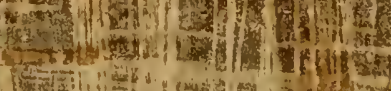

\section{.}

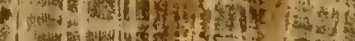




$$
\text { . }
$$


Technical Series, No. 20, Part I.

\section{U.B.C. LIBRARY}

U. S. DEPARTMENT $\$ F$ AGRICULTURE

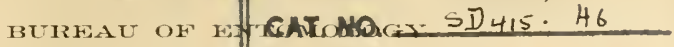

L. O. HOWARD, Entomolog t and Chief of Bureau.

ACC. NO.

TECHIICAL PAPEISS WX MISCELLANEOUS FOREST INSECTS.

\section{CONTRIBUTIONS TOW ARI) A MONOGRAPII}

OF THE BART-IVEEVILS OF THE (iENUS' P'SSODES.

BY

A. I. IIOPKINS, PH. D.,

In Charge of Forrist Inscet Inreatigations.

INELE1, JINCARY $7,1911$.

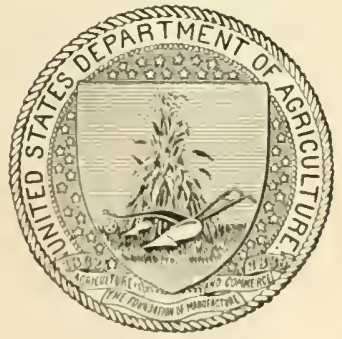

WANIINATON:

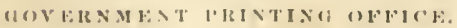

1911. 


\section{BUREALOF ENTOLOLOGY.}

L. O. Ilowa RD, Entomologist and Chief of Burcau.

c. L. Marlatt, Issistant Entomologist and Acting Chirf in .1bsence of Chief.

R. S. Clifton, Exccutive Issistant.

IV. F. TAstet, Chief Clork.

F. II. C'IITTENDEx, in charge of truek erop and stored preduet insect intestigations.

A. 1. I1OPKINs, in charge of forest insect incestigations.

W. D. II UNTER, in charge of southern field crop insect investigations.

F. N. We Bster, in charge of cereal and forage inseet invertigations.

A. L. QunNTANce, in charge of theciduous fruit instct intestigations.

E. F. Phinlips, in charge of ber cullure.

D. M. Rogers, in charge of preventing spread of moths, field uork.

ROLLA I'. ('vRrie, in chargi' of editorial work.

- Mabel folcord, librarian.

\section{Folekt INAEet fNiestigiations.}

1. D. Hopkins, in chargr.

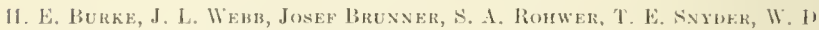
EDMonston, agents aud experts.

MARY E. FAUNCE, preparator.

Wir.tam Midheton, Mary (I. Johnson, student assistents. 


\section{LETTER OF TR.INSWITTAL.}

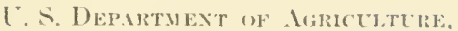

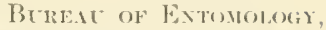 Whashingtou, I). ('.. July 25, 1910.}

Sir: I have the homor to transmit herewith mamseript of the first part of a bulletin of the techmionl series to be entitled "Teehnieal Papers on Miscellaneous Forest Inserts. 1. ('ontributions Townd at Jlonograpls of the Bark-wervils of the Genus Pisodes," by Dr. A. 1). IJopkins. Mthough the hark-werils are amoug the most important enemies of coniferous forest trees, and especially of the voung growtli, comparatively little has been known heretofore of the species: lance the special need for this contribution as a basis for economic investigations and publications. It rmborlies the result of extensive systrmatie work hy Ioxtor Ihopkins on new material contained in the colleetions of the Bureat of Entomology and the Enited States National Musenm and indeludes the descriptions of twenty-thres speries new to scienee.

I recommend the publication of this mammeript as Teehnical Series . No. 20, Part J, of the Burean of Entomoluery.

Rispertfully.

1.. (1. How प1RD,

lintomologist and thief of linraau.

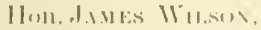

Socretary of Algrieullur. 



\section{P'RLFACE TO BLLLETIS.}

It is the purpose of this bulletin to inchule surle miserllaneous technical papers on insects, other than the scolyticl beetles, as are either injurious or beneficial and of more or less importance in their relation (1) Imerican forests. These papers are lased largely, if not entirely, on original observations and investigations, supplemented by material in the Inited states National Juseum, and serve as a necessary basis for the nonterduneal papers on the same inserts. As they are intented to be of serviee espeecially (o) the reonomice entomologist and to the student of forest entomolegry, they are, as a rule, presented in a somewhat less formal style than if intemiled for the systematiot only.

1. D. II. 
Digitized by the Internet Archive in 2010 with funding from University of British Columbia Library 


\section{(1) NTEXTS.}

IJisturical referenes. ... ............... .

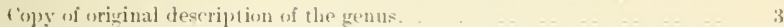

Translation of originat descripnion ...... ...

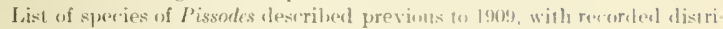
lution and losst trees. .............................. ti

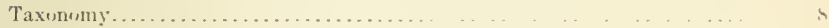

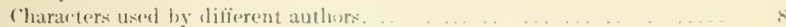

Sulurlinat and family characters. . . . . . . . . . . . . . . . . . . .

Tribal and subfamily characters. . . . . . . . . . . . . . . . . .

Revisiunal notes............. !

lieneric rharacters. ...........

Sulordinat and family chararters........ @

Inlominal sogments.............

Rovised daseilication.............. (1)

Sulorilinal to subfamily rharacers. 11

Girnerie characters.............

Anatomiond ilotals of tho arluls. ... .

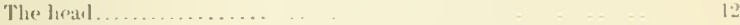

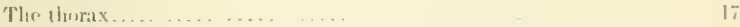

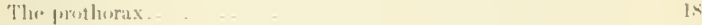

The mesesthorax...... ..

The metathris. . . ...

Tlie aluliment.... .

The wirus. ......

ImIrrmal anatumy ....

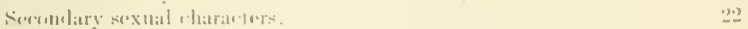

The regre. .......

The larvak..............

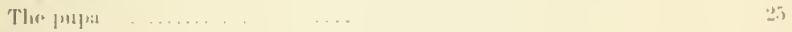

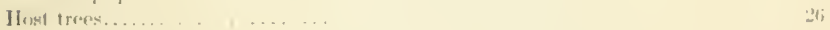

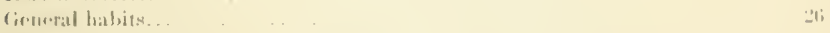

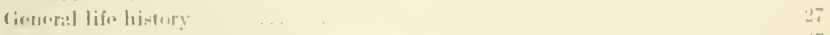

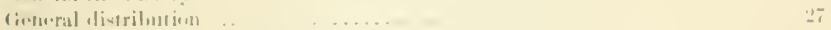

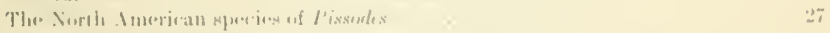

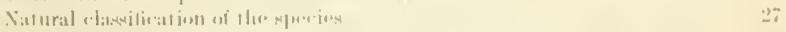

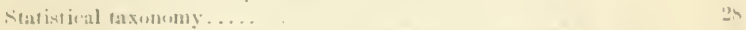

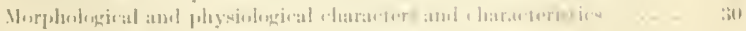

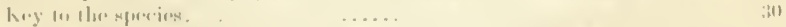

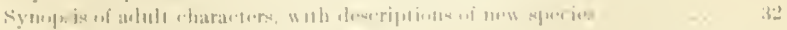

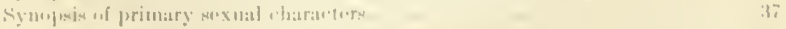

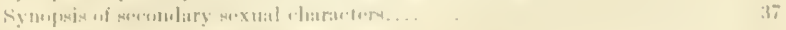

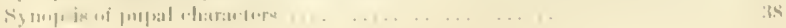


The North American species of Pissodes- C'ontinued. Page.

Synopsis of larval characters................................. $\quad 39$

Table of distribution....................................... 40

Table showing relations of species to host trees................... 41

Table of host trees...................................... 42

Characters common to the species of the genus................. 43

Characters common to the species of the major and ninor divisions..... 43

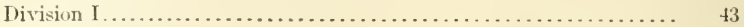

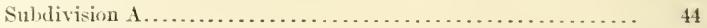

Section al.................................... 4

Subsection b1............................... 14

1. Pissodes similis......................... 44

2. Pissodes utahensis........................ 45

3. Pissodes barberi....................... 45

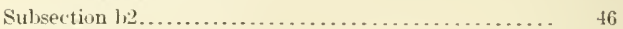

4. Pissodes sitchensis....................... 47

5. Pissorles engelmanni.................... 47

6. Pissodes strobi............................. 48

7. Pissodes approximatus................... 49

8. Pissodes schwarzi....................... . 50

9. Pissordes canadensis....................... 51

10. Pissodes nemorensis...................... 51

11. Pissodes deodara....................... 52

12. Pissodes californicus.................... 53

13. Pissodes yosemite ......................... 53

14. Pissodes vebbi.......................... 54

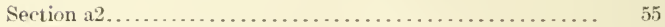

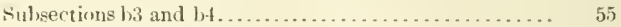

15. Pissodes radiatx......................... 55

16. Pissodes fasciatus........................ 56

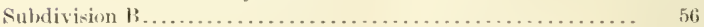

Sertion a.3.................................... 57

17. Pissodes costatus......................... 57

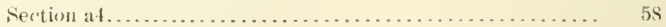

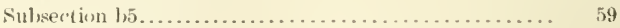

1.. Pissodes fiski........................... 59

19. I'issoles nigrx ............................ 59

20. Pissodes punticollis.................... (it)

21. I'issoles mutrayanx................... $\quad 60$

22. I'issodes coleradensis................... tit

23. I'issodes alasrensis.................... of

21. Pissods rolundetus.................. til

Subertion bit............................ 62

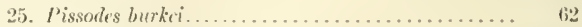

210. Pissodes piperi........................ 62

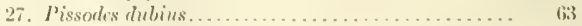

2.. I'issodes fraseri........................ 63

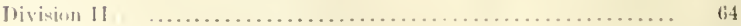

29. Pissodes a jimis......................... 6.4

30. P'issoles murrivi.......................... (i5)

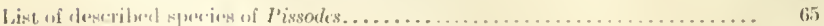

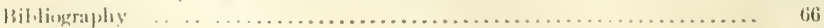




\section{ILLUSTRATIONS.}

PLATES.

I'ase.

Plate I. Claseification of the genus l'issodes, showing tochnical and

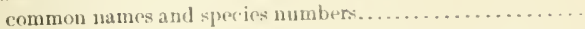

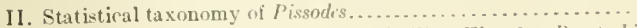

III. Adults of Pissodes. Fig. 1.-P. similis. Fig. 6.-P' strobi. Fig. 8.-P. schwarzi, Fig. 15,-I', radiate. Fig. 16.-I'.

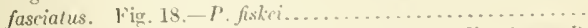

IV Adults of Pissodes. Fig. 20,-P', punctiollis. Fig. 24. I'. rotundatus. Fig. 25. $-P$. burkei. Fig. 26.- $P$, piperi.

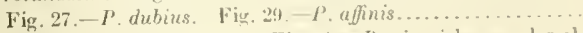

V. Larva and pupa of Pissodes. Fig. I. I'. piperi, larva-dorsal, lateral, and ventral aspects. Fig. $B .-I^{\prime}$, silchensis, pupa dorsal, ventral, and lateral asperta. . .................

VI. Pygal tergites of the aldomen of rissodes. Fig. 5, 9.- Tergite 7 of $P$. engelmanni. Fir. 5.8. Tergitess 7 and $s$ of $I^{\prime}$ cngelmanni. Fig. l.-Tergites 7 and $\&$ of $P$. strobi. lig. 7,8 . Tergites 7 and 8 of $l$. approrimatus. Fig. 2h. 8 .

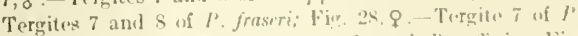

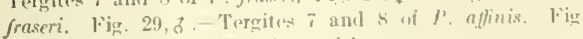

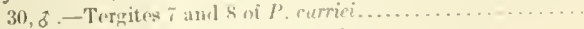

VII. Female reproductive organs of l'issodes.............. fis

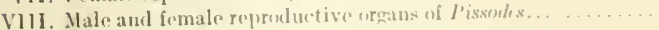

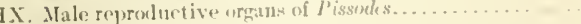

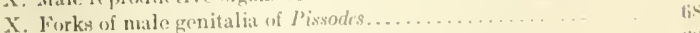

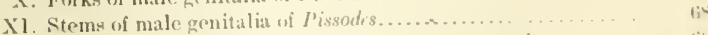

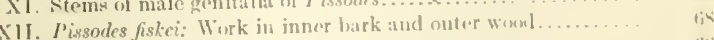

צill. Pissodes sitchensis: Work in terminal and tup.... . . . . .

XIV. Pissorks strobi: Work in terminals and tops................

XV. Work of Pissodes approrimatus and $I^{\prime}$. nemorousis in latk atul

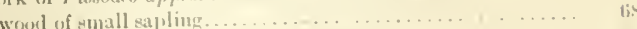

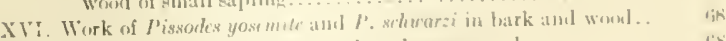

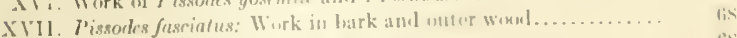

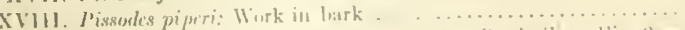

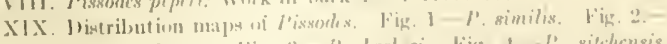

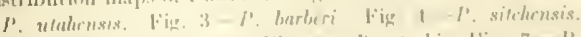

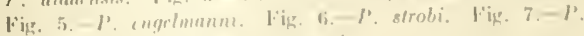

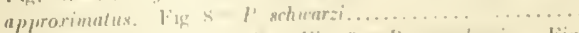

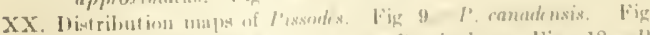

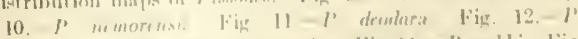

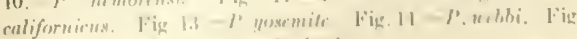

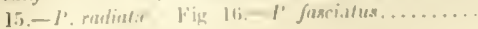


Fage.

Puate XX]. Distribution maps of Pissodes. Fig. 17.-P. costatus. Fig. 15.-P. fiskei. Fig. 19.-P.nigrx. Fig. 20,-P. puncticollis. Fig. 21. $-P$. murrayanix. Fig. 22. $-P$. coloradensis. Fig. 23.-P. alascensis. Fig. 24.-P. rolundatus.............

XXI1. Distribution maps of Pissodes. Fig. 25-P. burkei. Fig. 26.$P$. piperi. Fig. 27.-P. dubus. Fig. 28.-P. fraseri. Fig.

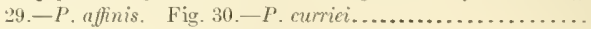

TEXT FIGURES.

FIc. 1. Pissodes strobi: llead, ventral aspect, and mouth parts............ 13

2. Pissodes strobi: llead, dorsal aspert, and mandibles.............. 14

3. Dendroctonus ralens: IIead, dorsal and lateral aspects .............. 15

4. Dendroctonus valens: Jlearl, ventral aspect, and mouth parts ........ 16

5. Pissodes sitchensis: Ilead of larva, dorsal aspect............... 23

6. Pissodes sitchensis: Head of larva, ventral aspect................. 2.

7. Pissodes sitchensis: IIead of larva, lateral aspect............... 25

8. A. Pissodes piperi: Front of head of larra .................. 26

B. Pissodes nemorensis: Front of head of larva................ 26

9. Pissodes fraseri: Lateral aspert, slowing method of determining individual index....................................... 28 


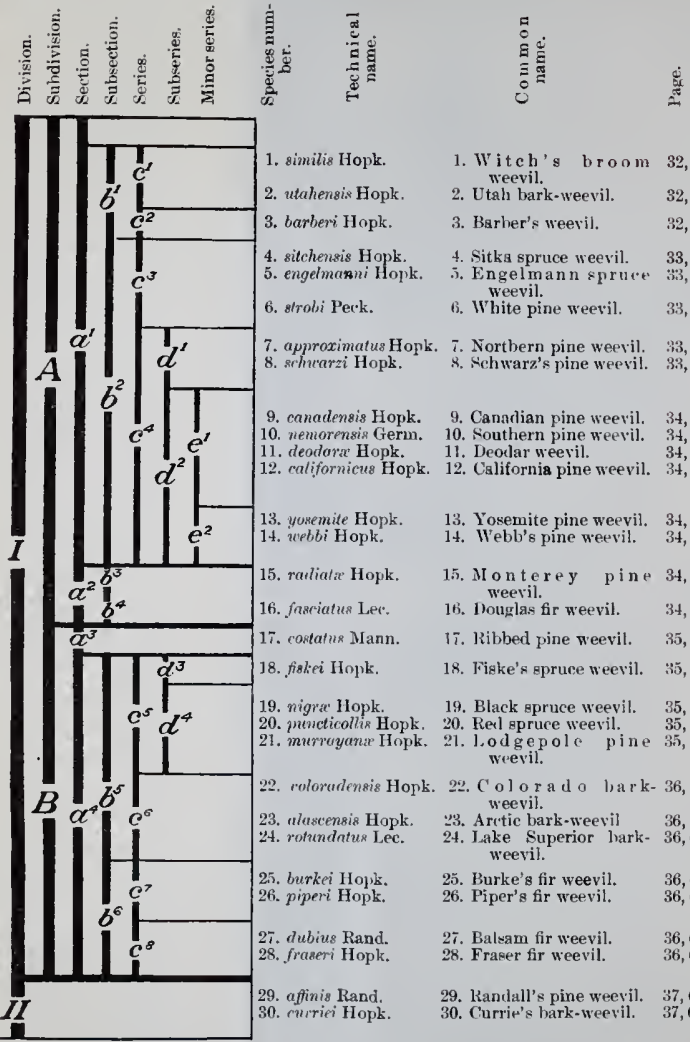
1. Witch's broom 32,44
weevil.

2. Utah bark-weevil. 32,45

3. Barber's weevil. $\quad 32,45$

4. Sitka spruce weevil. $33, \pm 7$ 5. Engelmann sprufe $\quad 33,47$

weevil.

6. White pine weevil. 33,48

7. Nortbern pine weevil. $: 33,49$ 8 . Schwarz's pine weevil. 33,50

9. Canarian pine weevil. 34,51 10. Southern pine weevil. 34,51 11. Deoklar weevil. 34,5

12. California pine weevil. 34,53

13. Yosemite pine weevil. 34,53

14. Webb's pine weevil. 34,54

15. Monterey pine 34,55 weevil.

16. Nouglas fir weevil. $\quad 34,56$

17. Ribbed pine weevil. $\quad 35,5 i$

18. Fiske's spruce weevil. 范, 59

19. Black spruce weevil. $\quad 35,59$ 20. Reil spruce weevil. $\quad 35,60$ 21. l.odgepole pine 35,40 weevil. 22. Color a d a bark- 36,60
weevil.

23. Arctic bark-weevil 36, 61 4. Jake Superior hark- 36,61 weevil.

25. Burke's fir weevil. $\quad 36,62$ 26. Piper's fir weevil. $\quad 36,62$

27. Balsam fir weevil. 36,63 28. Fraser fir weevil. $\quad 36,63$

29. Kandall's pine weevil. 37,64 30. Currit's bark-weevil. 37,65

Classifleatlon of the Genus Pissodes, Showing Technical and rommon Names and Sperles Numbers. (Original.)

This diagram will ensble the reader to reler at once to the technical and conmun names of any species number mentioned in the text, and will show at a glanee the position and relations of the divisions, gubdirisions, sections, subsections, series, subseries, minor series; snd speries into which the germs is divided. 


\title{
TECHNICAL PAPERS ON MISCELLANEOSS FOREST INSECTS.
}

\section{CONTRIBUTIONS TOWARD A MONOGRAPH OF THE BARK- WEEVILS OF THE GENUS PISSODES.}

\author{
By. I. I) IIOPKINS, \\ In ('hurge of Forest Insect Inrastigations.
}

INTRODUCTORY.

The bark-weevils of the genus rissols represent an important class of encmies of pine, spruere, and fir trees. For this reasone, in the future munagement of ferteral, stite, and private forests there will be a temand for information on the species and on practienl methods of preventing or redueing the damage from their attacks. Ineretofore comparatively little has been known alsout the Vorth

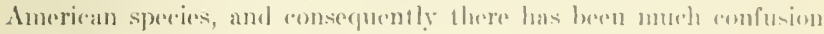
in collections and in publisherl information, due to the posiesion

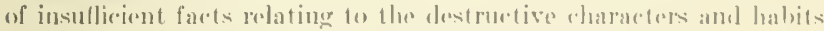

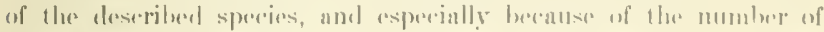

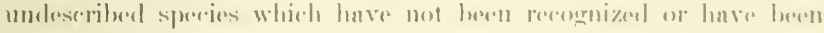
wrongly ialentified.

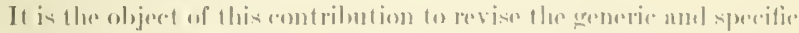

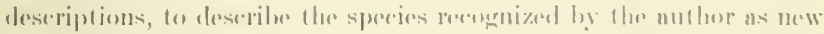

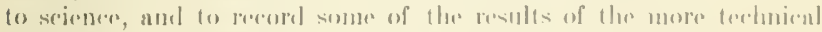
fentures of the invertigntions. This is pult of : 1 monterefipt on the

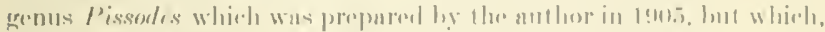

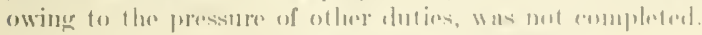

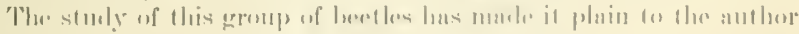

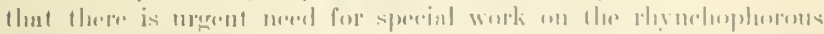

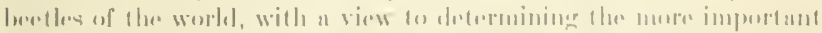

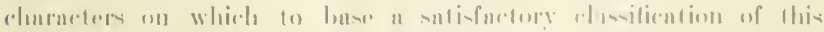

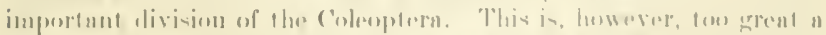

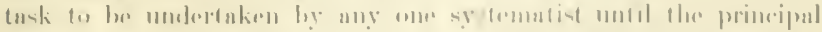

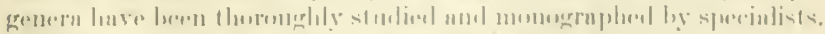

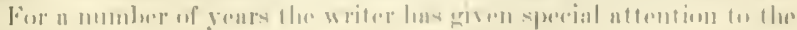

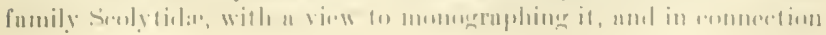


with this work the genus Pissodes has been studied in some detail and many other genera of the Rlyynchophora and other Coleoptera have received attention in order that a broader knowlerge of the order, and of the division to which the Seolytide belong, might be acquired, but there has been no idea of specializing on any but the Scolytide and possibly a few genera, like Pissoles, which are of special interest in connection with forest entomology.

The material which has served as a basis for this bulletin is that colleeted by the writer hetween 1890 and 1902 , that eolleeted by him and by the assistants in forest inseet investigations, Bureau of Entomologr, between 1902 and 1907 , and that found in the collections of the United States Department of Agrieulture and United States National Museun, espeeially in the Huhbard and Schwarz collection. Studies were made also of good series of specimens of 5 European species sent to the Bureau through the kindness of Dr. R. I Ieymons and Prof. H. Kolbe, of the Royal Zoological Museum of Berlin, and 3 European species represented in the United States National Museum collection.

The abbreviations adopted in this publiation in reforring to material in the different collections examined and that identified by the writer are as follows:

D. A.-Division and Bureau of Entomology, United States Department of Agriculture, Washington, 1). C., other than Hopk. U.S.

Hopk. U. S.-Branch of Forest Insect Investigations, Burean of Entomology, Inited States lepartment of Agriculture, Washingtou, D. C.

Hopk. W. Va.-West Virginia Agrionltural Experiment Station, Mlorgantown, W. Ta.

U. S. N. M.-United States National Museum, Washington, D. C.

II. \&.S.-HI. G. Hubbard and E. A. Schwarz collection in the United States National Museum.

1. M. N. II.-Ameriean Museum of Natural History, New York, N. Y.

The author desires to acknowledge in this connection the assistance of Messers. W. F. Fiske, II. E. Burter, and J. I. Webh in the collecting of material and recording of focd observations, to Messrs. C. B. Dyar and E. J. Krans for assistance in compiling the bibliography, and to Mr. .l. F. Strauss for assistance in the preparation of the illustrations.

\section{HISTORICAL REFERENCES.}

The name Pissoles (pitchecolored) was first preposed loy E. F. Germas (1S17, p. 3.10) without description, but to include Rhynchanus bufo Fub., Lirus nototus Fub., ant lihynchemes pini L. Later (Germur, 182.1, pi. 316-319) he described the genus, part of which was based on the month parts of Pissodes pini and $P$ '. notatus, hut anong the 10) speciess described only one, I'. nemorensis, has been retained. $\Lambda$ ropy of the original iescription of the gemus and of this species follows: 


\section{COPY OF ORIGINAI DESCRIPTION OF THE GENUS.}

\section{PISSOLES. Genus novum. ${ }^{a}$}

Character gencris.

[p. 316] Rostrum thorari subaequale aut longius, teres, ecrobe sensim subtus flexa. Antennae pone medium rostri insertae, breves, funiculo spptemarticulato, articulis subaequalibus. Oculi distantes, immersi. Thorax subtus integer. Scutellum distinctum. Coleoptera oblonga, abdomen et alas nbtegentia. Pt'des fortes, sub [r. 31i] aequales, tibiis apice unco inflexo armatis, tarsis brevibus, latis, artirulo penultimo bilobo.

Pissodis corpus oblongum, obscurum, maeulis squamosis variegatum. Rostrum thoraci subaequale aut longius, tenue, arruatum, teres, apicens versus planinsculum, scrobe lineari, sensim subtus fexa, basi rostri subtus connivente.

Antennae pone medium rostri insertae, breves, fractae, scapo recto. parum clavato, funiculo septemarticulato, articulis lenticularibus, 1. 2. sublongioribus, wbeonicis, clava ovali.

Caput parvum, rotundatum, oculis rutundis, lateralibus, immersis.

Mandibula valida, cornea, trilentata. Maxilla membranarea, intus biloba: lobo majore ovato, riliatu, denticulato, altero parvo, ensiformi, basali. Palji quatuor aequales, conici. Glossarium corneum, oblongum, basi angustatum, intergerio parso, basali, ciliato. Inveni instrumenta cibaria in I'. pini et P. notato.

Thorix transwersus, convexus, apice subito angustatus, coarctatus, subtus pone gulam leviter emarginatus, (anali pro receptione rostri mulle praeditus.

Scutellums distinctum.

Coleoptera basi thorace parum latiora, oblonga, convexa, postire rallosi, apies rotundata, alodomine laud breviora, alas obtegentia.

[p. 31S] P'reles fortes, subarquales, antici approximati. Femora clavata, plerumque dentata, thile parum 'ompressi', apice intus angulatis, extus unco magno introrsum flexo armata, tarsi loreves lati, artivulis 1. 2. trigenis, penultimo latiore bilobo, ultimo clavato, biunguiculato.

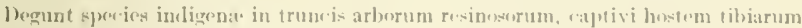
unco arcte (')mplectuntur.

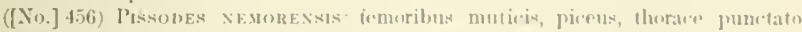
rugoso, punctis duobus allis, clytris fulvo-subfasciatis, macula infra medium alla. Irabitat in Ameriea lonerali. (Kentucky.)

Affinis corte P'. neta(o, paullo minor es macula clytrorum alloa apiri propius. Ros-

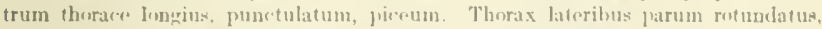

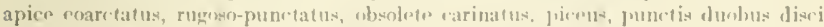

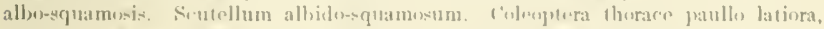

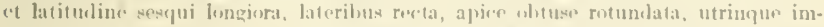

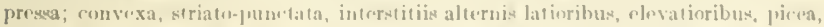

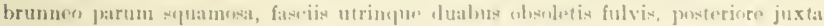

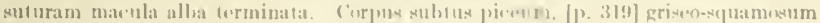

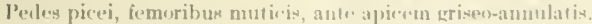

\section{[TRANSLATION OF ORIGINAL DESCRIPTION.]}

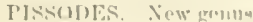

Cieneric characters. Beak not quile ne lonter or lomere than the

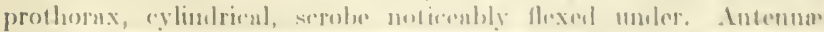

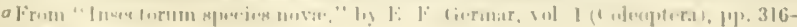
$31 \%, 1421$ 
inserted behind the midlle of the beak, short, funiculus 7 -segmented, the segments subequal. Eyes separate, sunken [impressed]. Thorax entire below. Scutellum distinet. The elytra oblong, covering the abdomen and wings. Feet strong, subequal, tibix armed at apex with an incurved hook, tarsi short, broal, the penultimate segment hilobed.

The body of Pissodes is oblong, obscure, variegated with spotcoveres suales. The rostrum not quite equal to or longer than thorax, slender, curved, eylindrical, somewhat flattened towarl the apex, serobe linear, noticeably flexel moler, in close approximation to the base of the rostrum below.

Antemne inserted posterior to the midalle of the beak, short, elbowed, seape straight, somewhat "lavate, funiculus 7 -segmented, the segments lenticular, 1 and 2 somewhat longer, obconieal, elub oval.

Ilead small, rounded, eyes romul, lateral, sunken [margin impresied].

Mandibles strong, comeous, triklentate. Maxilla memloranous, bilobed intemally: the larger lobe ovate, ciliate, denticulate, the other small, ensiform, basal. Palpi four, equal, conjeal. Glossarium [labium] rorneous, oblong, narrowal at base, intergerium [ligula] small, basal, ciliate. I have examined the mouth parts in $P$. pini and $P$. notatus.

Thorax transverse, convex, the apex slightly narowed, coaretate, slightly emarginate below hehind the gula, not provided with a canal for the reception of the rostrunt.

Sentellum distinct.

Elytra slightly broader than the thorax at base, oblong, convex, posteriorly calloused, romuled at apex, not shorter than the ablomen, covering the wings.

Feet strong, subequal, appleximate anteriorly. Femora clavate, frepuenty dentate, tibixe hardly compressed, amerulate interiorly at the apex, exteriorly amed with a hage hook flexed inwaral, tarsi

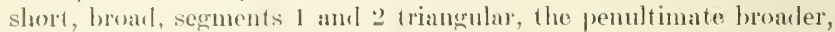
bilobeal, the last chave, with two raws.

The indigenous spereses live in the trunks of resinoms trees; they are able to hold on to the host hy the aurved hook of the tibia.

[Xo.] 456. Piskones Nemorkssis: Femora shortened, piceous, thorax ruerosely punctalc, whls wo white spots, elytra sublasciate with yeltow, a whitespot below the midale. Lives in North America. (lientuky.)

It is cortainly similar of $P$. uotatus, a little smaller, and the white spot of the rlytra near the apex. Benk longere than the thorax,

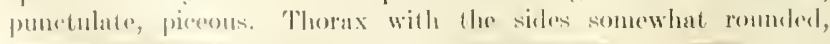


coarctate at apex, rugosely punctate, obsoletely carinate, piceous, with two diskiike spots of white seales. veutellum with white scales. Elytra slightly broader than thorax and half again longer than wite. Sides straight, obtusely roumled at apex, mupresserl at either side; convex, striato-punctate, the alternate interspuces broader, more elevated, piceous, lightly clothed with brown scales, each with two obsolescent fulvous bands, posteriorly close to the suture terminated witlı a white spot. Body piceous helow, with gray scales. Fcet piceous, the femora shortened, annulated with gray before the ajpex.

Following are the names of the other species clescriberl and the genera and species to which they were later referred.

Yo. 457. P'issodes macellus = IIylobius pales Boh., Sch. ('ur'., II, 340.

No. 45s. I'issodes choieus = Ilitipus choicus (Germar).

So. 459. Pissodes onychimus = Hitipus onychinus (Germar).

So. 460. I'issodes flommiger-Ililipus flammiger (Germar).

No. 461. Pissodes picturatus = Milipus picturatus (Crermar).

No. 462. Pissodes polymitus= Hilipus polymitus ( ( iermar).

No. 463. P'issodes erythrorleynchus = Hitipus erythrorhynchus (fiermar).

No. 164. Pissorles prodigialis= Kilipus prodigialis ((i'rmar).

No. 46.5. P'issodes trachypte mus = llitipus trachypt mus (Germar).

Schoenherr (1,26. PJ) 2.25-2.2(i) was the first to sublivide the genus and to designate l'issodes pini (L..) as the type and $I^{\prime}$. pice if (Ill.), P. horeynis (IJorlst) I'. motatus (Fab.), I'. piniphitus (HJerbst), and $l$ '. memornesis Germ. as atypes. 'Therefore, aceoreling to the rules of nomomelature (stiles, 1905, J'1). 26-27), l'issostes pini (1.) must staud as the tran of the gerusus.

It appears that up to 1909 the genus was reprexented ly 21 authentically recognized speries, 7 from Vorth Imerica, ! from Europe, 3 from castern siberia, und 2 from dapan, as follows: 
旨

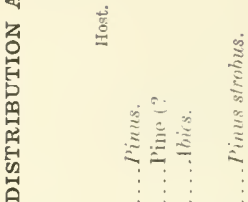



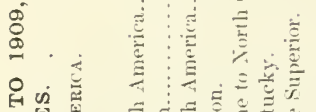

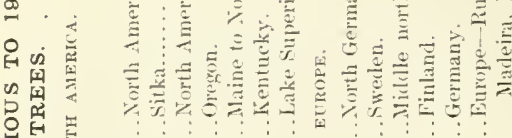

要

号

幽

n

叟

on

14

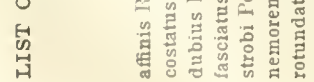

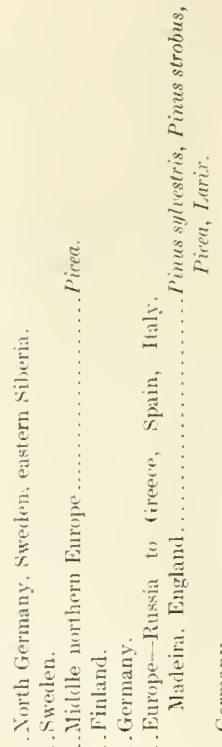

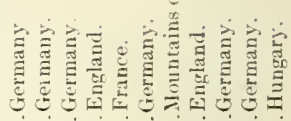
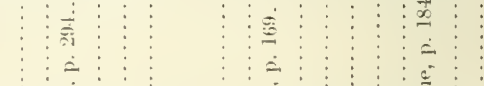

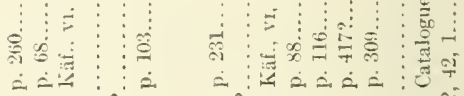

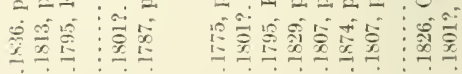

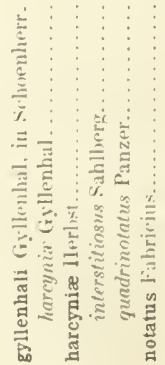

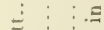

$\Xi \vdots \vdots \vdots 0$

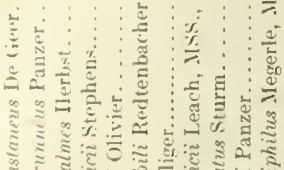
है. मूँ 

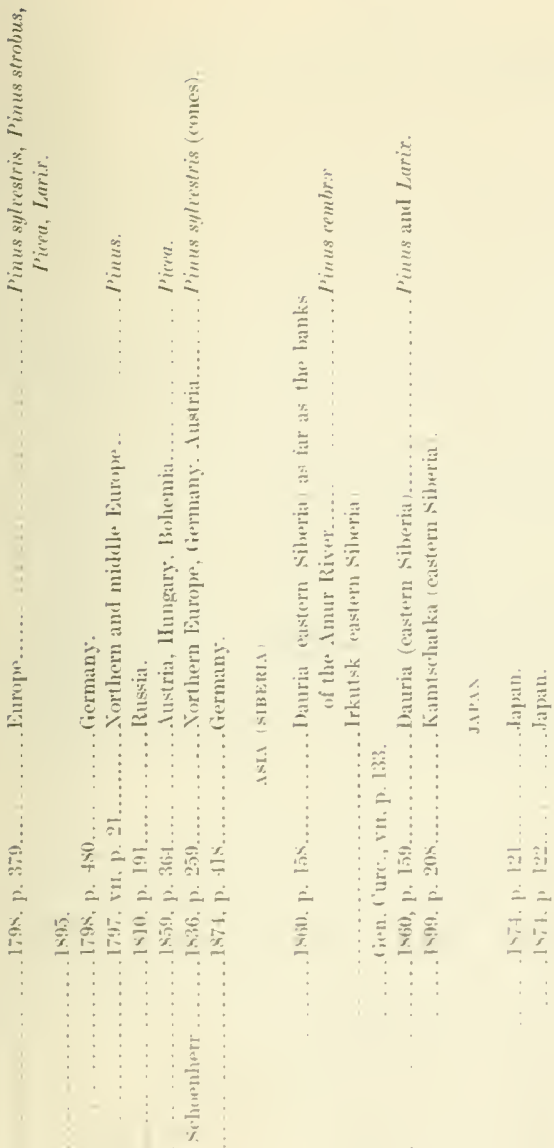

$i=\quad \ldots \quad \vdots$

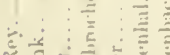

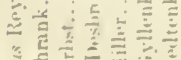

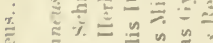

ㄴ.

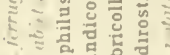

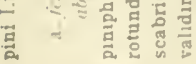

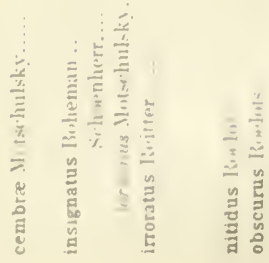

$5793 ; 11$ 


\section{TAXONOMY.}

\section{CHARACTERS USED BY DIFFERENT AUTHORS.}

Beginning with the second division of the Coleoptera or suborder Rhynchophora of most of the authors, the prineipal characters compiled from Lacordaire (1\$63), Le Conte and Horn (1876), Ganglbauer (1903), Kolbe (1903), and Bedel (1SS6-1SSS), which led up to the family ('urculionidae may be summarized as follows:

SIBORDINAL ANI FAMILY CHARACTERS.

Heal prolonged into a beak; maxillary palpi rigid, 4-jointed, without palparium (see "Revisional notes," page 9); lubial palpi 3-jointed; labrum absent: gular sutures wanting; prosternum with epimera extending across the base (see "Revisional notes," page 9); testicles globular: abdomen always with 5 (visible) ventral segments (see "Revisional notes," page 9); tibire without movable spines; pygidium dividul (soe "Revisional notes," page 9); elytra with strong fold toward inner edge; tarsi dilated, brushlike beneath, third joint bilobed, fourth obseure; mandibles without aecessory pieces; antenne genieulate, elubbed; beak more or less curved.

Continuing through the family (urculionila, the principal characters, adopted by one or more of the authors mentioned, which lend uj) to the subfamilies, tribes, or groups to which the grenus Pissodes was referred, are as follows:

TLIBAL INI) S[BFAMILI ("IIARAC'TERS.

Latorclaive (1s(i3, plo. $142-464)$ : Mentum leaving maxilla exposed; submutum forming a peduncle; muterior coxa usually contiguous; pyegidium coverul by the olytra; metasternum more or less clongate; motopistermum at least moderately hroal: antemal fumiculus 7-jointerl: beak variable, with antenual grooves; mescpimerum not asconding towarel base of alytra; protherax with anterior ventral margin ustally (manrginate. Tribe Ilylobiides.

Tarsal claws free; elytra with elevations at hase; mesepimermm usually larere; body oblong, oval. Croup Itylobiiles.

Le conte and llorn (1856, P). 122, 137): Tibiar with tooth of outer apical angle small: eres not contiguous henualn; mandibles with 3 teeth: sicle pieces of motatlumax clistinet: lateral angles of first rentral segment not visible; mentum transverse; labial palpi largo. Tribe 11 yobini.

Stierlin (184i3, p. 403): Tibia compressed; inner edge bisinunte with apoul lonk. Subfamily Ilylohimi.

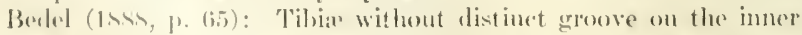
elge, but with an incurved apical tooth; rentrul somgments 2 and 4 
with straight sutures; anterior cosa separated, but without groove for beak; tarsal elaws small. Tribe Pissodini.

Nüsslin (1905, f. 110): Beak with antennal insertion near the middle. Subfamily Pissorlini.

\section{REVISIONAL NOTES.}

\section{GEXERIC CIIALACTERS.}

The anterior ventral margin of the protloorax is not slichty cmarginate in any of the speries examined hy the writr. Ther reference to a dentate femur was hased on the species of Ilytobius am IItipus. With these exceptions, the original cleseription applies very well to all of the known species.

\section{STBORIIXAL, IXI FAMILY CHIRACTERS}

There lias bern consildrable diflerence of opinion among systematists as to whether the palpus should be referred to as t-jointed or 3-jointerl.

It is evident to the writor that the lnterul segment of the nuxilla, which has leen mistaken lor the basal joint of the palpus, is homologess with the palpifar in other ('oleoptern amel orders of inseds, and it would serm, therofore, that the rigid, 3-jointed palpi should be recognizel as one of the importunt charncters to distineruish the true Rhyouhophora from the oflier Coleojern. It would remove the Anthribilar and some of her rroups which, on account of the ubsence of gular sutures, lave leen placed with the Rhynehophorn, hut the writer is inclined to agree with some recent nuthors thut these really (a) nost bolong in the Rhynchophorn. Ju representatives of the ('ureuliomica', foolyticla, and seseral other fomilies examined by the writer, the maxillary pulpus is distinctly 3-jointerl. In some, ns in Pisseress, the palpufor chosely resembles a basal joint of the pulpus, but it joins the stijes and the apex aloes not extend beyond the luase of the galea. Tluerefore it enu not belomer to the palpus, but is the part of the lowly of the maxilla to which the palpus is attached, desicrmatoul as the palpifor.

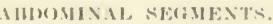

The ablominul tereriles 7 and 8 luse been referred to by rarious

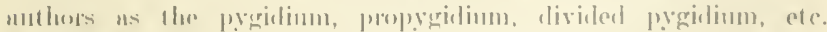

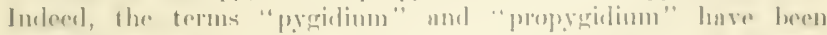

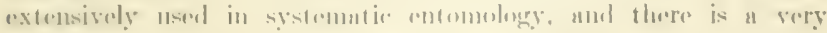

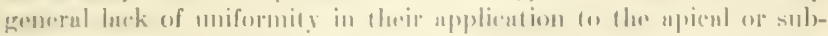

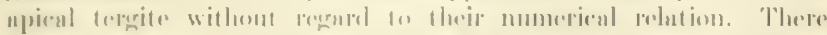

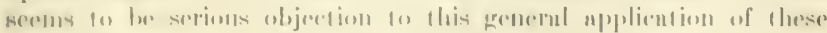
terms in elassilention, from the fuct that in ermpurative muntomy 
they hatre no meaning. "Therefore in the use of the terms "prgilium" or "propygilium" it is important that the numerical position of the tergite should be mentioned.

In the Cureulionicla, for instance, tergite 7 of the female occupies the pygal position, while tergite $t$ of the male occupies the propygal position, and tergite $\&$ the pygal. In the Curculionilax, Scolytida, and many other Coleoptera abdominal tergite $\bar{i}$ is by far the most important of the series, owing to the fact that it presents important characters of strueture, seulpture, stribluating accessories, sex, ete. (soe Plate lit).

There is also some confusion with reference to the abrominal sternites, or ventral segments. The 5 segments often referred to as the first to lifth are the sternites of the third to serenth aldominal segments, the first and second being olseured by the coxal ravity (Hopkins, 1909, fig. 3S). Therefore they shoukl be reforred to cither in their proper numerical order or as the 5 visible ablominal sternites.

\section{REVISED CLASSIFICATION.}

It appears to the writer that it would contribute to a more convenient and natural arrangement if we would give the Curculionidae of most anthors the rank of sujerfamily, and thus promote the old subfamilies and tribes to families and sulffamilies. 'Thus the genus Pissodes weruld fall in the superfamily ('urculionoiden, family ('urenlionidar, atal sublanily l'issolinx.

The subfamily P'issorlina woukl come next to the group of genera comprising the subfumily Ifylobiine. The two subfamilies are rharactorizod as loullows:

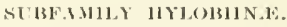

Anteriof coxar contignous: prothorax with anterior ventral margin rmarginate and produed toward the sides; beak stout, with antenmal insertion in front of midhle or toward the tip; eyes oval; tibiar wifhout tooth on imner apical angle. Ther North American grenora of this sulf family are distinguished as follows:

1. Medaternum very short.

i'aroplinthus.

II. Metasterunum loner.

A. 'Tilise with outer atpie:al angle dilated .

I'achylobius.

13. Tihise with ontor apical angle not dilated.

at. 'Tibiar commonly narrowed fowart tip. llitipus.

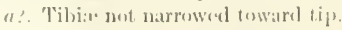

b. Fenerat not toothed. Ilypomolyx. livelocimus.

b?. Femorat tomberl llylnbius. 
STBFAMIIT PISSODIY.E.

Anterior coxæ slightly separated: pothorax with anterior ventral margin not emarginate or produeed towarel sides: beak usually slender, with antennal insertion at or loward mikldle: cyes rounded: tibire with tooth on inner atpical angle.

Metasternum long, femora not tonthisl.

Pissodes.

\section{SLBORDINAL TO SIBFAMHLY CUIRACTEISS.}

Head behind the eyes without gular space: maxillary and labial palpi rigid, 3-jointed: labrum wanting or obscure.

suloreder lihvnchephora.

Beak or rostrum prominent; elytra with luteril fold or croove: abilemen of sexes with different number of tergites (s in the males, 7 in the fentales); tarsi with fourth joint obseure, third bilubed, ventral surface of first to third donsely alothed with fine relvety hairs, fifth joint with simple claws . . . . . . . . . . . Superfamily ('urculionodideis.

Gular perlunele (submentum) usially lones antenna 11-jointed,

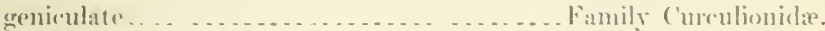

Protlorax with anterier ventral margin not distinetly emarginate; tibix with incurvel alpical tooth: fomora unamed; anterior coxa not widely separated; ablominal tergites cosered by the elytra;

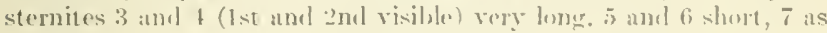
long as is and li cogother: "yos romeded, widely separated.

sulfomily l'isserlinas.

\section{HFNERIG HIIRM"THES.}

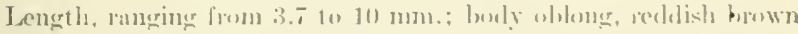

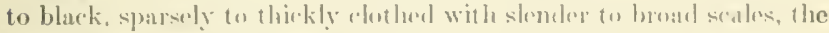

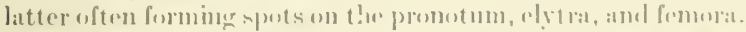

Pronotum varialble; brosder than loner, rarely as longe ac broad,

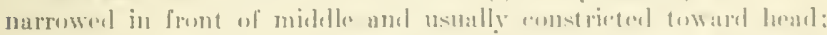

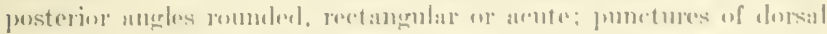
surfure with intervening flitt or elevated contiguens spanes which sonetimes wherere the punetures.

Elytre variable, more than as long aguin, with the hase as hemel or

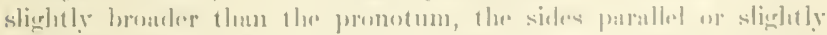

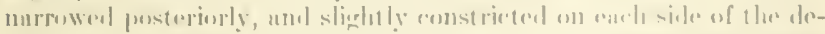

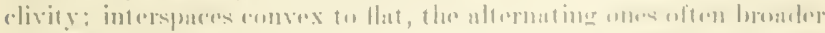

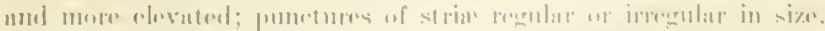

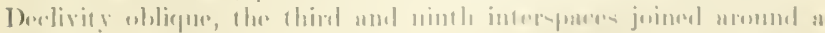

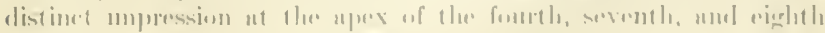

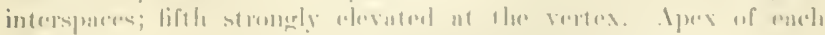

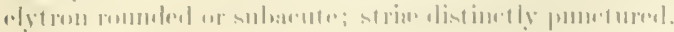


Head (figs. 1, 2) behind the eyes globular, about one-half maximum widtle of prothorax, smooth, punctured, slightly impressed between the eyes and with a few seales on the front toward the margins of the eves.

Beak slender, eylindrical, punctured, as long as prothorax or longer, with sides parallel or slightly narrowed toward middle, or slightly broader toward hase of mandibles. Antennal insertion at or toward middle and the antennal groove beginning just in front of insertion and extending almost parallel with ventral margin to near eyes.

Antennæ (fig. 1).- Scape shorter than funiele, which is 7 -jointed; first joint about as long as seeend and third together; second to serenth of about equal length, but slightly increasing in width towari chub; first joint of elub large, nuch longer on one side, and sparsely elothed with short hairs and long bristles; other joints of elub slightly more flattenerl on one side, more densely elothed with fine hairs, and the sutures as shown in figures 1 and 2.

\section{ANATOMICAL DETAILS OF THE ADULT. $a$}

TIIE IIFAII.

The generic rharacters and anatomical details of the extemal skeleton and appendages of the head are shown in figures 1 and 2 . When compared with the head of a seolytid beetle (figs. 3,4 ), it is plain that the subordinal waracters are common to both, but further than this there are certain features which at once refer them not only to different fumilies but, in the writer's opinion, to different divisions of at least superfamily rank.

Mouth parts. - The labrum and elypeus are not represented, and the "pistoma is unly represented extemally by a smoother area faintly defined by an obseure line and lateral bristles. As usual, the lateral ancres, or area, support the dorsal artieulation of the mandilules. The hypostoma also is olscurely defined externally, but is represented by the thickened declivous anterion maremin of the rentral wall of the beak, by the sides of the submentum, and by a semewhat irregular apoleme, the anterior angles of which support the vent ral artionlation of the mandibtes, the midelle supporting the maxilary arde, the inner anterior angle produced along the lateral area of the submentum, and the pusterior angle ending just beneath the latge lyyostomal puneture. Thus the hypostomal area is that part of the fontral wall of the restrum which lies anteriog to the indistinct limit of the pregula. The pleurostoma is represented by the convex aru

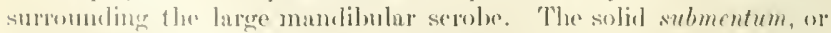

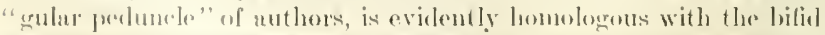

"f for anatomical nemmelature, sore Technical Serieg 17, l'are I, Bureau of Entomology, I. S. In+ph, of A"rieulure, 1909. 
submentum in Dendroctonus. Its apex is truncate or rounded, and supports the labium, the menturn of which is about as long as the

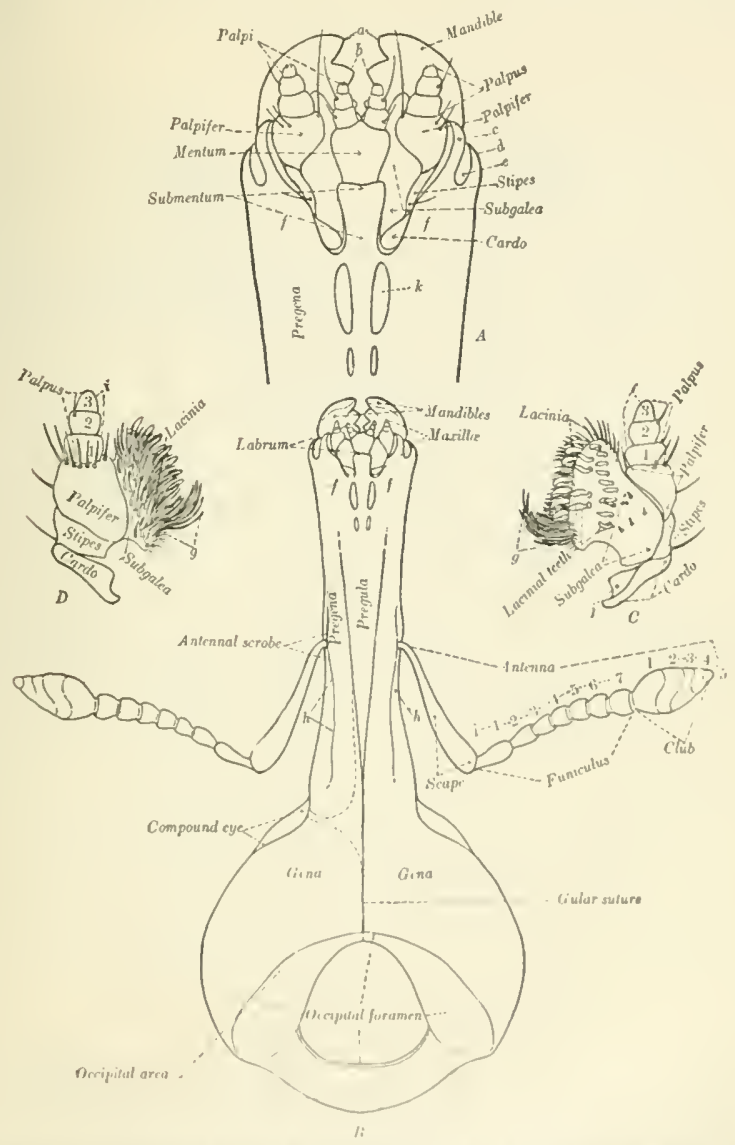

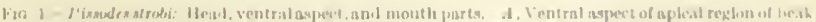

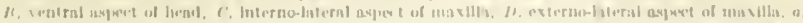

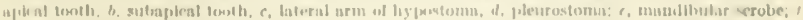

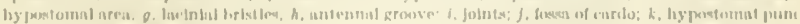
tiare Inther's Illuytratlon.

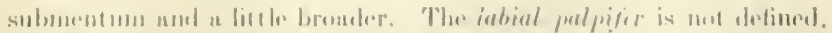

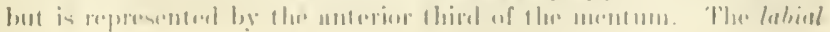


palpi are stout, conical, and 3-jointed, and not so long as the mentum, the first and second joints of about equal length and the third short.

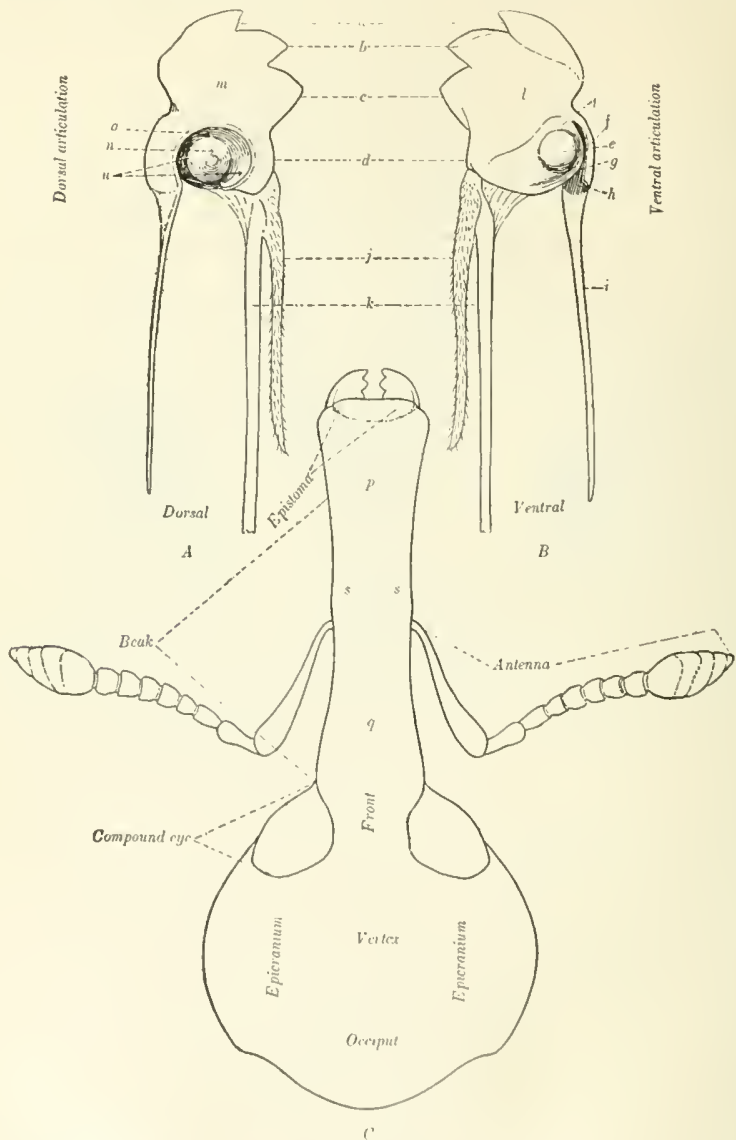

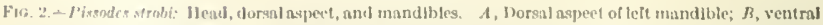

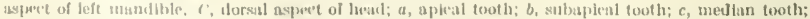

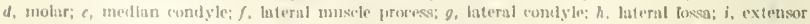
tenton; j, plaryngesl bra on; $k$, retrator tendon; $l$, ventral area; $m$, dorsal area: $n$, median contyle:

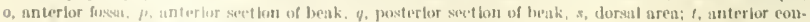

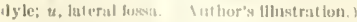

The lignta is marrow and elothed with tomer bristles rising from the

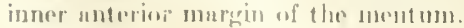


The form and relative propurtions of the maxille are shuwn in figure $1, C, D$, and in place in $A$. The cardo is shurt and stout, and articulates with the hyporstumal apuleme. The extensor. flexor, and other muscles of the cardo, maxilla, and labium are attached to the

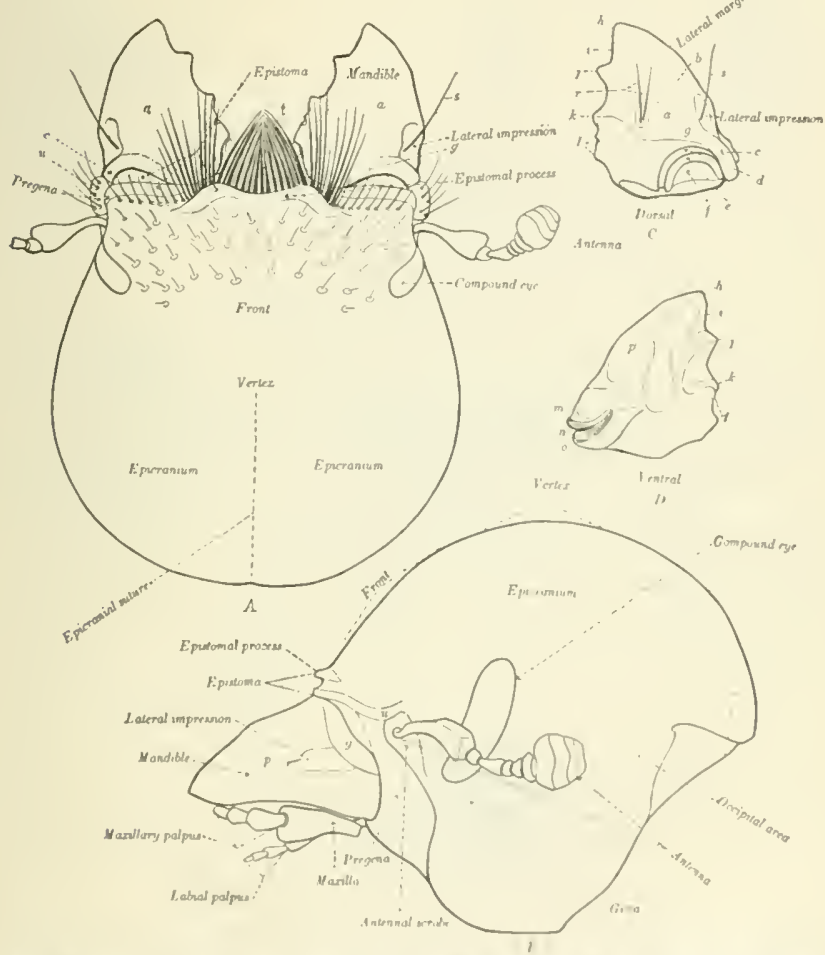

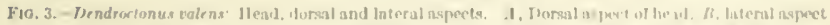

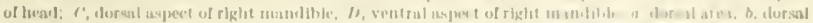

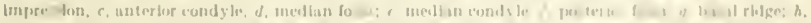

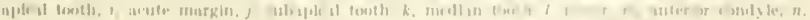

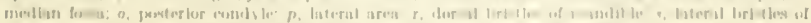

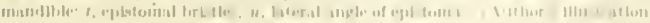

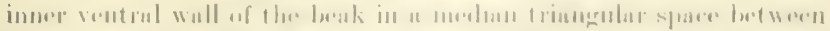

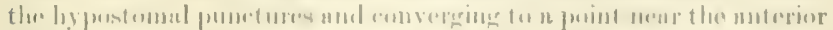

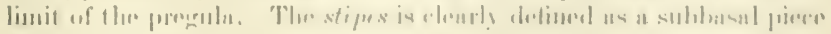

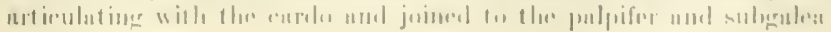


by distinct sutures, and in this respect is rery diflerent from that in Dendroctonus, in which it is fused with the palpifer and subgilea. The maxillary palpifer is large and stout and from an interno-lateral

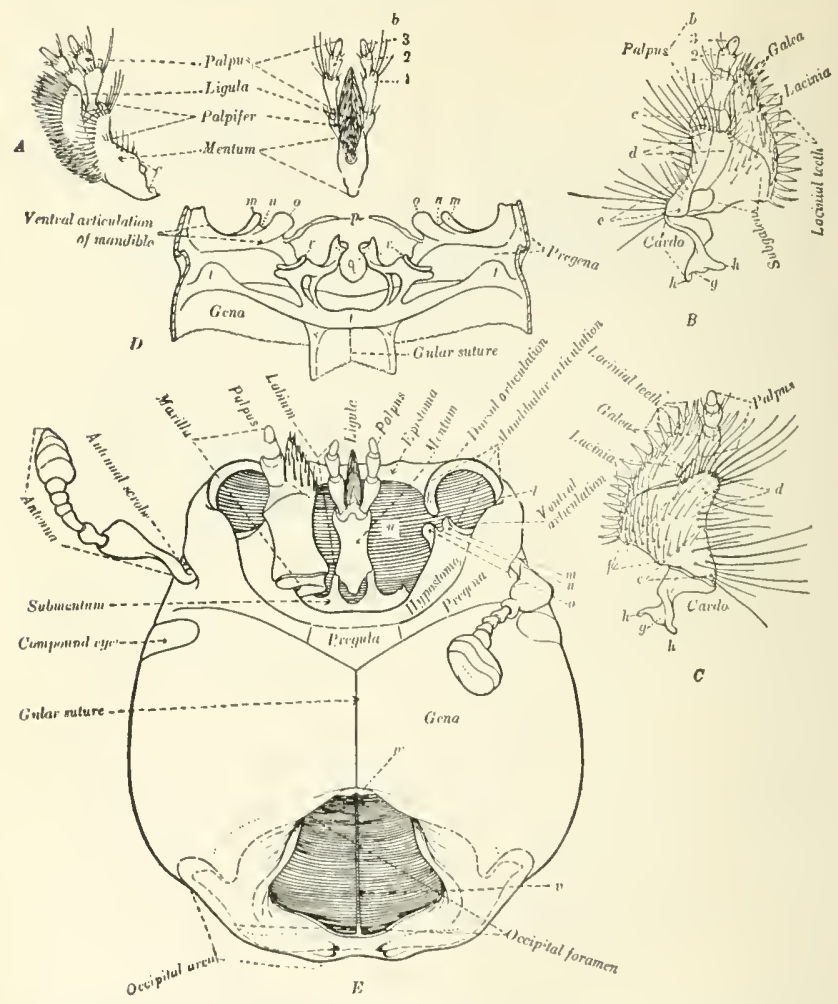

Fu. 4. Dindroctonus valcre: lleal, vental aspect, and month patt. A, Lablum; $B$, maxilta, internoluteral aspeet: $r$, same, externo-lateral aspeet; $l$, lyypostomul regton, dorsal aspect; $E$, head, venfral aspect, $a$, hasal fossia of mentum; $b$, joints; $c$, basal membrane; $d$, jafjeferal area; $c$, stipal area; $f$, sub. fatleal area; 9 , lossa; $h$, musde processes; $k$, median condyle; l, lateral fossit; $m$, anterior condyle; $n$, medhan fossa; $o$, posterior condyle; $p$, hypopharyngend bracon; $q$, sulumental process; $r$, maxillary con.

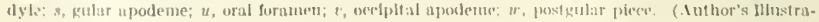
(lon.)

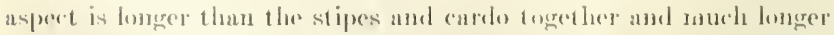
than the malpus. It is separated from the sulugralen and stipes loy dist inwt sutures, mol wesembles an very large first joint of the palpus. 
The subgalea, gatea, and lacinia are represented by one broal lobe without even the indieation of sutures separating the lacinia from the subgalea as in Dendroctonus. The interno-lateral face and internal margin of the lobe arearmed with stout lacininl teet h, while the externolateral face is elothed with bristles and hairs, those of the posterior angle being very long and eurved. The palpus is stout, ronieal, 3-jointed, shorter than the palpifer, joints 1 ant 2 of about equal length and 3 shorter.

The waracter of the mandibles is shown in figure 2, 1 and $B$. They are stout, subrectangular, and without a sear on the "outer surface." The inner edge has 3 promineut teeth; the apieal, subapical, and median tecth are stout, triangular, and about equal in size, the molar not represented. The outer lateral areu is cleoply impressed at the base of the lateral muscle process, which is long and broal. The ventral articulation has a simple median "ball" condyle", while the dorsal articulation has a median "ball" condyle surrounded by a deep fossa. The extensor and retractor muscles are at arehed to the inner wall of the cranium, amd are connectod to the mandibles by long, very stencler, subehitinous tendons (fig. $2, i, k$ ). The pluaryngeal bracon is also long aud slenelere, and appurently subchitinous, thus serving as a rigid support or braw to the lateral wall of the pluarynx.

The eharacters of the antenna are shown in figures 1 mul "2. The scape is slightly shorter than the funiculus, and the club is ahout half as long as either one. The funirulus is 7 -jointed: joint 1 is about as long as joints 2 and 3 together; joints 2107 ase of about equal length and increase slightly in wilth soward the cluls. The clul, is subcrlindrieal, orate, acuminate, with apex subacute ancl wish is obscurely dofined joints. loint 1 is much longer on one side than on the other and sparsely alothed with short hairs and long bristles; the remaining 4 are alout erpunl in length, stightly more impresied on the anterior face and densely alof leal with fino hairs which olsenes the sutures; the sutures, aleoreling to the print of view, may be obligue, transwerse, resurved, or procurved.

The pregula is clearly defined in the ventral aren of the rostrum. The sutures diserere anteriolly from their junetion with the median

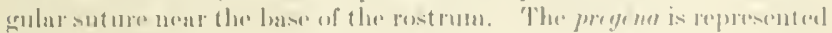

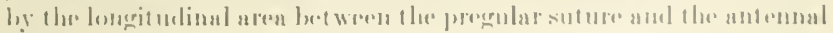
growe.

TH1: THIIR.s $x$

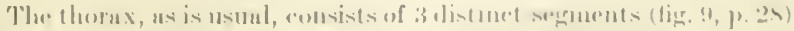
The protherax artieculates forety with the mesollomas, lont the mesothorax und metathorax are firmly connected. "The oombined length of the stermal areas of the there thoracie sements is slightly greater than that of the stermal aren of the alolomen, while the com- 
binerl length of the dorsal or tergal areas of the thoracic segments is also shightly greater than the tergal area of the abiomen. The pronotum is slightly longer than the mesotergum and metatergum together. The prosternul area is much longer than the mesostemal and about equal to that of the metastemal area. The metapleura show the same relative proportions as the sterna, and together are much longer than the abiominal pleura. The anterior dorsal margin of the pronotum is not greatly extended beyond that of the sterum, as it is in Dendroctonus; the posterior margin of the metatergum is but slightly extended anteriorty beyond the posterior ventral margin of the same segment, but it is much in alvance of the posterior margin of the metapleura. (For a discussion of the divisions of the thoracic segments of insects and of the nomenchature, see Hopkins, 1909 , p]. $23-35$.

The Prothorix

Is is usual in the mynchophorous bet les, the tergat, pleural, and sternal areas are fused into a continuous band. In addition to the preceding drseription of the monotum there is usually a median elevated line extenling from the anterior impression to the posterior margin, and each side of this line toward the mitdle there are two distinct inpressions filled with whitish or yellowish seales, thus forming clistinct subelorsal spots. There is also a broal, posterior, lorsal impression near the posterior margin. Tha laterat areas are usually marked with spots of stales, which are more or less distinct and variable in size and form. The anterior margin is usually evenly curved, but is sometimes slightly cmarginate. The anterior ventral margin is never emarginate of elistinetly produced toward the sides. The posterion dorsal margin is stightly hisinuate, and the pesterior and lateral declivities of the notum are vertical. The posterior ventral margin is elevated and uniformly corvol. The rpisternal and epimeral areas are not indicated by surlace seuptere, but the preepisternal aret is plainly iudieated by a transwerse clevation anterior te a distinet transerse plental groose. This groese also extends acrose the stemal area and thus alelines the presternal aro, which is strongly convex. Thr sternum is llat to sulocomox, subled livens, the posterior seetion tominating in an asute point betwern the coxit. The stermllum is represented by as small but distimet inter"oxul pirce and the poststemellum ("Ppine rum" of nuthors) by the marrow posterior area which incloses the coxal. The coxal envities are larere, with the immer morgins lout slightly separatorl.

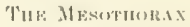

The mesothorax is short and partially hidken from riew hy the prothorax, which cosers the anterior thied of the stemites, ptentites,

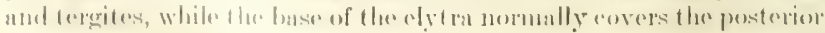


areas of the tergites, leaving only the scutellar process or scutellum exposed between the basal angles. This process is densely elothed with white or yellow seales.

When the prothorax and hlytia are removed the mesotergun is found to be rectangular in form; the proseutum is clearly defined as a convex strungly ehitinized notal plate, occupsing about two-thirds of the tergal area. The anterior margin is acutely enarginate and the anterior angles strongly produced. The mephragma is strongly flexed bencath the posterior dorsal area. The scutum appens to be represented by a narrow dowsal area between the merlian process of the seutellum and the posterior limit of the prescutum, and by the lateral submemlanums areas between the oblique lateral margin of the preseutum and the soutellum. The seutrllum is represented by the prominent merlian process and laterally by the chitinous piece just ponterior to the scutal area. The pestseutellum is represented ly the sulsontral and flexed marin of the seutellum and by a slendri lateral arm.

Mesopleura.-The episteruum, preepisternum, epimerum, and postepimerum are all elearly defmel. The propisternum is sinilar to that of lhendroctonus. It is nearly as large as the epistemum, narmond towarl the sterum, and very broad toward the opposite extromity, where it projerts overe the antorior dorsal andes of the

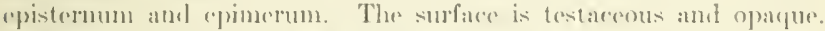
Its posterior mavin in clearly defined by a clistince but narrow lateral impression, which is densely alothed with fine whitisle seales. The anterior is strongly declivous, andare, sloming, and the prepisternal

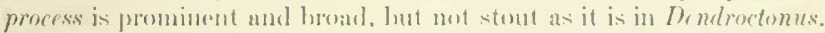
'The ablifue ventral margin is thickened, but the pesterior dorsal section is sory thin and without a distinct arm rommedting it witls the artionlating andyles. In this respert and in the strongly dubted

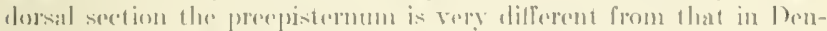

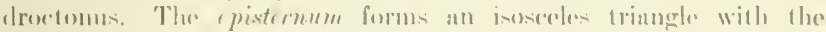

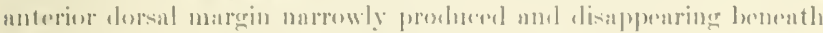
the dilated end of the prepepistermum. The vestral and posterior

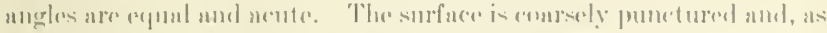

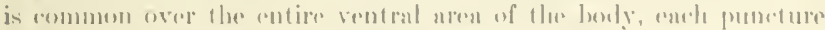

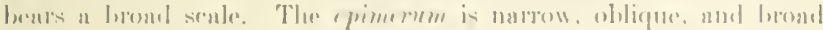

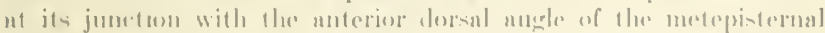

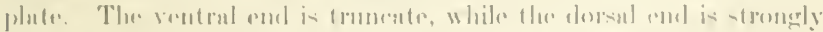

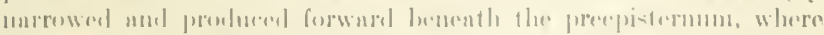

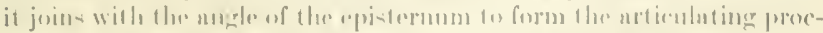

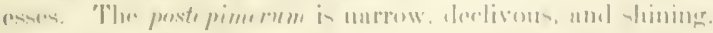

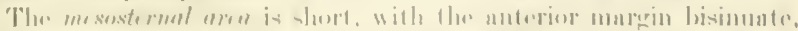

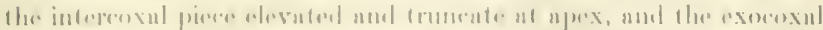

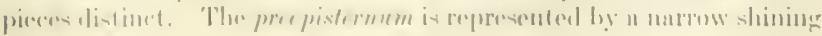


area, but the sternellum and poststernellum are not represented by extemal areas. The coxal cavities are not widely separated. The mesothoracic spiracle is large and situated near the ventral edge of the preepisternal process where it is covered by the prothorax.

\section{The Metathorax.}

The metatergum is quite similar in general character to that in Dendroctonus (Hopkins, 1909, fig. 20); it is shorter and broad, and the postscutellum is very short and declivous. The membranous area of the preseutum is broad. The dorsal band is narrower. The seutellar groove is hroad but less produced anteriorly. The metatergal costie are not elevated abore the scutum. The prescutal lobes are less prominent and the pleural hooks of the postscutellum are long and slender. Internally the median apodeme is more oblique and more arutely joined to the anterior apodeme. The longitudinal ridges formerl by the deep lateral impressions of the scutellar groove are much more prominent and continuous from the anterior apodeme to near the posterior margin. The basal area of the wing and the articulating accessories are similar to those in Dendroctonus, differing only in minor details.

The metapleura are also similar to those in Dendroctonus, cxcept that the episternum is narrower, the anterior ventral angle more produced and acute, the postorior end narrowed, and the exposed trinngular plate of the postepimerum longer. The chitinous area of the epinerum is narrow, while the submembranous area or postepimeral area is correspondingly broad. The pleural clavicula is very fong and the clavicle and coracoid processes are distinctly scparated.

The metesternal area is a third longer than the mesosternal and twice as broad as long, without a median longitudinal groove, hut with a median impression toward the posterior margin of the sternum proper. The sternellum is represented by an interoxal piece covered by the median process of the aldominal sternite, and flexwl beneath this is a plate which evidently represents the poststernellum. The coxal cavities are very large, widely separated, and suppress the first and second abdominal sternites. The metathoracie spiracle is situated in an open space between the metapleural clavicula and the mespepinerum.

TIE ABIXIES.

Tergites. - Tle nbdominal tergites increase slightly in length from tergite 1 (o) tergite 4, inclusive, and ulse become more uniformly subchitinous; is and of are shorter than 4 , and of is more membranous and hus a par of membranous lobes which are absent in the five prereding tergites; 7 and $x$ are elitinous and elothed with short hairs. The epiplemites me membranous and quite charly defined in living exumples. Thlor spirnele of segment 1 is very large, as usual, and the 
others diminish slightly in size to and inclueling the serenth. Spiracle 8 is evidently not representer. The character of abdominal tergites 7 and $s$ in the males and females of different species is clearly slown in Plate VI. It will be noted that they are quite different from the corresponding tergites in Dendroctonus, hoth in form and restiture. In those of Pissodes two or three hairs rise from each puncture insteml of one, as in llendroctonus, and in tergite $\bar{i}$ of the nale the middle section of the posterior margin is broully retuse, with the primeipal striclulating serapers on the subarate lateral angles. In the female the postrrior margin of tergite 7 is bronlly reumded. 'The semsory tubereles in tergite 7 of both sexes appear to be of considerible taxonomie inportance, especially in their number and arrangenent.

Sternitrs. - The characteristic form and relative propertions of the abdominal sternites are shown in fige. 9(p. 2s). The intereoxal process of sternite 3 (first visilile sternite) is broad, with a slightly produced acute apex. In addition to the description of the abdominal sternites on page 10, suture 3 (or the first visible suture) is bisinuate, with the middle section strongly curved forwarel. Sutures 4,5 , and 6 continue straight to the lateral marrin. The apex of sternite $T$ in the males is variously sculptured, as described in the symopsis of secondary sexual characters. Sternite 8 in the males (Plate IX, $f$ ) is small, separated in two sortims, and forms the so-callow genital plate, while in the females (Plate VII, e) it is solisl and evislently fused witl tergite 9, which is evidently represented by the chitinous rod on apodeme d, and the fork $j$.

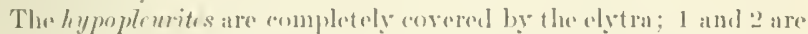
fused with the anterion end of :3. The sides of 3 and 4 are nearly vertiral and latw the dorsal ederes arote, to fit into the posterior lateral groose of the olytra: 5, 6, and 7 are oblique and increase in width to anel including 7 , the pesterior margin of whel is obliguely enrved to

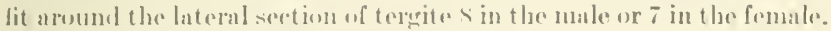

THE: WINGS.

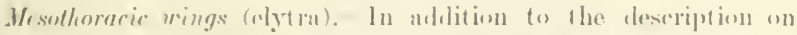

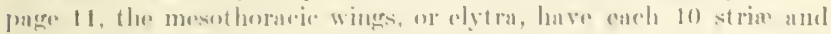
11 intersparese, the latter inclusling the costal and anat margins. The

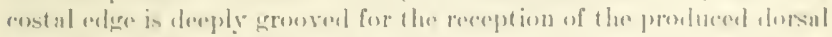

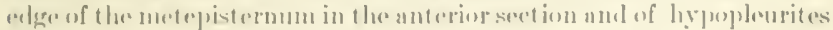
3 and 1 in the posterior sertion. Bopiming near the posterior end of this growse and extemding obliguely to the "pux there is a trinngular

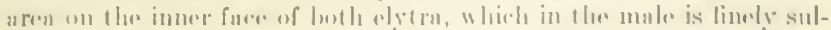

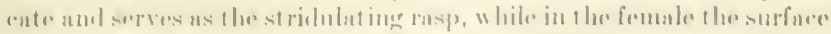

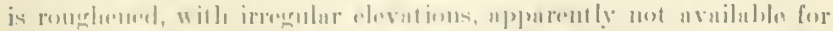

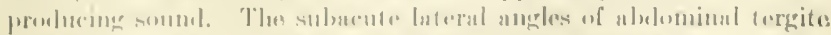
7 of the mule e ielently serve us the stridulatory serapers. 
Metathoracie wings. - The metathoracic wings are similar to those of Dendroctonus, but are at once distinguished by the two branches faintly connected with an evilent cross-vein between the media and culitus. The writer has not male a sufficient study of the modification of the veins in coleopterous wings to warrant anything more than the provisional interpretations indicated in the recently published figure (IIopkins, 1909, fig. 1).

\section{IXTERNAL INATOMY.}

The only parts of the internal anatomy that have been studied in detail by the writer are the reproductive organs of both sexes, which are of special interest, both from a systematic and from an econmic point of view. These present taxnmomic characters of last resort in the determination of the species. Those of the female are of interest from the fatet that it is elamed that indiviluals must at tain an age of several months before the ovaries are sufficiently miturecl for the development of eggs; also, that a single copulation may suflice for a long period; therefore it is important in our economic studies to be able to readily recognize the sexes and the approximate age of specimens collected at dilferent times. The details of the male reproductive organs are shown in Plates VIII to XI, and recpuire little explanation in addlition to that given in the legends and synopsis. It will be seen that there are specific dilferences in the main lorly or stem (Plate XI), as well as in the fork (Plate X). The organs of reprouluction in a very young female are shown in Plates VII and VIII, the parts of which are fully explnines in the legends.

The profile of thr abdomen (Plates VII and IX, I), with the parts in situ, shows the relation of the rentral and dorsal segments and genital plates to the different parts of the reproductive organs, certain parts of which are evidently direct molifieations of the ninth and tonth dorsal and ventral somments. The figures are intended to illistrate the main features and are in some respects subeliagrammat iral.

SECONIIRY SEXIAL, CHARAC"IERS.

Frmales. - In the females there are but 7 visible abchominal tergites, the righth being completely covered by the seventh, which forms the pregritium. The boak is longer, smonther, and more slenter than in the males. The apical or seventh aldeminal sternite is ustally shorter than the two preceding sternites together, which are usually

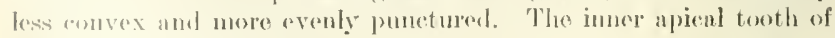
the tibian is alse smmaller.

llotes. In the males there ne 8 visible ablominal tergites; the sevend is distingulishen ly the broully retuse posterior margin,

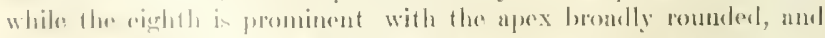
forms the pyeglium. The abdominnt sternites is and it are more con- 
vex than in the lemale, less evmly punctureal and more shining toward the mildle. The beak is stout, shortor. lus shimine and mores distinctly punetured. The inner ajucal toutle of the tibia is ustrally. more prominent.

\section{THE EGGS.}

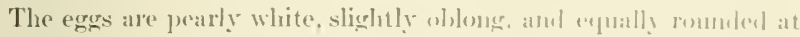
both ends.

\section{THE LARVA.}

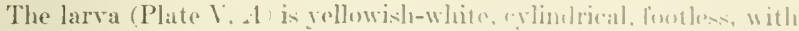
3 thoracic and 9 distinet abdominal segments. flo anal hobes representing the tentl: the thoracic segments not alistinetly laror than the first ablominal. The hairs of the second prothoraric secment to the sevemth abdominal segment are sinall and obscure: those of the head. first prothoracic, and eighth and nintl ablominal are loneres and more conspienous. The first thoracie secmont has at slining clorsal plate and sometimes a distinct sternal plate. The ventrul lobes of the thror thoracic serments luve inconspieuous fout calli, areh with fine, erect hairs. The first thoravie sorment lass a distinct spiracle: the second and thiml segments are withont spiracles,

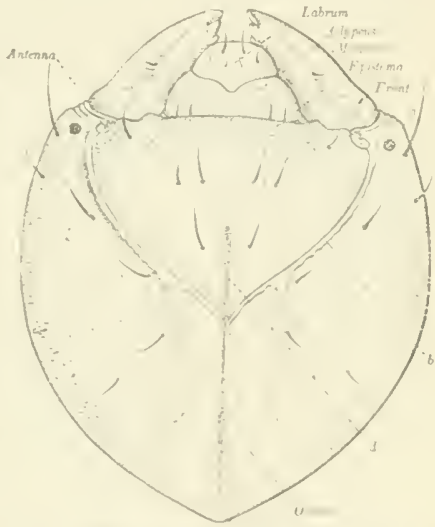

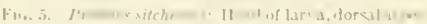

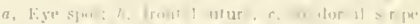

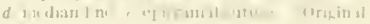

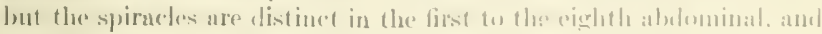

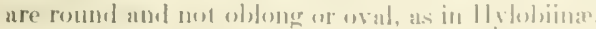

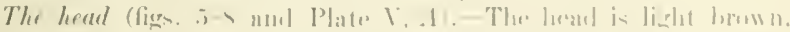

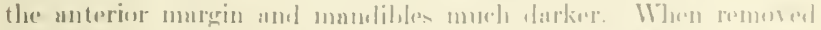

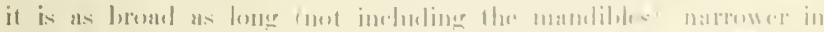

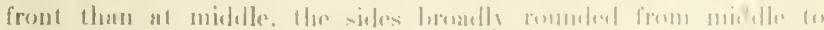

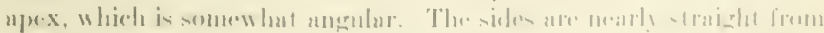

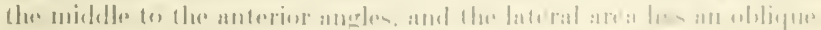

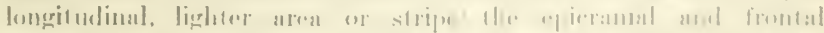

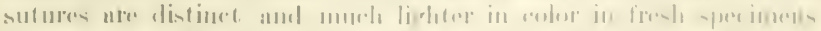

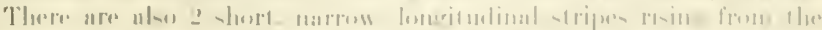


frontal suture. The anatomical details are very similar to those of Dendroctonus. The frontal area is triangular, with a distinet meslian line from the apex to or beyond the middle. The sutural margins are irregular or sinuate. The normal arrangement of the hairs is shown in figures. The anternx are very small, eonical, 1-jointed, and situated at the anterior extremity of the frontal suture. The rpistoma is represented by the thickened anterior margin of the front, with which it is fused. It is ustally darker in color, with the anterior margin declivous and noarly straight, and the lateral angles slightly produced and elerated where they support the dorsal artieulation of the mandibles. The pleurostoma is represented by the thickened deelivous area surtoumling the mandibular foramen.

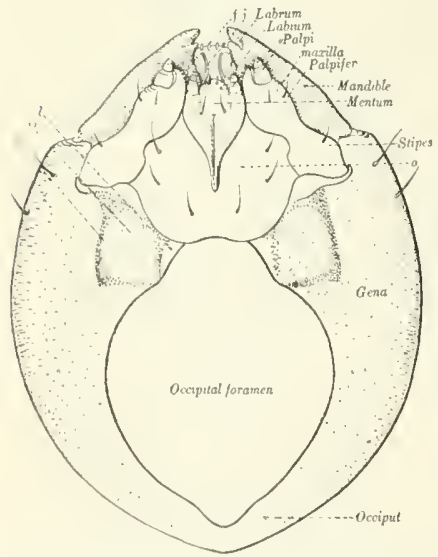

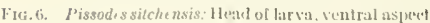
f. I picnl papilta of labrum: i, labial hooks; l. gular plate; $m$, gular area; $x$, location of gular aperteme; a.sulmental folue. isriginal.

The mandibles are rather stout, triangular, with 3 teeth on the anterior half of the inner edge. The ajical tooth is usually acute, the subapical acute and near the apex, and the third or median tooth ohtuse, emarginate, or triangular: ustally the basal or molar tooth is not represented. The articulation is quite similar to that in larix of lindroctonus. The dorsolateral area of the mandible has a small impression and short bristle. The eyes are representerd in some species by mimute lilack spots beneati the exoskeleton, but apparently without lenses. The maxillix (fig. 6) are much longer than broal, with a listinet rardo, and the stipes, palpiger, and inner fobe are fused into one piece: the lateral area is elevated toward the haser, as seren in balsam and when remesed from the head. The palpi ure 2-jointed, and the inner faner of the loles is armed witl stout lacinial teretts. 'The labium (ligr. (i), ventral aspert, has a larere, memloranous submental lobe (o) at auched to and contignous with the integument of the prothoracic sterma and laterally to that of the maxilla; it is also ntlached hy liganents to the intergular plate. The thentum is mepresented los a median triangular chitinoms plate near the midelle of

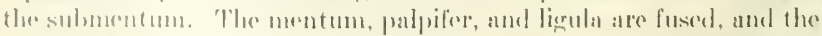
palpi are short, conical, and 2-jointerd: the inner part of the ligula is

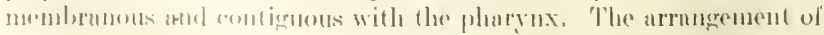


the hairs on both the maxille and labium, as shown in figure 6 , is (haracteristic and quite constant. The clypeus (fig. 5) is broad at base, the sides narrowed to the apical angles, and slightly to distinctly longer than the Jalsrum. The labrum (fig. 5) is more chitinous. about three times as broul as long from apex of clypeus, the rentral posterior margin angular, and extending beyond the marcin of the rlypeus. The labral lowoks are distinet (in balsan mounts). only slightly longer than the labrum, and, as usual, support the anterior portion of the epipharynx. An examination of the larve of 14 species showed that there is considerable specific rarialion in the form and proportion of the frontal area, elypeus, habum, and mandibles. The last have characters of some divisional and sublivisional value, but the characters have not been sufliciently studied to present them in tabular form for the identifieation of the species. Cortain charaeters common to one or more speries of a division are given in a provisional synopsis oll patge 39.

\section{THE PUPA.}

(I)late Y., R.)

An examination of the pupe of 6 species of the first division and 3 species of the second division shows that the following characters are eommon to all: The apex of the postrion tarsus is eren with the apex of the wing pat: the apex of the antema extends towarl the misdlle and in frout of the anterior femmer.

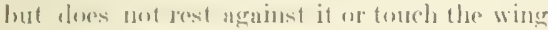

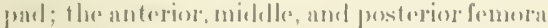

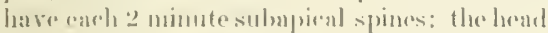
has 2 prominent spines towat the sertex, 2

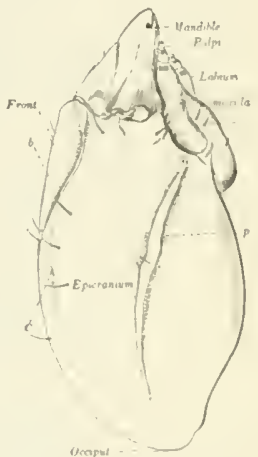

Fini. i. Pissodessitchensis. 11 mad of larva, lateral asin'e.1. b. Frontal suture: $c_{1}$ sululorsil strupe: $\theta$, submental lolu": $p$ ? lateral stripe. (1) riginal.

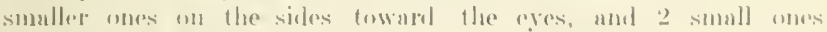

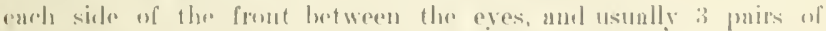
smaller mes on the beak between the frombal ones nut the buse of

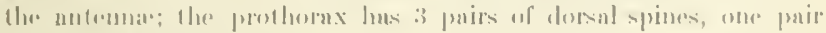
morlerately elosely placent on or tewarel the anterior margin, one widely separated pair wn the melimn arean, and the other pair situ-

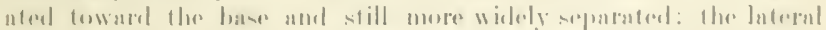

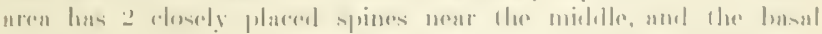

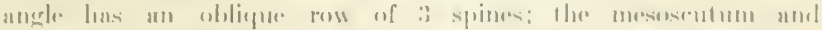

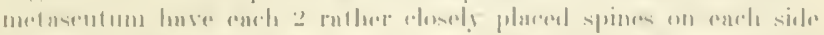

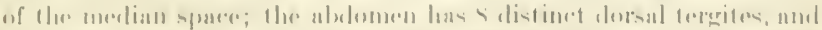

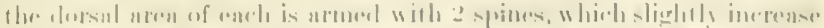

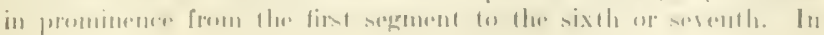


some species there are alternating smaller, less regular spines between the clorsal and lateral ones. The lateral area of each tergite is armed with two spines and the epipleural lobes are each also distinctly or obscurely armed with one or two spines, and the ninth segment, as usual, is armed with two prominent pleural spines. (See Ilopkins, 1909, figs. 37, 35, for matomical nomenclature.)

\section{HOST TREES.}

The host trees of Pissules are, so far as known, restricted to the

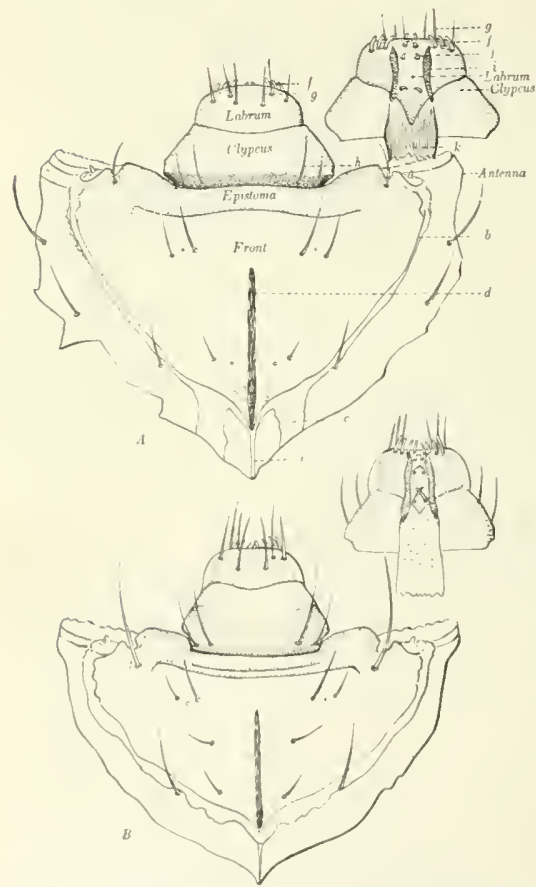

1'1G. A. A Pissed s piperi, front of heal of hrvib b. Frontal suture: c, suldorsil stripe; $d$, median lone; r, eperanfal suture; f, apieal papilla, $y$, latual bristles; $h$, dypeal bristlos; $l$, lubral hooks of epijalnarvageal hracons, j, epipharyngeal maplla; $k$, msoplagus. B3: Piksodes ncmorensis, tront of huad of larva. Nomenchature same as in .1. (corjgina!)

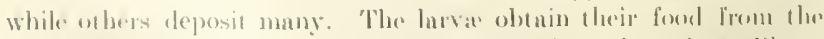

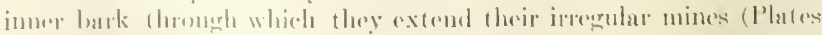
XII 10 XVIII), and when they have completed their development Pinus, Picta, Alies, Larix. Psendotsuga, and Ctdrus. Some of the species infest both living and tying or newly felled trees, while others appear to confine their at ack to those which are sickly, dying, or felled. Some of them infest the liring terminals and upper branches, others the upper or midille, stem, or base; some prefer to inlest the thick bark of large trees, while others show a preference for the thinner bark of saplings and poless. (See table, pp. $41-4 \cdot$.)

\section{GENERAL HABITS.}

The expers are depositel in arities exavated br means of the beak in the outer or inner portion of the inmer bark. Somes spe(ies deposit one or two exges in a singere cavity, conifers, and include 
they excavate transformation colls, or pupal anses, in the outer portion of the wool, or, rarely, in the imer bark. These ecells are inclosed by a thick covering of exrekior-like wourl fibes. forming the so-called "chip cocoons," which are perhaps a more characteristic feature of the species of this genus than of any other.

\section{GENERAL LIFE HISTORY.}

The characteristic features in the life history of the species are the long life of the adult, the slow sexwal matmity, the long period in which eggs may be deprosited by a single ferrale, and a single generation annually. In some species the boods develop within two or three months after the egges are depesiterl, while in others it requires a longrer period. The adults of some of the speries emerge from the bark and hibernate in the ground, while others pass the winter in the bark.

\section{GENERAL DISTRIBUTION.}

The genus is representerl in all sertions of the l'nited states characterized by natural growth of their lost trees, and in olher sections where sweh trees have been introdued to a suffieient extent tosupport them. (Sie table, pre. 40-41.)

\section{THE NORTH AMERICAN SPECIES OF PISSODES.}

\section{NATURAL CLASSIFICATION OF THE SPECIES.}

In the following key and sronepses (pp. 30-35) an uttempt is made towarl a natural classifieation of the speres of Pissodes into primary

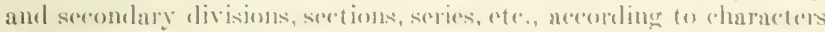
whela indirate lines of spectalization and natural aflinities. It will he

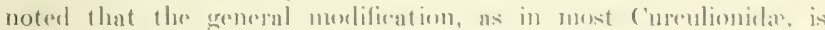
from a short or stout berak to a lengere or more slemeler one, ant in gencrul from sumall to latger forms

The rhaneters of the pronotum, as commonly used to indiente

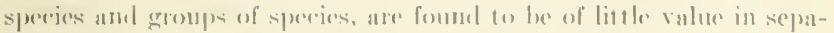

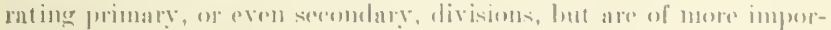

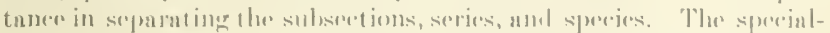
izalion is planty from a roumeled, obtuse, fo a rerelangulas mal

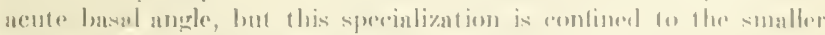

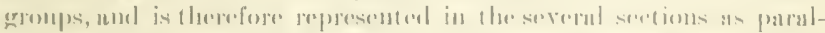

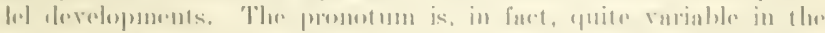

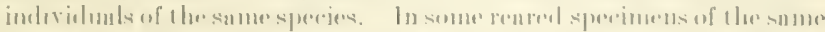

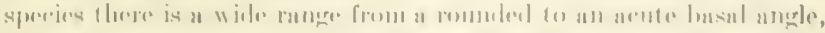

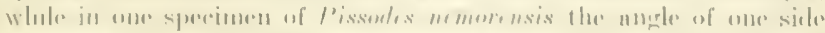

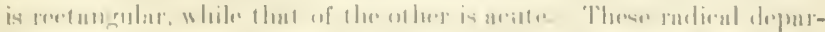

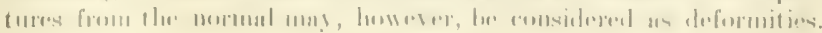


The lengeth of the beak also varies; thus, in some of the females it is shorter than in some males of the same species. The elytra are more or less variahle in form, but appear to be more constant than the of her parts, and show litth or no sexual difference.

The character and position of the spots of densely placed scales appear to be of special value in the classification of the gemus, but these are sometimes rendered obscure in old, rubbed, and thirty speeimens. The scales are so firmly attached, however, that they are often sufficiently retained in old specimens to be of value. Dirty specinens can be easily cleaned with chloroform or xylol, the latter being especially valuable for the removal of resin.

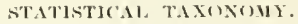

In a comparative study of the dhalacters which distinguish the major and ninor divisions and species of a gemus or a larger group of

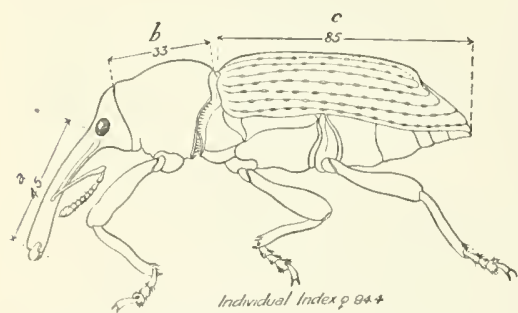

liff. 9.-Pissodes fraseri: Lateral aspect, showing methou of deleruining individual index. $a$, length of beak; $b$, length of prothorax; $c$, length of elytra. (Original.) organisnrs, a progressive modification of certain parts of the borly structure is usually found to serve (together with other characters) as an inclex to a natural classification. Therefore the importance of luving some clear and definite method of indieating the range and limit of such lines of modification or specialization is apparent.

'The writer's experience with the statistical nethorl in comparative studies of such morlifications has convinced him that whom it is acouratoly applied a mathematical formula may be detromined to express the linit and relative taxomomic importance of a given modification in one or more structural characters, to inclicate specific dillerences, and to show the relative position ame rank the sjores oceupy in a natural rhassification. Thus wo may achot for certain (romps of insects a statistival taxomomy as a muike towarel the classilication ol' the spereses into natural divisions.

la the lank-wervils of the erems / issodes wo havo a good example for the application of this methoel. (One of the principal limes of modiliontion avaibuble for statistical sturly is the progrossion olongation w the beak. Therefore when we compare the arerage rate or mode of the lomglh of tle beak to both the lenegth of the prothorax sond lengeth of the olven (lig. 9) in a number of individunls of one

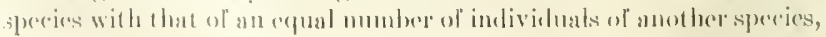


wo matter what diflerences there may be in the length of the boty of the imliviluals, we get a mathematical expression, or index, of the difference in their relative proportions.

The following examples will serve to illustuate the applieation of the methoil: ${ }^{a}$

\section{Example 1.}

Female indivirlual of Pissodes strobi.

$a$, Length of beak, 29 micrometer divisions.

$b$, Length of prothorax, 31 miscrometer divisions.

c, Length of elytra, 73 micrometer divisions.

$a \div b=.935$.

$a \div-c=.397,+.935=1.332, \div 2=.666=$ Index of relative propertions of an individual.

Iow, if 50 male indiviluals of this species show a range in the individual index of 61 to 64 , with an average or mode of 63 , and 50 femalus show a range of 65 to 69 , with a mode of $6 x$, the relative proportions for earh sox and in the species are expresserl by the formulat, of $63-q$ fis.

\section{Example :.}

Female indivilual of Pissodes fruseri (fig. 9).

a, Length of beak, t5 micrometer clivisious.

$b$, Length of prothorax, 33 mir.rometer divisions.

c, Length of ilytra, 85 micrometer divisions.

$a \div b=1.366$.

$a \div c=.529+1.366=1.895, \div 2=.917+$. If 50 malo individuals show an inchex range of 72 10 73 and a modo of 72 , and 50 fomales show a range of 91 to 111 , with a mole of . Ion, the formula weruld bre $872-8100$.

f. strobi, formula of tis

I. fraseri, formula $372-8$ ( 1 (H).

Areording to other tharacters, these two speciss fall in the same division of the gende, but in clifferent sulclivisions. The formulas for the species of the first tivision range from $\delta 57-q(2)$ to $\delta 72-\$ 100$. Those of the lirst suldivision range from

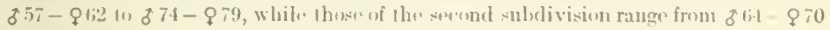
(4) $87: 2-Q 100$.

'Thus the formulas for $l$ '. strobi und $l$ '. fraseri, logether with the

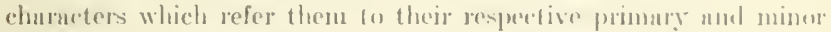
divisions, imlionte the natural position and rank they shoulel oneupy in tla rasiliention. (Sire l'lute II.)

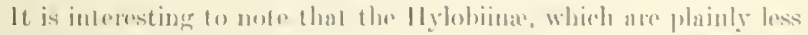

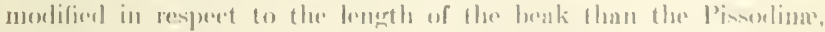

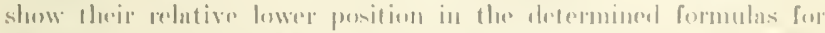

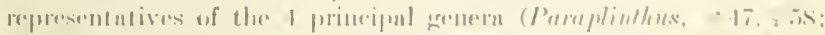

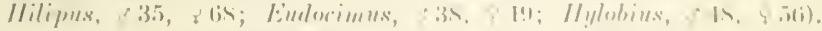

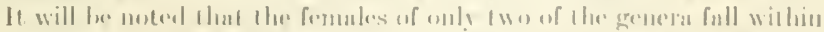

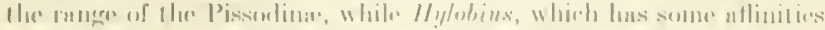

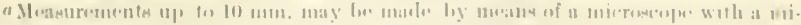

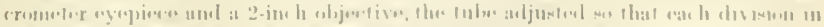

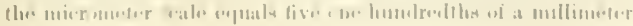


with I'. atfinis of the second division of the genus l'issodes, does not come within the range, hut oecupies the position probably held by the more primitive forms of the affinis division. (See Plate II.)

\section{MORPIIOLOGICAL AX1) JHYSIOLGGICAL, CHARACTERS AND CHARAC-} TERISTICS.

The plan of embining morphological dharacters and physiological characteristic's as a basis for specific distinction, as diseussed by the writer in the technical contribution on Dendroctonus (Ilopkins, 1909, p. 64), has been followed in the study and classification of the species of Pissodss. The close resemblance of the adults of allied species and the wide range of speeific variation render it very difficult and often practically impossible to refer some of the individuals to the species by externat characters of the alults alone, but with information on the distribution, host, habit, seasonal history, etc., they can often be referred to their species without a moment's hesitation. Specimens withont locality labels and some adelitional information are therefore of no value to the economic investigator, and will cviclently become of less and less ralue to the systematists. The importance of utilizing bionomic data as guides to the identification of species will doubtless become nore popular in the future and contribute to a more rapid adrancement of the essential knowledge required by the systematic and economic entomologist in research work.

\section{KEY TO THE SPECIES.}

1. Elytrat interspaces 3 and 5 broader or more clevated than 2 and 4.

A. Elytra alway with anterior and posterior spots.

11. Elytra with distinct spots near vertex of declivity.

1i. Buak moderately stout, always shorter than prothorax.

e1. Elytra with distinct anterior spets and very large posterior ones.

f'osterior spot with distinct dark berder............ 1. simitis

I'ostering spet without distin.t dark bender....... 2. utahensis.

c2. Elytra with indistinct anterior spots and small posterior ones.

3. barberi.

b.. lieak alonder, whorter or longer than prothorax.

c3. Elytra with anterior and posterion epota large.

Piosterier spots of elytrat without slark border. Pacific Coast.

4. sitchensis.

l'():terior ppots of elytra usually with dark border. Rocky

Mlountains.......................... 5. engetmunni.

Jensterior spots of elytra with or without dark borter. Eastern

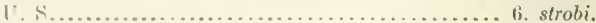

\&. Elytra with emall to molerately large anterior and posterior spots.

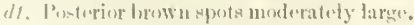

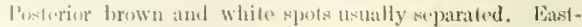
arn and northorn l'. ............. 7. approximatus.

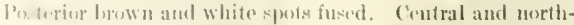

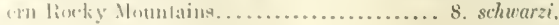




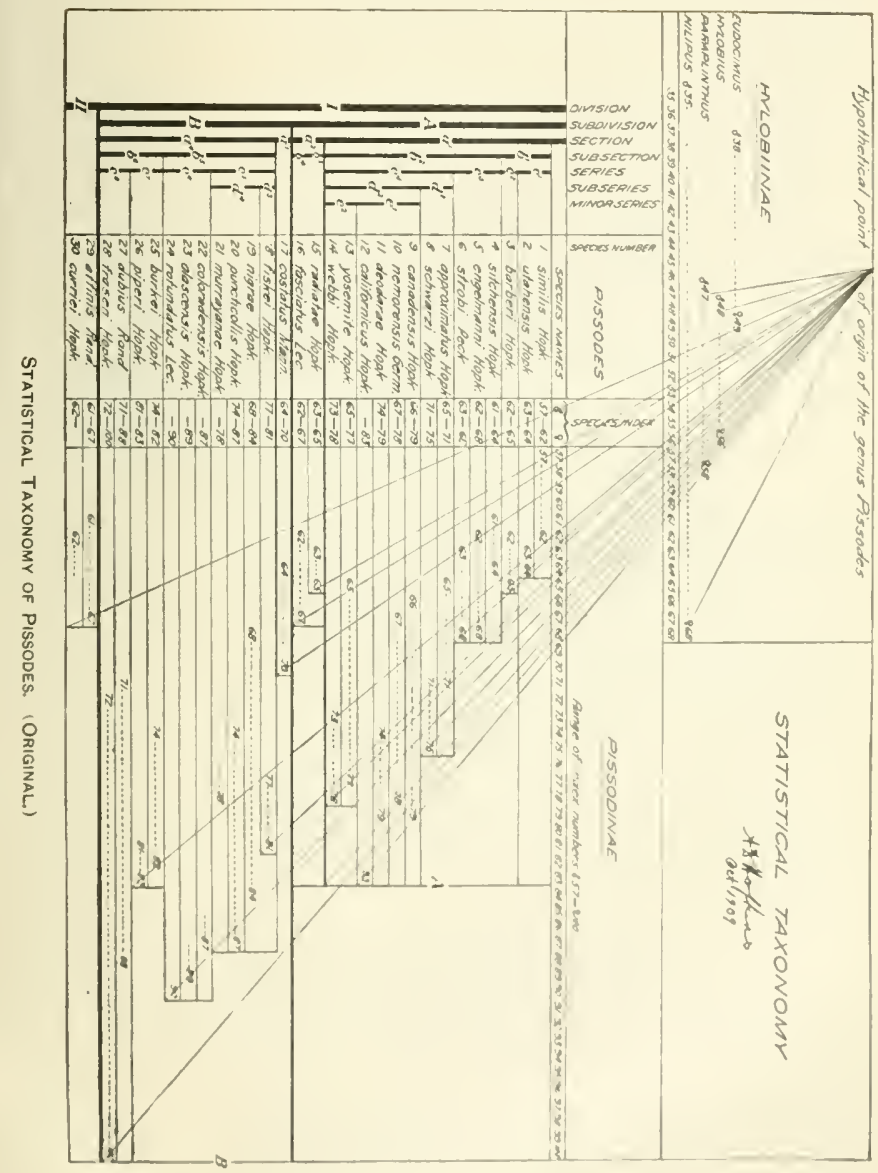



d2. Postcrior brown spots small.

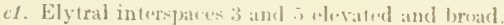

Posterior spots fused, the yellow ene larerer. Manitolya....................... 9. canadensis.

Posterior spots usually separated, yellow one small.

Elytra noticeably narrowed posteriorly from base.

10. nemorensis.

Elytra not woticably narrowed pesteriorly irom bast. Sunth Atlantir states..... 11, dendarit.

Elytra noticeably narrowed posteriorly; whitw and lowwn spots separated, the latter very small.

12. culifiormirus.

e2. Elytral intersyaces 3 atnd 5 narrow, strongly thevated.

I'romotal punctures coarse but not dense.. 13. yosemite.

Pronestal punctures coarse and dense...... 14. weblit.

a2. Elytra with transwerse band of white and jollow wallw near vertex

63. Pronotum with justerior angles atute........... 15. radiatiz.

64. Pronutum with posturior angles subrectangular...... lti. fasciatus.

B. Elytra usually without distinct anterior spots, and with prasterior spot anterior to vertex of declivity.

a.3. Pronotum with basal angles sulbrectangular.............. 17, rostatus.

a4. Pronotum with basal angles rounded.

6.5. P'ronotal punctures disinelly soparated.

c.5. Promolum now distinetly narreser than wytra.

d.3. Promotum stout, denply consirieted anteriurly. 18. fiskei.

d4. I'romelum sulwelungate, not derply constrieted anteriorly.

Pronotum moderately sout; elytral interspaces 3 and 5 scarcely wesated: with anteriur spot . . . . . 19. nigr.r. Pronolum r.longale.

Elytral interspaces 3 and 5 slighly elevated, thattened; with anterior spot . ............. 20. puncticollis.

Elytral interepaces 3 broader and more clevated: withant anterier sput - . . .......... 21 murrmymat.

ef. P'ronotam di-tinelly natrower than olytra.

Promotal punctures irregular, not denos: punctures of sorize irregulat.. . . . . . . . . 2.2. colerate nsis.

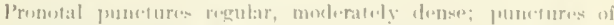

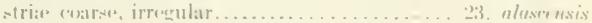

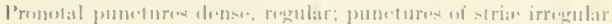

21 motumdatus

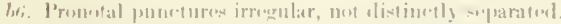

$\therefore$ Elytral strat with punclures vers irrezular.

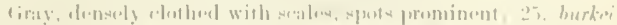

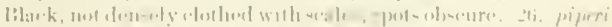

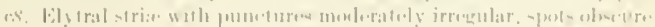

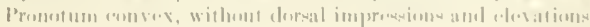

27 aluburs

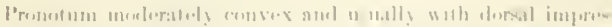
sions and elovationt .. .

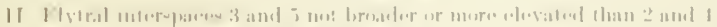

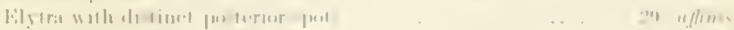

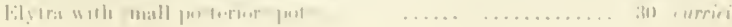




\section{SYNOPSIS OF ADULT CHARACTERS, WITH DESCRIPTIONS OF NEW SPECIES, ?}

Elytral interspares 3 and 5 broader or more elevated than 2 and 4.

Division I, pages 32,43 . Elytral interypaces 3 and 5 not broader or more elevated than 2 and 4 .

\section{DIVISION I.}

Division II, pages 36,64 .

Elytra always with distinct spots of densely placed seales on the anterior lateral area and always with spots or bands of scales situated near the vertex of the declivity.

Subdivision $A$, jages 32,44 .

Elytra usually without distinct spots on the anterior lateral area and with small spots situated between the vertex of the declivity and middle of elytra.

Subdivision 13, pages 35,56 .

\section{SUBnTVISION A}

Elytra with distinct spots near vertex of declivity........ Section a I, pages $32,44$. Elytra with transverse band of white and yellow scales near vertex of declivity.

\section{Section a1.}

Section a2, pages 34,55 .

l3ak moderately stout, shorter than prothorax; pronotum with basal angles suboltuse; clytra with interspaces 3 and 5 strongly elevated and rugose.

Subsection 111 , pages $32,44$.

Beak sender, shorter or longer than prothorax; pronotum with basal angles rectangular; atyral interspaces 3 and 5 moderately to strongly rlevated.

\section{Subsection bI.}

Subsection b2, pages 33,46 .

Elytra with distinet anterior spots and very large posterior ones; pronotum distinetly narrower than elytra, functures indistinet, irregular ......... Series cl, page 32.

Elytra with indistinet anterior spots and suall transverse josterior ones; pronotum not distinctly narrower than elytra, punfures distinct and regular.

Series 2 , page 32.

\section{Sories el}

Length 3.7 to $4 \mathrm{~mm}$; hrown; pronotal and elytral punctures moderately coarse; prosterior spot of elytra with distinet lark border. Naine and high mountains of North (arolina, probably in Abirs fraseri, and New llampshire in Abies balsamea.

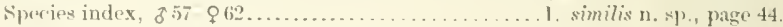

Length $3.9 \mathrm{~mm}$; dark browa; prometal and efytral punctures coarse; posterior spot of alytra withont distinct dark border, third and fitth interspaces with acute rugosities, spots prominent. J'ark City, Ltah, and loar lake, liritish coltumbia.

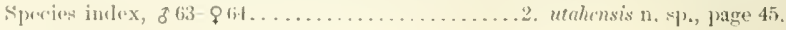

\section{Sories e?.}

Langth is to $5.5 \mathrm{~mm}$; hlack; pronotal and elytral punetures very coarse; elytra witl interepaces 3 and 5 broad and prominent. Ilumblelt, Cal., Astoria, Oregon,

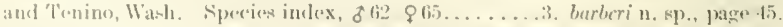

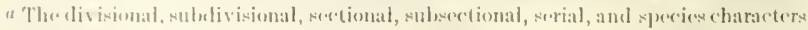

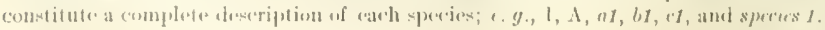


Subscction bs.

Elytra with large anterior ant josterior spots; sides parallel; leak never longer than

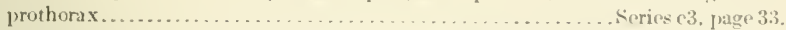

Elytra with *mall to moderately large anterior and posterior spots; wides usually slightly narrowed posteriorly; beak sometimes longer than prothorax.

Series c.3.

Serics c.4, patge 33 .

Length 4.2 to $5 \mathrm{~mm}$; brown; pronotum distinctly narrower than elytra, not distinetly shining, and the punctures moderately coarso' and dense; posterior spots of ulytrit without dark border; punctures of strie coarse, distinet. lloquiam and Pialschic, Wasb., in tops of Pirea sitchensis. Apecies index, of $61-964$.

1. sithensis 11.51 ., page 47.

Length 5 to $5.3 \mathrm{~mm}$; brown; pronotum not distinctly narrower than clytra, shining, and the punctures coarse; posterior spots of elytra usually with faint lark londer; punctures of strie indistinct, expecially on lateral area. Smith's Ferry, Ilaho, and Pikes Peak, rolo., in tops of Pien engrlmanni. Species index,

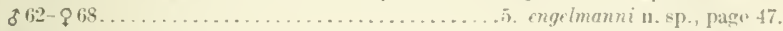

Length 4.5 to $6 \mathrm{~mm}$; l, rown; pronotum slightly narower than elytra. moderately shining, and the punctures demse; posterior spot of clytra witle without faint dark border. Eastern Inited States, in terminals of l'imus strobus, rarely in terminals of Pinus resinosa and terminals of Picea. Spercies index. 3 ti3- 80 s.

6. stroti Perk, page 4.s.

Series r.;. -

Ponterior brown spots of elytra moderately large; fork of mate genitalia wery stout.

Subseries di, page 33 .

Posterior brown rpots of elytra small; fork of male genitaliat long and slondler.

Subseries d2, paint 33 .

Subscries dt.

Length 4.3 10 $6.7 \mathrm{~mm}$; brown; pronotum not diwtinetly natrower than wytra, punc-

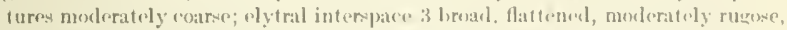
and posterior white and yollow spests ustally reparifed, the brown one smaller lut not very small as in species in, and the white one extending over the serond interpare. Monntains of Norll C'arolina morlhwarl to Vow llampehire, and wert to l.ake superior region, in J'inns under bark on stumpes and loges and trunks of dying trees, and loase of eaplings. Sperios index, of tii 871 .

7. approrimatus n. -19., page 19.

Length 5.2 to 6.7 mm.: brown; pronotum slightly nurrower than ilytrit, prunetures

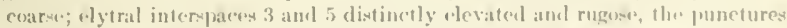

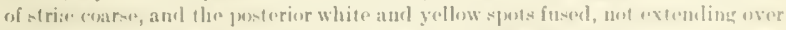

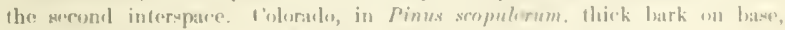

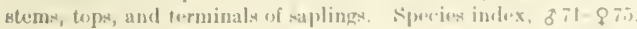

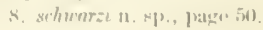

Siubseries d?.

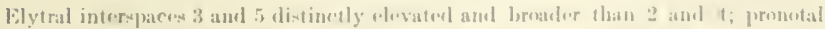

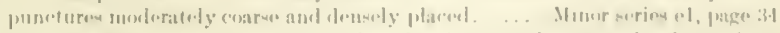

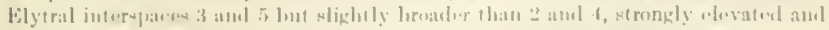

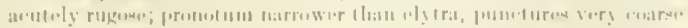

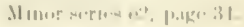


Minor scriese1.

Length 6.2 to $7 \mathrm{~mm}$; brown; pronotun as broad as clytra, with sides rounded; elytra with sides searcely narrowed posteriorly, interspaces 3 and 5 broad, elevated, rugose, the postrior spots fused, and the yellow one large: beak not longer than the prothorax in the males. Winnipeg, Manitoba, in Pinus? Species

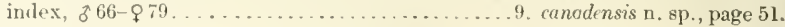

Length 4.9 to $7.7 \mathrm{~mm}$; brown; pronotum whih sides not strongly rounded; elytra with sides narrowed posteriorly from bast, posterior spots usually separated, the yellow one very small and the white one extending to first interspace; beak usually longer than prothorax in both sexes. Boardman, N. C., and mountains of North Carolina, to Florida and Texas, in bark of Pinus logs, stumps, trunks of dying trees, and rarely in base of sallings. Species index, $\delta 67-q 78$.

10. nemorensis Germar, page 51 .

Length 4.2 to $5.8 \mathrm{~mm}$; light brown; body slender; pronotum slightly narrower than elytra; elytra with sides nearly parallel, interspaces 3 and 5 but slightly elevated, posterior brown spot very small; beak longer than prothorax in both sexes. Experiment, Ga., in stems, branches, and tops of Cedrus deodarx. Species index,

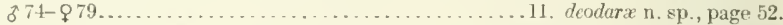

Length $8.6 \mathrm{~mm}$; brown; pronotum broad, with sides broally ronnded; elytra with silles distinctly narrowed posteriorly, interspare 3 very hroad, not eoarsely rugos, as in yosemit; posterior spots separated, the brown one very small; beak distinetly longer than prothorax. Yosemite Valley, Cal., in bark of living pine with $P$. yosemite. Species index, $९ \$ 3 \ldots . . . . .12$. ealifornicus n. sp., page 53.

\section{Hinor series $\epsilon^{\prime}$.}

Lingth 5.1 to 7.7 mm,; brown; pronotal punctures very coarse, not dense; elyira with sides nearly parallel, interspaces 3 and 5 strongly el:vated, acntely rugose, punctures of stria rather coarse, and posterior spots fused on lateral area. Yosemite Yalley, Siskiyou County, and Kak Tahoe, Cal., in P'inus ponderosa and P'inus lambertiana. Species index, o $65-q 77 \ldots \ldots . . . .13$. yosemite $\mathrm{n}$. sp., page 53 .

Length to 5 to $6.8 \mathrm{~mm}$; brown; pronotal punctures very coarse and dense; elytra with sides nearly paralle], interspares 3 and 5 elevated and rugose, punctures of striæe rather coarse, ansl ponterior spots prominent and fused on the sides. Mountains of sonthern New Mexion and Arizona, in l'inus strobifarmis and l'inus

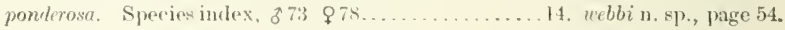

\section{Siretion as.}

Pronotum wilh post:rior angles arcutu.

Pronotum with posterior anglpos subrectangular..
Subsection b3, page's 3.t, 55 . Subsection b4, pages 34,55 .

\section{siubsetion b.i.}

Length 5.1 to 7.1 mm.; loww; pronotum Iroakcr toward lanse, angles acute, sides

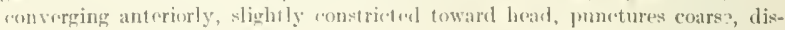
tinct ; rytra with anteriur spots small, yollow, and lis posterior band principally of whitrencales. Monterey, fal., in batrk of legs and trunks of l'inus radiata:

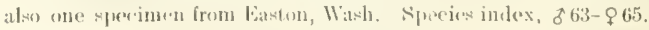

\section{siubstion l. .}

15. rudiati' 11,8$]$ '., plage 55.

Length $5.1108 .3 \mathrm{~mm}$; brown; promatum natrower than thatra, sides rounded and

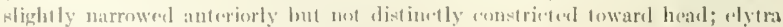

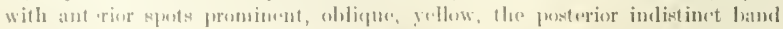

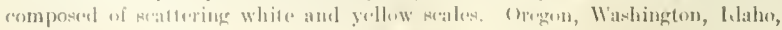

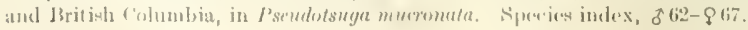

16. fasciatus Lo c'ontr", jage 56. 


\section{Subdriston B}

Pronotum with basal angles subrectangular; beak rather stoul, molerately long.

Sertion a:3, jages $3.5,57$.

Pronotum with basal angles rounded; beak slender, moderately to very long.

Section at, jages 35,58

\section{Section as.}

Length 5.5 to $7.1 \mathrm{~mm}$; dark brown; pronotal punctures not distinctly separated; elytra with faint anterior spot toward the middle atul indistinct spots of recldish brown and white scales behind the middle, interspaces with many minute white epots toward sides and on declivity. Hoquiam, Wash., in thick has on trunks of dying trees and stumps of Picea sitchensis. Species index, $\delta$ fit $Q 70$.

17. rostatus Mannerheim, jage 57 .

\section{Section $a \cdot$.}

Prototal puncturis distinctly separated; punctures of elytral strix snall to roare.

Subsertion 1,5, pages 35,59 .

Pronotal punctures irregular, not distinct]y separatel; junctures of elytral stria* wory

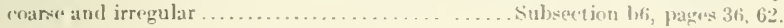

\section{Subsertion b.5.}

Proustum not distinctly narrower than elyta.

..... viries ( 5 , page 35 .

Pronotum distinetly narrower than elytra... Nories $(\cdot 6$, page 36 .

\section{Serifs e.5.}

l'ronotum short, stout, sides strongly rounded and constrinted foward the anterior margin; elytral interepares strongly elevaterl with rather cuarse rugosities.

Suls:ariug (1:3, wase 35 .

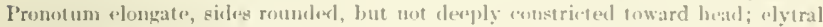

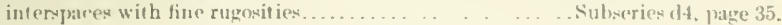

Sulsorips d.i.

Length 4.2 to $5.2 \mathrm{~mm}$; dark brown; clytra without anterinr spet lout wilh hroad postr.rior one, interpaces 3 and 5 strongly elasalcel, convex, rugose; punctures

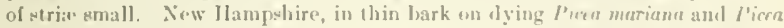

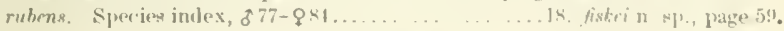

\section{Subseries di}

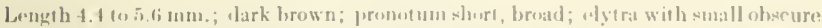
auterior sjuts and distinct posterior ones miluated toward the middle, interspaces

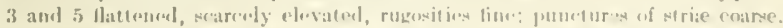

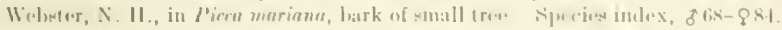

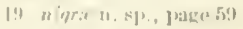

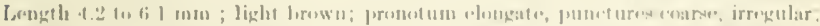

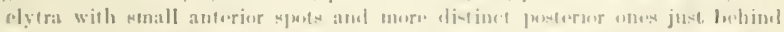

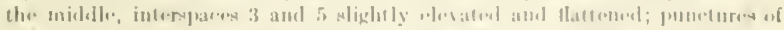

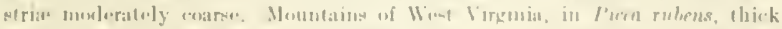

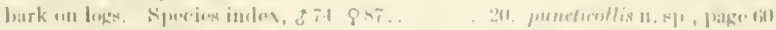

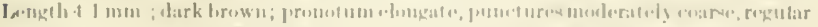

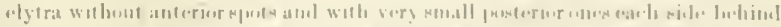

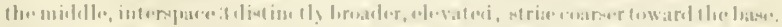

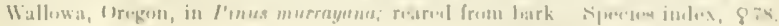


Series $c 6$.

Length 6.9 to $7 \mathrm{~mm}$; dark brown; jronotal punctures irregular, elytra without distiuct anterior spots; but with distinct spots of yellow scales behind the middle, interspaces 3 and 5 strongly elevated, and punctures of strice irregular. Leadville, Colo, Natioual Park, Wyo., and Plack IIlls, S. Dak., in Picea canadensis thick bark on base of trees. Speries index, $\$ 87$.

22. coloradensis n. sp., page 60.

Length $6.5 \mathrm{~mm}$.; black; protonal punctures coarse, regular, elosely placed and rather deep; elytra without anterior spots, but with small, rather distinet, posterior ones, punctures of striæ coarse, irregular, and smaller on the lateral area, interepaces 3 and 5 redclish, strongly rlevated, and broad. Aretie Circle, Alaska, and Montana in Picea engelmanni. Speriex index, Q.s9.

23. alase $n$ sis $\mathrm{n}$. sp., page 61 .

Length 6 to $7.3 \mathrm{~mm}$; black; promotal punctures dense, regular; elytra rarely with small anterior white spots, but with small white spots behind the middle, interspace 3 very lroal, interspacial rugosities not coarse, pronetures of striæ irregular and not smaller on the lateral area. Marquette, Mich., Lake Superior region, probably in Picu. Speries index, $\$ 90 . . .2 .24$. rotundatus Le Conte, page 61.

\section{Subsection 16 .}

Punctures of elytral striæ very irregular, spots of scales moderately distinct; pronotum not distinetly narrower than elytra.................

Punctures of elytral strix moderutely irregular, spots of scales evident but small and obscured by seattering white or ycllow seales; pronotum distinctly narrower

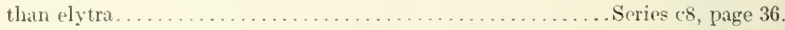

\section{Series e}

Length if to $7.7 \mathrm{~mm}$.; gray; elytra and pronotum rather densely elothed with whitish seales; clytrat with rather distinct anterior and posterior spots, and punctures of strie not very closely placed. Ouriy, Colo., Alta and Park City, Ltah, prolably in flbies? Species index, $874-\$ \$ 2 \ldots \ldots \ldots \ldots \ldots .25$. burki in. sp., page 62 .

Length 7.4 to $10 \mathrm{~mm}$; black; elytra and pronotum sparsely clothed with whitish scales; wytra with anterior and posterior spots evident but small, and punetures of strixe very deep and closely placed. Mount Rainier, Wash., and Centor-

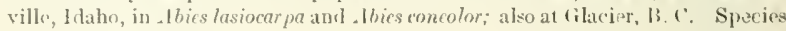

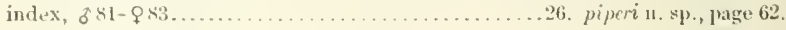

Serles is

length 4.8 to $5.7 \mathrm{~mm}$; black; lask moskrataly long; pronotum convex, without Iorsal irregularities. Mame to lake Supreror, in Abirs balsamea. Speeies index, $872-\$ 88 \ldots \ldots \ldots \ldots \ldots \ldots \ldots \ldots \ldots \ldots \ldots \ldots \ldots$. dubins La Conte, page 63.

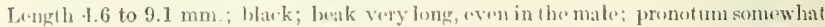
flattened, and dsually with dorsal inegularities, sametimes distinctly impressed fowards lase. High mountains of North farolina in .lbes fraseri. Species index, $872-q 100 \ldots \ldots \ldots$. ...2. fraseri n. sp.. puge 63.

\section{I)}

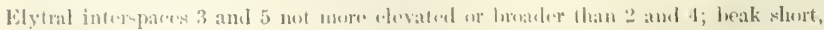

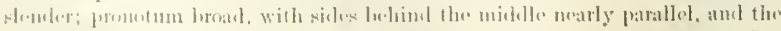
latal angles metamgular; pumetures of elytral striar menlerately abirse, regutar; posterior tilitia of male fringenl with loug loristles. 
Lenglh 5.5 to 8 mm.; black, wytrit with or without fant antorior spots lout with distinct transverse spots of white or vellow soles near vertex. and the punctures of strie moderately coarse. Wisconsin to lew llampshire. in l'inus strobus.

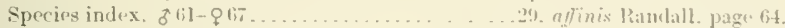

Length 5.6 to $7.7 \mathrm{~mm}$; black, wytra with ohseure anteriur spots and small posterior

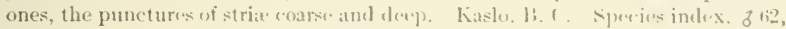
30. curiti 11 . - 11.. page ti5.

\section{SYNOPSIS OF PRIMARY SEXUAL CHARACTERS.}

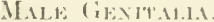

Stem with apex uniformly rounded....

H)ISI I I

Siction a1.

Fork slonder sieries 1.5 .6

Fork slort . .

sprexitis 4

speries 5

Fork long.

सperies 6

l'ork moderately stomt

Fork lung and stutit. .

Fork long and slrender.

Nitian ar.

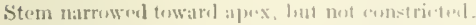

Fork long anul slemler. .

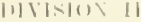

Fork very stent

Ajuries 293,20

\section{SYNOPSIS OF SECONDARY SEXUAL CHARACTERS}

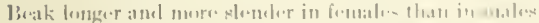

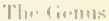

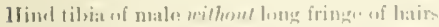

1 1) isin, 1

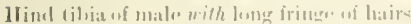

l)isisin II

\section{$1181 \times 10 \times 1$}

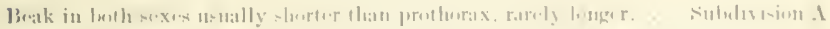

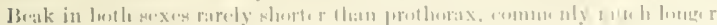

sillulivisinn l?

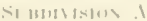

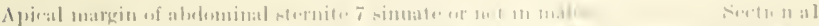

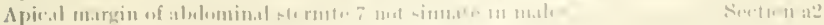

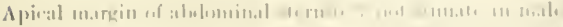




\section{subsection b2.}

Beak shorter than prothorax in malse, rarely longer in females.

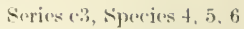

lieak as Jong as prothorax or longer in males, usually longer and often distinctly so, in femajes...................... species $7,8,9,10,11,12,13,14$

\section{Sicrion a'.}

Beak in both sexes shorter tham prothorax ................... Speries 15,16

\section{STBMTISION 1 .}

Apical margin of abdominal sternits 7 fantly sinuate, but without apical process in

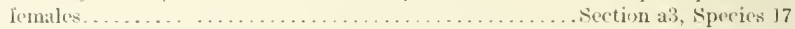
Apical margin of aldominal sternite 7 without 'or with process in males... Section a4

Srrtion af. subsection b5.

Apical margin of abdeminal sternite $\rightarrow$ sinuate, but without median process in

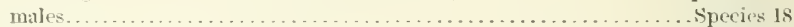
Apical margin with median process in males.................... species 20 Subserion bri.

Apical margin of aldominal sternite 7 with apex uniformly rounded in males.

\section{I)ISIOA II}

Species $25,26,27,25$

Beak shorter than prothorax in hoth sexes, apical margin of ahdominal sternite 7 with truneate process rising from dere], emargination in males......... Species 29,30

\section{SYNOPSIS OF PUPAL CHARACTERS.}

\section{JVISION I.}

Jlead with one or more minute spines on posterior margin of eyes. . . Subdivision A Head without minute spines on posterior matrin of eyes.......... Suludivision If

\section{N⿴囗十मVISH 1}

Abdominal tergites with small spines alternating with larger unes, especially on

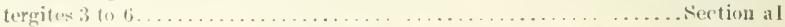
Abdominal tergites without small spines alterniting with larger tnes..... Sertion a2

\section{Sution at, Sieries cs.}

Aldominal tergites 5 and fi with small spines between the more prominent dorsal

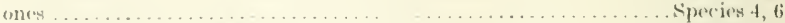

Aldominal tergites 5 and ti without small spines betwern the more prominent dorsal unes siperies 5

\section{siresies.}

Ablominal torrites 5 to 6 without small spincs between the more proninent dorsal 1) $114 \cdot 4$. species:-14

\section{Section 1":}

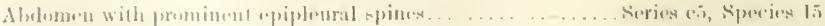

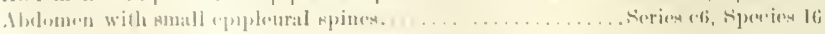




\section{Siburision $\mathrm{B}$}

Aldominal tergites with small spines alternating with the larger ones and with small spines befween the mure prominent dorsal unes.

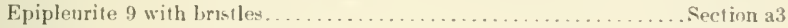

Epipleurite 9 without bristles....................... Section at

Section a.3.

Abdominal tergites 4 to 5 with two small spines between the moro prominent deral

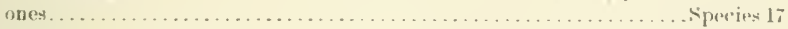

rection at.

Abdominal tergites 4 to 5 with four small spines lutwewn the umore prominent dorsal ines.

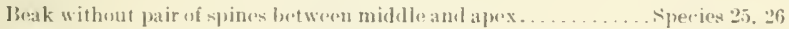

Beak with pair of small spines between mildle and apex......... viperies 27

IHIISION 11

Alodominal tergites 4 and is with two small spines lestwern the more prominemt dorsal ones; beak with pair of small spines betweren alpex and middle........ species ? $2 y$

\section{SYNOPSIS OF LARVAL CHARACTERS.}

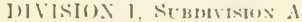

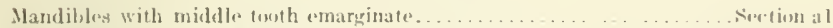
Mandihles with middle tesols triangular.

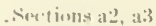

Mandibles with midlle tooth emarginate or triangular. . . . . . . . . . . . section at

Siction a1

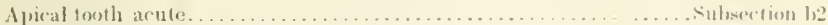
Ablominal mpiracles distinet.

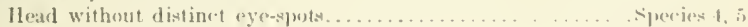

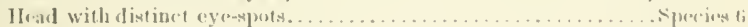

Aluminal npirales distimet.

Sirics ch.

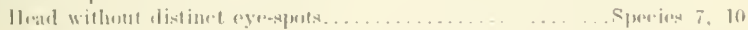

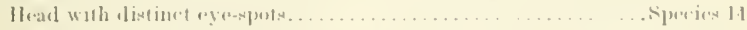

Sirtion 1 .

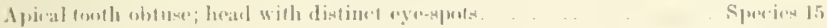

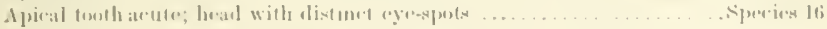

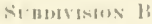

Sirtion n;

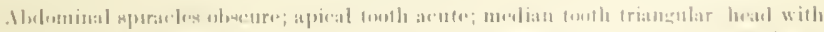
dimfinct ayonplute.

\section{Sicfion $n$ t \\ Siries ris}

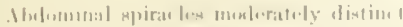

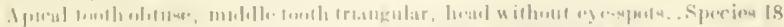

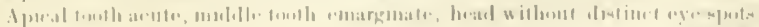




\section{Sirits $c^{2}$}

Abdominal spiracles molerately distinct; apical, subapiral, and median teeth obtuse; head with distinct eye-spots. . . . . . . . . . . . . . . . . . . species 25

Ahdominal spiracles obscure; apical tooth acute; middle towth triangular; head without distinct eye-spots............................. speries 26

Sitries cis.

Ahdominal spiracles obscure; apieal tonth acute; median tooth emarginate.

Species 27

Apieal tooth obtuse; median tooth imarginate.

Sipecies 28

\section{TABLE OF DISTRIBUTION.}

\section{THE ITORLD}

In Europe and Asia, from Spain and England into eastern Silyeria and Japan and northward into Sweden and Russia. probably to the Iretic Circle; in Torth . Imorica. from Dlexieo and Florida to the Irotic circle in Ilaska and eastward to the Itlan-

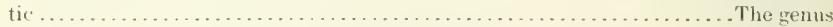

\section{NORTH AHERII HISISION 1.}

SiBuvisux 1 .

Sirtion $n 1$.

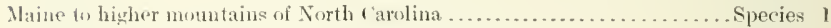

Anumains of $[$ tah to hear lake, Iritish Columbia................. species 2 (')ast of northwestern ('ahifornia to western Washington .............. species 3 Toast of northwestern Oregon and western Washingtum............... speries 1 Smitls Ferry, Idaho, to Pikes Peak, Colorado ........................ species 5 New Brumswick, sonthwest through mountains to Biltmore, X. I. (dis-

tribution of white pine) .................................... 6

bastern United states. south through mountains of North farolinat and

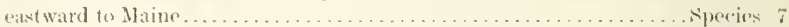

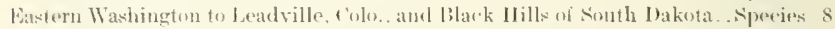

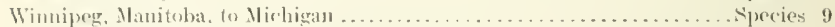
Atlantic eoat region and lower Instral life gome, northward probably lo

Long loland. New York, and westward through the linlf Staths inte

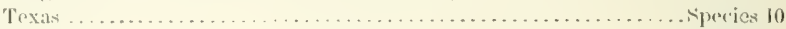

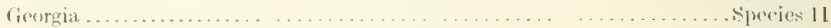

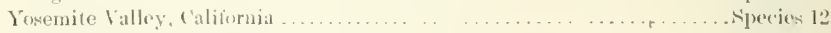

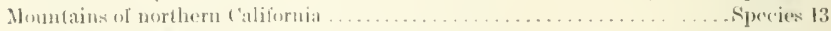

Somberm New Mexion and Irizona, and probably mountains of wextern

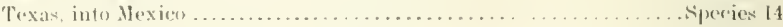

Sirction $a !$

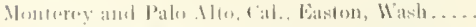

Spercise lis

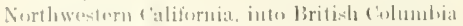

sperese 16

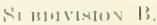

Sictiont ori.

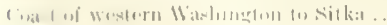


Scition a $i$.

Sew llampstire

Species 15

New Hampshire

- iperies 19

High mountains of llest Virginiat

speries 20

Northeastern Oreg(r)

- vperies 21

Black Hills. Gouth Dakota, and central foloriul

- ipecies 22

Koyukuk River. I laska. lat. $67^{\circ} 69^{\prime}$. long. $151^{\circ}$

species 23

Sorthern Michigan

species 24

Coluradu and Ctah ....

ripecies 25

Mount Rainier. Washington

Maine to Northern Mirhigan

speries 26

speries 27

llishor mountains of Diorth fareblina.

syeries 28

11) ISI(). 11

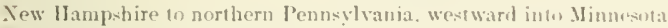

speries 29

Kiaslu, British (')lumbia .

speries:30

\section{TABLE SHOWING RELATIONS OF SPECIES TO HOST TREES.}

rissodes

$1 \operatorname{los} 2,1+1 \mathrm{c}$

speriey

numlw-rs

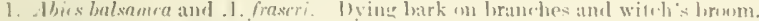

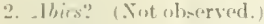

3. Jicra sitehrmis? Int observed.)

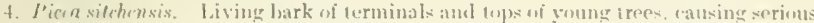
iujury.

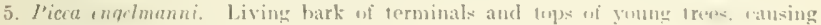
keriusus injury.

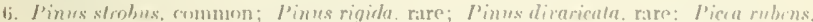
frequent: Jima trelst. frequent. livime terminals of saplines amb sm:1] trees. ("an-ing serimu rlamawe? to white pime

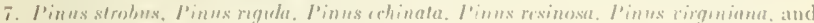

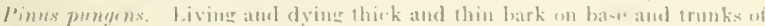

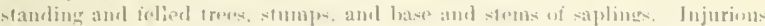
(1) 1 he. la -1 .

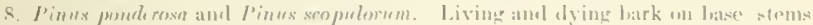
(1)p $(?)$, and forminals of sajplings.

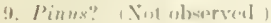

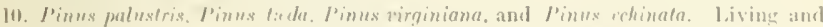

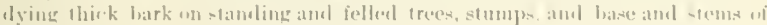
Naplingr-s.

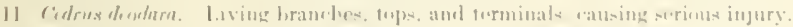

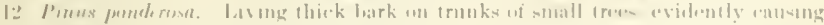
Marar.

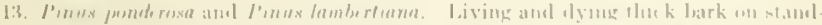

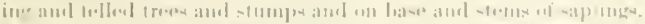

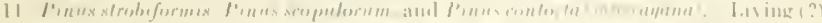

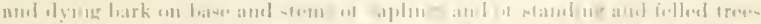

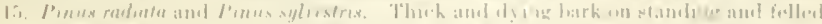

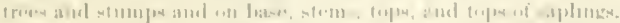

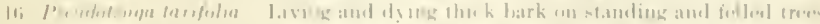

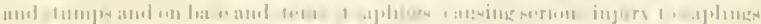

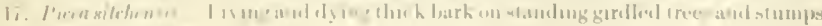
ii $\{1 \mid 1,4]$ แ16. . 
18. Picca rubens and Picca marima. Dying (?) thick lyark on logs, stumpes, and trunks of small standing trees.

19. Picca mariana. Dying bark on trunk of small tree.

20. Picca rubens. Dying bark on felled and standing trees.

21. Pinus contorta (murrayana). Thin bark on standing tree.

22. Picea canadensis and Picca engclmanni? Dying thick bark on hase of standing trees.

23. Picea. Thick bark on living trees. (Brunner's notes.)

24. Probably in Picea rubens? and Picca canadensis? (Not observed.)

25. Abies lasiocarpa and Abies concolor? Living thick bark on trunks and laase of living and dying trees. Injurious.

26. Abies lasiocarpa and Abies concolor. Living and dying thick bark on living and dying trees.

27. Abies balsamea. Living and dying bark on trunks of living and dying trees and snags of storm-broken trees; also in trunks of felled trees.

28. Abics frascri. Living and dying bark on trunks of living and tying trees.

29. Pinus strobus. Thick bark on stımp.

30. Host not observed; probably pine.

TABLE OF HOST TREES.

Tree species.

(Britton classification, 1908.)

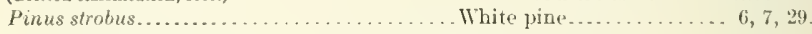

lambertiana..................... sugar pine............ 13.

strobiformis..................... Mexicau white piue...... 1.1.

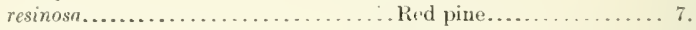

ponderosa.................... Western yellow pine...... 8, 12, 13.

scopulorum . . . . . . . . . . . . . . . Rock pine............. s, 14 .

murrayana.....................Lodgepole pine........ 14, 21.

palustris.................... I. ngleaf pine . . . . . . 10.

rigida. ................... Pitch pine ........... 6,

chinata..................... shortleaf pine......... $7,10$.

txda......................... loblolly pine........... 10.

radiata. ..................... Mnterey pine . . . . . . 15.

banksiana (divarieata) ........... (iray pine ..........

virginiana................... Virginiat or scrub pine.... 7. 10 .

pungens..................... Table mountain pine.....

syluestris (introduced) ............ Silver pine . . . . . . . 15

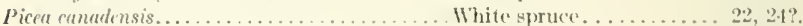

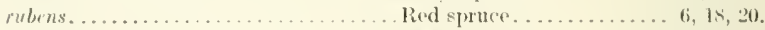

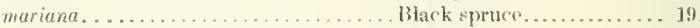

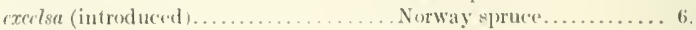

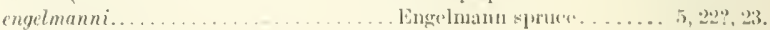

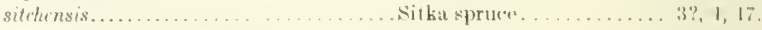

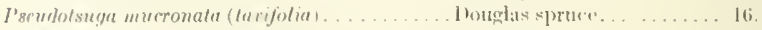

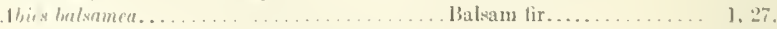

fiasiri.....

lasuocurpa.

concolor.

Frasier's balsam fir...... 1, 2S.

White fir. . . . . . .

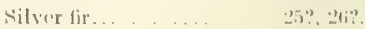

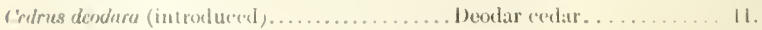




\section{CHARACTERS COMMON TO THE SPECIES OF THE GENUS.}

Adults.-Prothorax with anterior ventral margin not istinctly emarginate: tibix with incurved apical tooth; femora unarmed; anterior coxar not widely separated: aldominal tergites covered by elytra: sternites 3 and 4 (first and second visible) very long: 5 and 6 short; 7 as long as 5 and 6 together; eyes romeled, widely separated: body oblong, redklish brown to black. sparscly to thickly "lothed with slender to broad seales, the latter often forming spots on the pronotum, elytra, and femora.

Sexfs.-Females with but 7 visible ahdominal tergites; beak longer, smoother, and more slender than in the males. Males with $s$ visible ablominal trergites; beak shorter, stonter, less shining, and more distinetly punctured.

Eggs. Pearly white, slightly oblong, and equally rounded at both ends.

Larrar.-Elongate, "ylinelrieal, vellowish white, fontless; holy with 12. closedy wrinkled secgments, those of the thorax not larger or more permanent than the first abdominal.

Pupa. Of the general size und form of the adults, with the beak foldeal on the mesosterna and metusterna; tips of the posterior tarsi even with tips of wing-pads; lead, heak, and abdominal serments armed with spines, the ninth ahelominal having - rather prominent epipleural spines.

Lareal gallerirs.-Exalvated in the inner bark and sometimes marking or grooving the surface of the wood: elongate, winding, and either in the hark or onter wood, anding in pupal eells which ner lined with excelsior-like borings.

Ilost trus.- I'inus, P'icta, Abies, Cirlrus, and Psondotsuga.

Jistribution. Sipain and England into enstem Siberia and Japan; Amerien north of Mexico.

\section{CHARACTERS COMMON TO THE SPECIES OF THE MAJOR AND MINOR DIVISIONS.}

\section{MINISIM!}

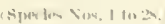

Adults. Elytmal interspaces 3 and is hroulex and more elernted than 2 und 1 .

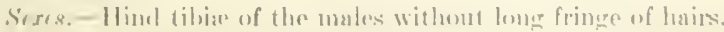

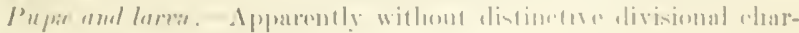
are(1.rs. si) fur as ulservert. 


\section{STBHTISION $\mathrm{A}$.}

(Specit's Nos. 1 to 1ti.)

Adults. - Elytra always with a distinct spot of densely placed scales on the anterior lateral area, and always with a spot or band of seales near the rertex of the declivity.

Sexes.-Beak of both sexes ustrally shorter than the prothorax, rarely longer.

Pupa. Eyes with one or more minute spines on the posterior margin.

Larex.- The sublivisional characters of the darva have not been recognized.

$$
\text { SE(TIIN) aI. }
$$

(Species Nos, 1 fu 14.)

Adults.-Elytra with distinct spots (instead of a rontinuous band) near the verter of the dectivity.

Sexes.-Apiagl margin of the seventh alxhominal sternite of the male not sinuate, or rarely so.

Pupd.-Ilulominal trogites with small scutellar spines, alternating with larger ones.

Lamæe.-Median tooth of mandible emarginate.

Ilost tress.-1bies, Picere, Pimus, and Cedrus.

Distribution.- Fastern and western Lnited States, from the Gulf States and Mexico into Canasla and British Colmmbia.

SUBNECTION hl.

(Species Nos. 1 to 3. )

Adults.-Bork moderately stout, shorten than the protherax; basal angles of pronotum subobtuse; thiret and lifth olytal interspaces strongly elevated and ruguse. In sperose 1 and 2 the anterior sposts on the elytra are distinet, the pesterior ones are rery latere, and the

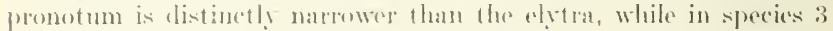
tho anterior and posterior spots are imblistinot and the promotum is mot distinetly narewere than tho olytra.

Strex. Aproal margin of seventh abdominal sternite of male not imarcrinate.

Host trese. Ibiss, so lay as observerl.

Jistribution. Fipecies 1, Nonth Carolina: spectes 2, British Colum-

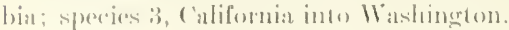

\section{Pissodes similis n. \&}

(Plate 111, lik. I.)

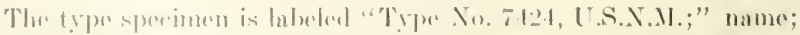

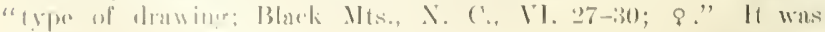

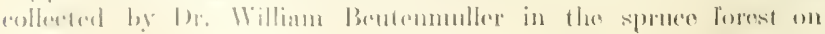


Black Iountain, Nortl Carolina, in 1905. The type and one male are in the type collection of the U. S. National IIuseum. Three females and one male from the saune locality, labeled, respectively, "VI-17," "VI-17," "VI-19." and "VI-30," were leturned to the American Juseun of Natural llistory, New York (ity. A dead specimen was collected by the writer at Camp Caribou, Maine, June 7, 1900, on tleal branch of "witch's broom," on balsam fir. Larval mines and pupal rells were observed in aljoining twigs, and another dead specimen was taken at Waterville. X. II., Мay 4, 1906, from a pupal cell in aleal brancle of "witch's broom." on lalsam fir. Several specimens had emerged from the same branch.

Distinctime characters. - This specie's is closely allied to $P$. utakensis, from which it is distinguished by the molerately coarse pronotal junctures and the very large posterior spot which extends anteriorly to the midelle of the elytra, and is sumpounded by a distinct dark border.

Variations.-The sperimens vary in length from 3.7 to 4 mm., and in color from light brown to dirk lorown, witl but slight varintion in the spots. Eirht arlult specimens were examinerl.

Ilost trees.-Abies balsame; 1bies fraseri.

Distribution (Plate XIX, fig. 1).-(1lopk.C.S.) Mains: Cump Caribou, Parmachene Lakn. New Inmpstrim: Waterville. (A.У.X.IT.) Worth Carolina: Black Nomutains.

\section{Pissodes utahensis $n$. . $\mathrm{l}$.}

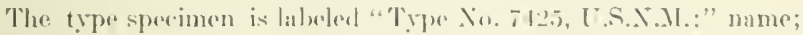

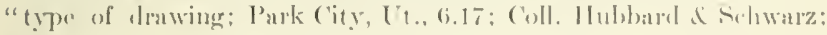
95); ; 1 ."

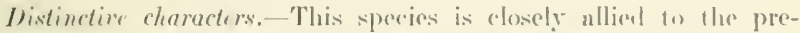
cerling, from which it is atistinguished lye the roarser pronotal punce-

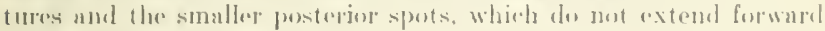

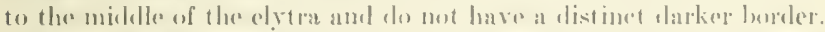

Tariation. There is very lithle varintion in size, hut the sasles vary from white to a gellowish lowwn. Five alult spermens, of

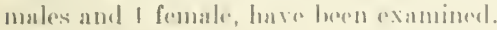

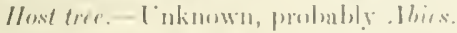

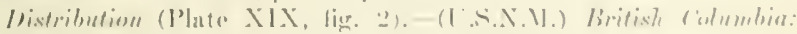

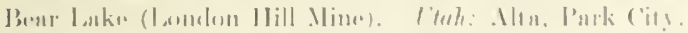

\section{Prasodes briberi "।}

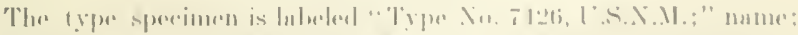

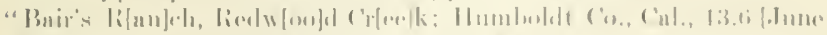

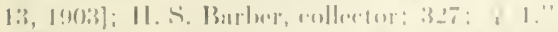

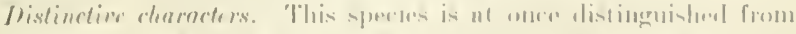

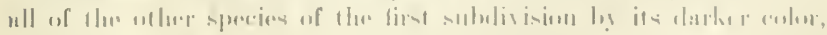

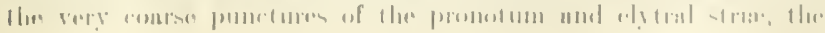


strongly elevated and acutely rugose third and fifth interspaces of the dytra, and the small posterior spot. The pronotal punctures are also more distinctly separated than in the other species.

Varations.-There is some variation in size-the length ranging from $5 \mathrm{~mm}$. to $5.5 \mathrm{~mm}$.- and in the elytral spots, color of scales, ete. Three adult specimens, 1 female and 2 males, have been examinerl.

Host tree.--Unknown, probably Picea.

Distribution (Plate XIX, fig. 3).-(U.S.N.M.) Californio: IIumboldt County. Oregon: Astoria. Washington: Tenino.

Subsection b2.

(Species Nos. 4 to 14.)

Adults. - The beak is slender and shorter than the prothorax in some species and longer in others. The basal angles of the pronotum are rectangular but not acute. The third and fifth elytral interspaces are moderately to strongly elevated and rugose. Species 4 to 6 have large anterior and posterior spots on the elytra. The sides of the elytra are parallel and the beak is never longer than the prothorax. Species 7 to 14 have small anterior and posterior spots on the elytra; the elytra are slightly narrowed anteriorly and the beak in some of the speeies is longer than the prothorax. Species 9 to 12 lave the third and fifth interspaces of the elytra distinctly elevated and broader than the second and fourth, and the punctures of the pronotum are moderately coarse and densely placed. Species 13 and 14 have the third and fifth interspaces of the elytra only slightly broaler than the seeond and fourth, but strongly elevated and acutcly rugose. The pronotum is distinetly narrower than the elytra and the pronotal punctures are very coarse.

Sexcs. In sperirs 4 to 6 the beak of the males is shorter than the thorax and that of the females is rarely longer, while in species 7 to 14 the benk of the males is as long as the prothorax, and in a few cases longer; that of the femaless is usually longer and often distinctly so.

Pupx. The fifth and sixth alulominal tergites of species 4 amd 6 have small spines between the prominent dorsal ones, while in species 5 and 7 to 14 they are olsseure or alsent.

Larve.-The apical tooth of the mambilbles is acute and the abdeminat spiracles are distinct. In species 4, 5, and 7 to 10 the eye spotis are distinct, while in species ti and th they are not.

llosts. Speries 4 and 5, Picen: species t, P'inus und Picor; species 7, s, 10, and 1:2 to 11, Pimus; species 11, Cedrus.

Mistribution. Species 1, Rocky Mountains; species 5, Pacifi. const; species li and 7 , eastern Lnited States; species 8 , northern Rocky Mountuins; species 9, canaln; speries 10, 11, Soutbern Stutes; species 1:, 13, ('uliformin; speries 14, southern liocky Momtuins. 
4. Pissodes sitchensis $\mathrm{n}$. = 11

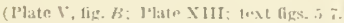

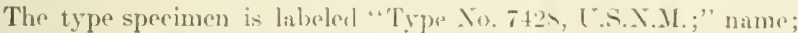
"Hoquiam, Wash.; II. E. Burke, eollector; \&; Ilopk. I. S. s.2s!)e." The species was deseribed from a large series, ineluding all stages, work, and parasites, eollected and reared from terminals.

Distinctive charactors. - This specios is closely allied to P. ngermanni and $P$. strobi, from the first of which it is distinguished by the subopaque pronotum, the absence of lark lamel on the posterier spot of the elytra, and the rather coarse punctures of the elytul strix; from the latter it is distinguished hy its atrerage smaller size and narrower prothorax, as well as by its distribution and habits.

Taviations. - There is not very much valriation in size length 5 to $5.3 \mathrm{~mm}$. The color ranges from light to dark brown. The spots of scales vary in size, color, and density, and there is some varintion in the relative width of the prothorax and in the size of the punctures of the elytral strix. More than 2 (no sperimens latve bern eximined, incluling both sexes, larra, pupa, and work

Host tre.- Picra sitchensis, jufesting tops and terminals of saplings: and small trens: quite injurious.

Extensive observat ions hawe been mate lyy Mr. Burke on the habits ant seisonal listory of this species.

Distribution (Plate XIX, fig. 1). (llopk. L. S.) Omgon: Asturiat.

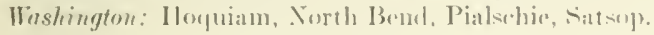

\section{Pissodes engelmanni $\mathrm{n}, \mathrm{s}$ ?}

IIlak, VI, fig, :

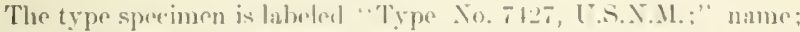

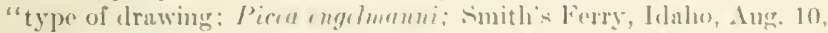
'05; J. L. Webb, collector; 3 ; Hopk. U. S. 5314." From a siries

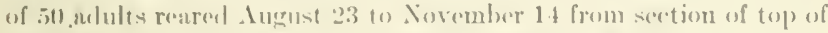

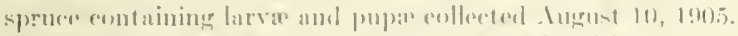

Distinction chatacters. - This species is distingui-lied from the precerling in that the proustum is shinieg, the presterior spot of the

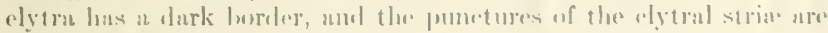

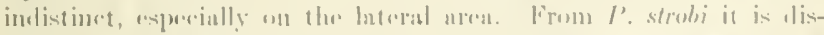

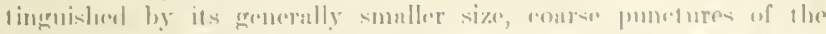

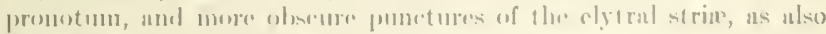

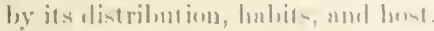

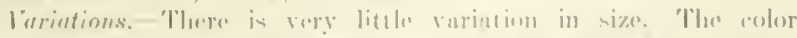

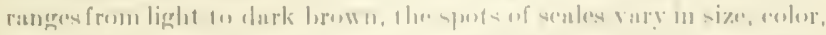

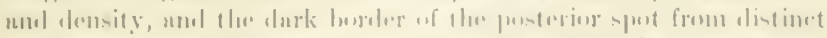

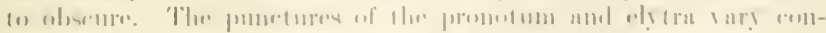

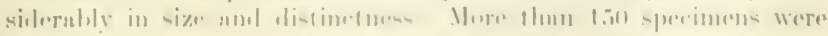

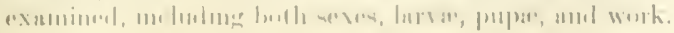


Ilost tree.-Picea angelmanni, inlesting tops and terminals of saplings and small trees; quite injurious.

Extensive observations on the habits and seasonal history of this species have leen made by Messrs. Burke and Webl.

Distribution (Plate XIX, fig. 5).-(Hopk. [Y. S.) Colorndo: Manitou Park. Idaho: Smiths Ferry. Montana: Little Belt National Forest.

\section{Pissodes strobi Peck. .}

(Plate 1II, fig. 6; Plate VI, fig. t; Plate XIV; text figs. 1, 2.)

This species is represented in the eollection by a typical specimen labeled with name, "type of drawing: Pinus strobus; Webster, N. H.; W. F. Fiske, collector; \& 6; Hopk. L. S. 3215b;" by 2 specimen. labeled "Pinus strobus; Milford, Pa.; 1. D. Hopkins, Nov. 14-25, bred; Hopk. U. S. 6077," and by one small specimen labeled "Edsallville, Pa."

Distinctive characters. -This species is most closely allied to $P$. engetmanni, from which it is distinguished by its average larger size, dense punetures of the pronotum and distinct punctures of the elytral strie, its well as by its distribution and labits.

Tariations. - There is considerable variation in size 4.5 to $6 \mathrm{~mm}$. in length-but the average is nearer the latter extreme. The color ranges from dark to light brown. The spots of seales vary considerably in size, density, and color and in the presence or absence of a clark border to posterior lateral spot of the elytra. There is also considerable variation in the form of the pronotum and in the punctures of the pronotum and elytral strice. More than 500 specimens were examined, including all stages and work.

IIost tress. - P'inus strobus, Pinus rigida, Pinus livaricata, Picca rubens, and Piern acelse: infesting terminals. Very injurious to white pine, much less so to the other species.

Distribution (Plate XIX, fig. 6),-(Iopk. U. S.) Connecticnt: Ilartforl, Pomlinet Center. Ihaine: Alfred, Bangor, Portand. Massarhusett: Framingham. Mehigan: Grand Rapids. Vew Ilampshive: Colelnook, Dover, Franconia, Keene, Monadnock, Nowport, P'nacook, Pike, liochester, 'Tamworth, Wedster, Wirs. New York: Kiamesha, Kidders. Vorth Camolina: Biltmore (1)avidsons River). Pennsyluna: ("isunrun. Milford, Mount Liry (Franklin ('ounty), Truckstille, Wilkesharre. West Tirginiu: Kunawha

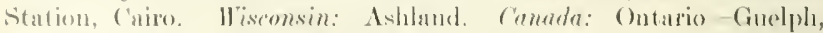
()ttawn; Now Brunswick ('hatham, Frederickton. (Hopk. W. Ta.)

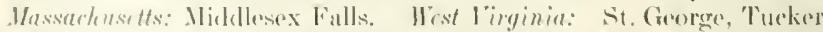

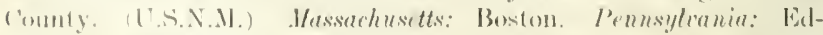

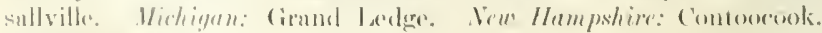
New Yort: New Baltimore. 
Rhynchanus strobi Perk, 1sli, p. 2, pl. 2. Harris, 1841. pp. 4i3-4i4.

Pissodes strobi (Peck) say, 1531, p. 14 (in part). Fitch, 1sis, Pl). 732-736, pl. 3, fig 1. Say, 1859, p. 277 (in part). Walsh and Riley, 1869, p. 26, fig. 2.2. Gemminger and Harold, 1871, p, 2432. Le Baron, 187.1, p. 139, tig. 63. Thomas, 1876, pl. 133-134 (in part). Le Conte, 1876, pp, 142-143 (in part). luller, 1880, pp. 5-ti, fig. 2. Saunders, 1853, p. 55, fig. 23 (in part). Packart, 1886, pp. 322-325, pl. 9 (in part). Jintner, 188s, p. 24, figs. 6, 7. Packard, 1890, PP. 731-741 (in part). Riley and Ilowart, 1490, J. 348 (parasite); 1891, p. 46t (in part). Jintner, 1893, pp. 344-3.5), fig. 22 (in parl). Hopkins, 1893, p. 205, No. 219 (in part); 1899,1 '. $259-260,345,141$ (in part). ('hittenden. 1899, p3. 58-59, figs. 11, 12 (in part). Felt, 190t, pp. 397-t01 (in part). Hopkint, 1906, pp. 252-253, figs. 61, 62; 1907, pp. 1-7, ligs. 1-6; 1909, pp. 11, 16, 17, figs. 8, 9.

\section{Pissodes approximatus n. ep.}

(Plate VI, fig. $i$; Plate XV, figs. A, B.)

The type speeimen is labeled "Type No. 7t30, L.A.N.M.:" name; "Pinus strobus: Lynn Woods, Mass.; A. D. IIoplins, Jnue 11, 06. bred; \&: Jopk. L". S. 6332." This specimen was reared from larre in bark from hase of white pine sapling defoliated by the gipsy moth. The type series is represented by a male labeled the same as the type, one labeled "(amb.; (oll. IIubbard \& Schwarz; to," and 2 males labelerl "Marquette, Mich., 27.6: Coll. Hubbarel \& Schwarz."

Distinctire characters. This speeies has been commonly confused with $I$ '. strobi in collections and literature, but is distimguished from it hy the average large sime. elougate body, the sides of the elytra more elistimelly nurowed posteriorly. The benk is longer, and the spots of the alyta are uniformly smaller, the posterior ones rarely romected. It is also definituly separated hy its marked differene in lonbits. It is distimgnisherl from $P$. memorensis, (1) which it is

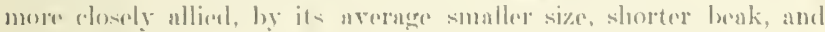

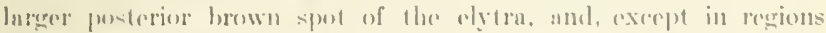

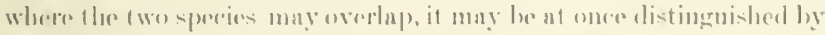
its distrilsution. It iv distinguisherl from its closest ally, I'. schuarzi,

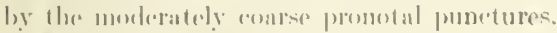

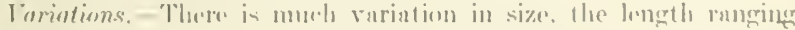

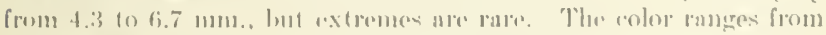

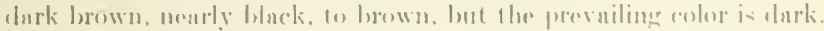

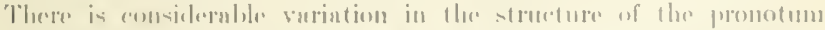

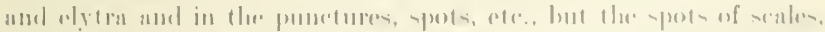

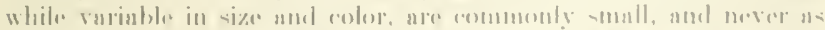

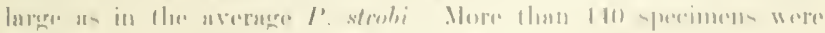

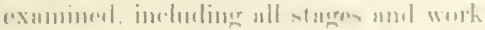

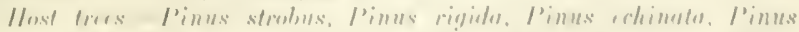

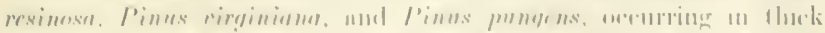

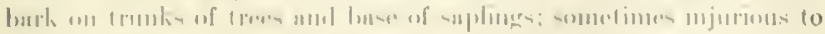
the suploric 
Distribution (Plate X.IX, fig. 7).-(Hopk. U. S.). Maine: Lake Moxie. Massachusetts: Lynn Woods, Springfield. Michigan: Grand Island, Munising. New Ilampshire: Penacook, Waterville, Webster. North Carolina: Biltmore, Ilendersonville, Pink Beds. Pennsylrania: Milford. Tirginia: Rock Springs. Wisconsin: Lac du Flambeau. Canada: Guelph.

(Hopk. W. Va.) West Tirginia: Deckers (reek, Greenbrier County, Greene Spring, IIampshire County, IIarpers Ferry, Morgantown, Pendleton County, Romney, Tibbs Run, Tucker County. (U.S. N.M.) Massachusetts: ('ambridge, Marion, Springfield. Michigan: Eagle IIarbor, Marquette, Whitefish Point. Neu Ilampshire: Durham, IIanover. New York: New lork City and vicinity. Wisconsin: Bayfield.

\section{Pissodes schwarzi $\mathrm{n}, \mathrm{sp}$.}

(Plate III, fig. 8; Plate $\mathrm{XVT}$, fig. B.)

The type specimen is libeled "Type No. 7455, I.S.N.M.;" name; "Veta Pass, Col. 24.6; (oll. Hubbarl \& Schwarz; ?." This, together with another specimen, a male from the same locality, was evidently collected by Mr. E. A. Schwarz, for whom the species is named. The specimens were found in the United States National Iluseum under 1 ', costatus.

Distinetive characters. - This species is eviclently confused in collections under the name $P$ '. costatus. Specimens of $P$. schwarzi and $P$. yosemite had been referred to $P$. costatus hy the writer until the specimens from sitka sprum were recognized as representing the latter. With possibly a single exception, the specimens referred to by Le Conte under $I^{\prime}$. costatus avilent\}y belonged to $P$. yosemite. $P$. schurari is not allied to the specimens I have referred to $P$. costetus. In general appearanee it comes nearer $P$. yosemite and P. wobbr, but according to the character of the lork of the male genitalia it falls in the series with $l$ '. approximatus, from which it is distinguished by the narrow pronotum with eoare punctures and loy the larger posterior spots of the clytra. It is distinguished from l'. urbbi hy its relatively broalder pronotum, the punctures of which are less coarse and more densely placed, and from $P$. yestmite hy the same character; also it is distinguished from both by its clistribution.

Tariations. - There is quite a wicle range of variation in size, the length ranging l'rem 5.2 to $6.7 \mathrm{~mm}$., and in the density of the pronotal punctures, size and lensity of spots of seales, and relative olevation of clytral interspanes 3 and 5, so that some specinens may be foumel which appear to connect it with the other species, but it is the writer's opinion that when we know morer of the labbits and seasomal

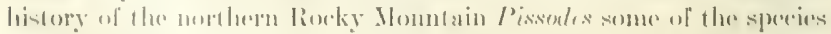

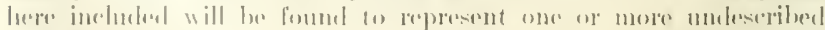

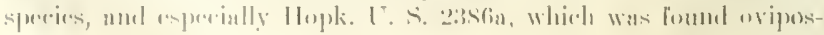


iting in the terminal of a pine sapling. Forty-nine specimens have been exanined, including all stages and work.

Host tree.-Pinus ponderosa scopulomem, in thick bark on trunks of trees, in base of saplings, and possibly in lops and terminals.

Distribution (Plate XIX, fig. S).-(Hopk. U. S.). Colorado: Estes Park. Idaho: ('enterville. South Inakoto: Black Hills, ('uster, Jead. Washington: Buckeyr (T.S.N.M.) Colorado: Breckenridge, Estes Park, la Veta Pass, Leadville. Montana: Helenn. South Dakota: Custer. Washington: Buckeve. Canada: Alberta, Bunff Springs.

13ВLIOGRPHY AND SYNoNYMY

Pissodes costalus (not of Mann.) Hopkins, 1906, p. 254, fig. 63.

๑. Pissodes canadensis 11. sI'.

The type specimen is labeled "Type No. 7431, [T.S.X.M.;" name; "Winnipeg, Man[itoba], Ilanham; ? 1." This, with two other specimens, a male and a female, were found in the Wickham collection in the Inited States Sutional Museum under P'. strobi.

Distinctive characters. - This speries may be masily confused with $P$. approximatus by its general external appearance, but the differcuce in the fork of the male genitalia incliontes that it is listinet and more nearly related to $I^{\prime}$. nemornsis, It is distinguisherl from P. approximatus by the somewhat stouter bouly and prothorux. The ulternate interspaces of the elytra are acutely rugose, the pusterior spots are more completely fused on the hateral area, and the beak is longer. It is easily separuted from l'. nemorensis by the relatively shorter beak and stouter body and fused posterior spots of the elytra, us nlso by its distribution.

Tariations.- There is not much variation in the thres sperimens except that the altermating elevated intersponces are less acutaly rugose in one specimen than in the other two sperimens. Theres adult specimens were eximined.

Ilost tres.- Not knewn, lut it is evidently pine.

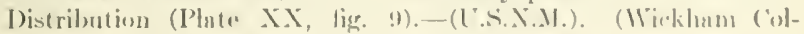
lection) ('anada: Mastitubu (Winnipeg).

\section{Pissodes nemorensis (irmar}

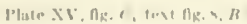

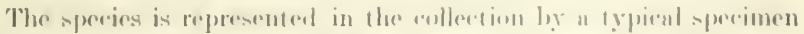

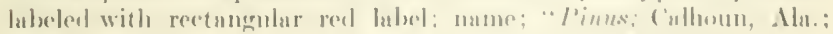

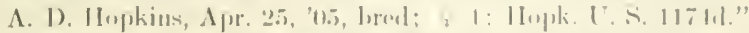

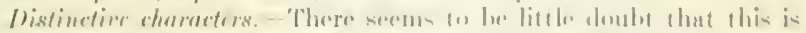

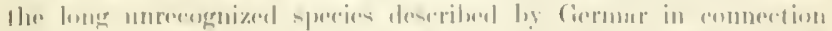

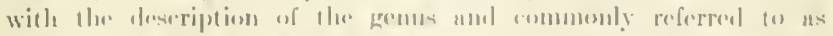

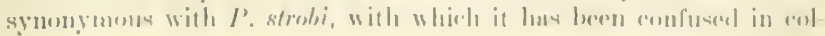


lections and literature. The reference in the cheseription to the beak being longer than the prothorax is suffieient to distinguish it from $P$. strobi, and the type heality, "Kentucky," is sufficient to place it. within the range of this common southern form. This species is very readily distinguished from $P$. strobi by its average larger size, much longer beak, smaller spots of scales on elytra, and by its habits and general distribution. although the ranges of the two species may overlap in some places. It is distinguished from $P$. approximatus (with which it may oeeur in the Transition zone around the Appalachian 1 lountain ranges) by its average larger size, longer beak, the elytra more distinctly narrowed posteriorly, and much smaller posterior brown spot. It is also distinguished from its rlosest ally ( $P$. deodare), the only other species known to ocenpy the Gulf States region, by its arerage larger size and shorter beak, and by the posteriorly narrowed clytrat and more distinctly elevated third and fifth elytral interspaces.

Tariations. - There is much variation in size, the length ranging from 4.9 to $7.7 \mathrm{~mm}$., and in color from nearly black to light brown, the darker areas predominating. There is also much variation in all of the structural and sculptural characters and in the size, density, and eolor of the spots. More than 250 specimens have been examined, including all stages and work.

Host trees. - Pinus palustris Pinus tada, Pinus virginiana, and Pinus chinata, in thick batr on trunks of dying and felled trees, stumps, stems, and base of saplings, ete. Apparently it is not esperialty injurious.

Distribution (Plate XX, fig. 10).—(Hopk. U.S.) Alabuma: Callorum. District of Columblia: L Langrdon, liock Creek Park. Creorgia: Demorest, Maron, Thomasville. Maryzund: Silver Spring. North Carolina: Boardunan, Tryon. South Carolina: Lumber. Texas: 1)eweyville, Honston, Vimgina: IIawlin, Princess Anne County, Virginia Beach. Wrst Tirginia: Kimawha Station. (Hopk. IV. Var.)

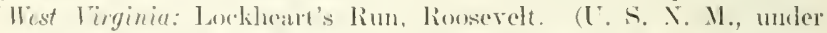
I'. strobi.) Habuma: P'rattvilte. Floridu: Tallahassee. Ifraryland: Piney Point. North cirrolina: Recteat, Graybeard Mountains.

BHHLGRAPHY AND S'YNONYMY,

l'isnots: nemoronsis (iermar, 18:4, 1, 318. (ienminger and 11:arold, 1871, p. 2431. l'issorles strobi (not of l'eck) Saly, 1831, J. I.1 (in part). Ilarris, 1s.11, 1). 63 (in part).

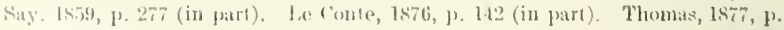

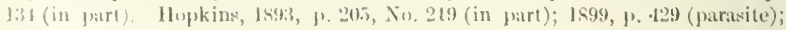

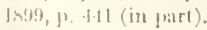

11. Pissodes deodaræ U. \& s .

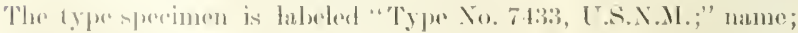

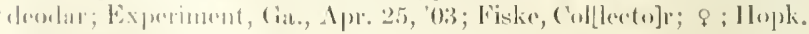
1... $16111 \%$ 
Distinctive characters. - This species is distinguished from $P$. nemorensis by its average smatler size, lonerer beak, less distinctly elevated elytral interspares, and the sides of the elytlia more distinctly parallel, but it is more distinetly sepalated by its hat hit and host. It is not improbible that this is an eximple of the origin of species through mutation and change of halbit and host.

Tariations. - There is consiclerable variation in size, the length ranging from 4.2 to $5.8 \mathrm{~mm}$., but there is unt rery much rariation in the grayish-bromn color or in form. sempture, and restiture. In fuct, it appears to be more constant in generial rhatioter than almust any of the other species.

Hest trer. Fedrus deodera, in living loranclues, tepse, and tominals, causing serious injury.

Distribution (Plate XX, fig. 11).-(Itopk, I. . .) reorgia: Experiment.

\section{Pissodes californicus n. sp.}

The type specimen is labeled "Type No. 7456, L. S. X. M.:" name; "Pinus ponderose: Yusemito Val., Cal., lune 13, "04: 110pkins, Col[lecto]r: \& 4; Ilopk. I'. S. 2sosta." This sprecimen was collected by the writer" at the same time and plares as thase referred to $I^{\prime}$. yosemite, and was not recognized at the time as distinet.

Distinctive characters. This speries is elesely related to I'. nemor-

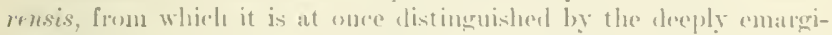
nate unterios margin of the proustum and by its very dillerent habit and elistribution. It is also readily distinguished from $l$ '. gessmite by the brobl, closely puntured promotum with its emarginate

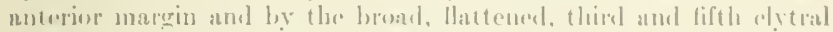
intersplatess. Inderest, it is se markedly diflerent from any of the

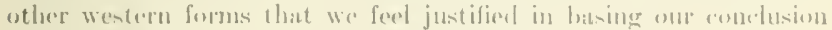

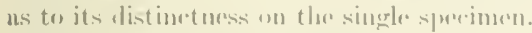

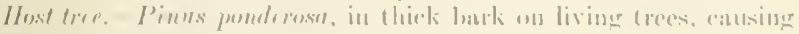
strims sims.

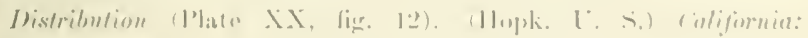
Jescenite Vialley.

\section{Pissodes yosemite $n$ n}

I"latn $x \mid 1$ fis. I.

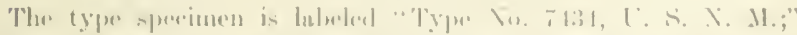

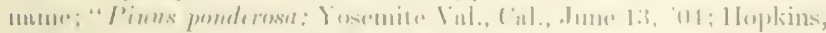
(

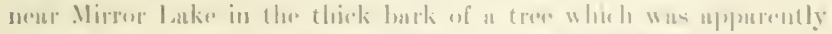

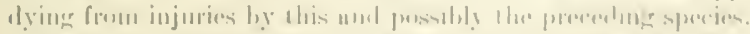

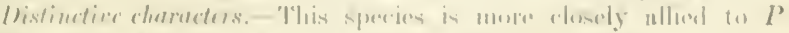

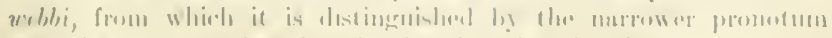

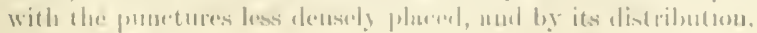


Tariations.--There is considerable rasiation in size, the length ranging from 5.1 to $7 \mathrm{~mm}$., but not much in its reddish-brown color. The spots of whitish scales are usnally conspicuous on the sides of the pronotum and near the declivity of the elytra, but there is considerable rariation in their size, density, and color. The very coarse punctures of the pronotum and the strongly elevated third and fifth elytral interspaces are quite constant and characteristic. Fifty-ome specimens were examined, including adults, larrat, and work.

Ilost trees.-Pinus ponderose and Pinus lambertiana, in living and dying thick bark on standing and felled trees, stumps, and base and stems of saplings. It is evidently quite injurious.

Distribution (Plate XX, fig. 13).-(Hopk. C.S.) California: Summerdale and Yosenite. (L. S. N. M.) California: Lake Tahoe, Placer County, Siskiyuu Comty, under P. costatus. Washington: Easton, under $P$. fusciatus.

\section{BIBLIOGRAPHY AND SYNOXYMY}

Pissodes costalus (not of Mannerheim) IJopkins, 1906, p, 254, fig. 64.

\section{Pissodes webbi n. sp.}

The type specimen is labeled "Type No. 7459, U. S. N. M.;" name; "Pinus strobiformis; Jned Nor. 12-7; Stal. Catalinal Mts., Ariz.; J. L. Mobls, collector; \&; Iopk. L. S. 5722." The sprecimen was reared with other's liom larve in thick bark on small felled tree, Augrust 20, 190s. It is mamed for the collector.

Distinctive charecters. - This species is more closely allied to $P$. yosemite, from which it is distinguished by the broader promotum, with 1 loc punctures more chosely placed.

Tariations. There is ansicleriblule variation in size, the length ranging from 4.S to $6 . \mathrm{S}^{\mathrm{m}}$ mm., and in color from nearly hlack to dark redelish-brown. There is less vartation in the spots than usual, which have less white and more of the yollow stalles. Over 70 specimens were examined, inchuting all stanes and work.

Jost tress. J'inus strobiformis, Pinus scopulomem, amd Pinus murelyome (contorta) in liviugr ? ) and dying bauk on base and stems of saplings and standing and folled troos. It is probably injurions.

l)istribution (Plute XX, lig. 11). (Hopk. L. S.) Jrizonu: Santal

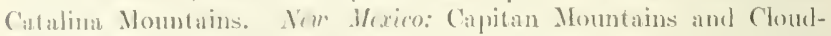
('inlt.

Bmblomkaphy ann Sirgongat.

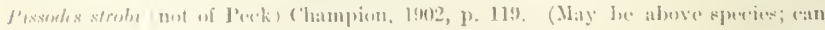
nut le. I' stong l'erk. - I. I) II.) 
SECTION 32 .

SeBSECTIONS b3 AND b4.

(Species Nos. 15 and 16.)

Adults.-Elytra with a transverse band of white and yellow scales insteal of a tistinct spot near the vertex of the declivity; heak shorter lhun the prothorax. Syeres 15 has a broat pronotum with the posterior angles arute, while in species 16 the pronotum is narrow and thr angless subrectancrular.

Sirss.- Ipical marina ol seventh ablominal sternite of males not simute; heak sliwhty lonero and more slenter in the females than in the nale's.

Iupa. - Iblominal tergites without distinet small spines alternating with the lontrer ones. species $1 . j$ has distinct epijulenral spines, while speries 16 does not.

Jarre. Eye spots distinct; apical tooth of mandible obtuse in spereies 15 und acute in species 16 .

Ilosts. - Spreies 1.5, J'inus; sper.ies 16, Psumlotsuga.

Jistribution.- Speries 15, eoust of California and Washington; specoies 16, northern ('alilomia info Britislı Columbia.

15. Pissodes radiata n. sp.

Place ill, fig. 1.5.)

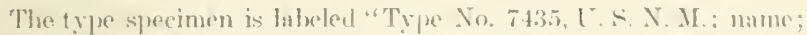
J'inus; Del Monte, ('al., Sept. 1, '02; A. D. Hopkins, collereter; \& 1;

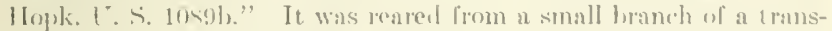

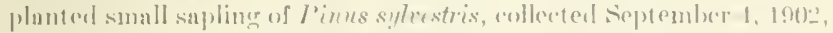

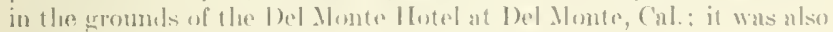

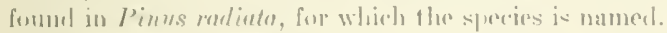

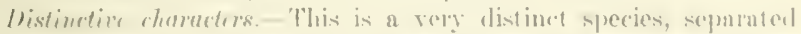

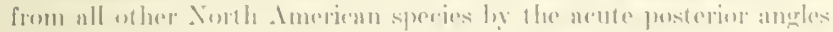

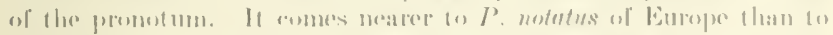

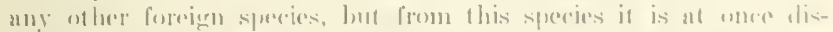

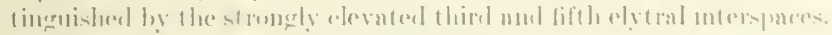

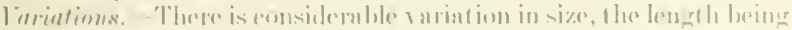

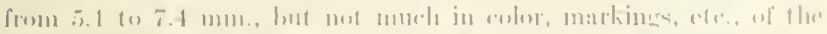

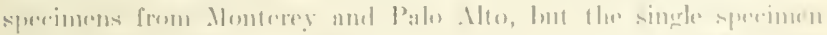

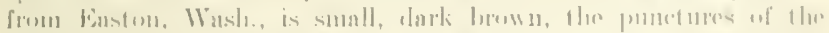

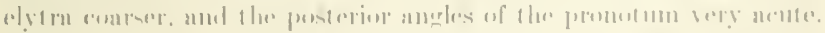

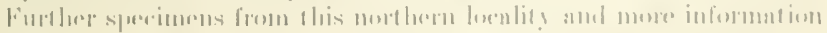

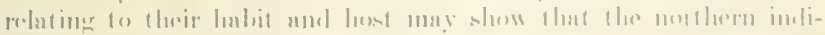

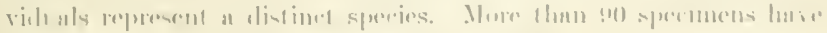

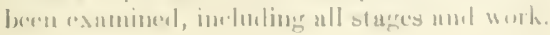


Host trers.- Pinus radiata (common) and Pinus syliestris (rare), infesting the thick bark on standing and felled trees and stumps, and the base, stems, and tops of saplings.

Distribution (Plate XX, fig. 15).-(Hopk. I. S.) (atifornia; Del Monte, Monterey, Palo Alto. (U. S. N. M.) Washington: Easton, under $P$. fusciatus.

\section{Pissodes fasciatus Je Conte.}

(Plate 11I, fig. 10; Plate XIII.)

The species is represented in the collection by a typical specimen libeled with the name "type of chawing: Psentotsuga tarifolia; Hoculam, Wash.; Burke, col[lecto]r; ؟ ; Hopk. I. S. 2064b."

Distinctive characters.-This species is reaclily distinguished from $P$. radiatx, to which it is somewhat remotely allied, by the posterior angles being rectangular instead ol aente, the third and fifth interspaces less elevated, and also by its labit and host.

Tariations.-There is consiclerable variation in size, from 5.1 to $\$ .3$ $\mathrm{mm}$. in length, and in color from nearly black to reddish and brown; there is also much rariation in the size, density, and color of the spots of' scales. More than 200 specimens liave been examined, including all stages anil work.

Host tree-Pseudotsuga taxifotia, living and dying thick bark on standing and felled trees and stumps, and on the base of saplings.

Distribution (Plate XX, fig. 16).--(Hoy)k. I. S.) Wishington: Aslıford, Leyport, Hoquiam, Meredith, Pialschie. (Weblis collection) Washington: Sequim. (U. S. N. M.) Hashington: Tenino, Easton. Oregon: Corvallis, Portland. British Columbiu: Linslo, North Bend, Victoria.

Biblogiafiry.

Pissodes fasciatus Le Conte, 1876, 1] ]. 142-I43. IIopkins, 1905, p. 253, figs. 65, 66.

\section{जIBHVISION B.}

(Hiperies Nos. 17 to 28 .)

Adults. Elytra usually withont distimet spots on anteriol lateral area und with small spots situated between the vertex of the declivily nod the median atrat.

stres. Beak in both sexes rarely shorter than prothorax, commonly much longer, and always distincely longer in females than in maless.

Papre- Lyes without minute spines on posteriop margin (wo lar as a)sicteds).

latrex. Withont distinctive divisoual rharacters (so far as (1)八erveris).

Ilosts. Licra rul Abies. 
Distribution. -Sertion a.3, coast of western Washinutun to Sitka: section 14, (alladian zone, eastern [nited States from mountains of North Cirolina to Canada, and northern Rocky Mountains and Pacific Coast region northwarl into Alaska.

\section{SECTION a3.}

(Species No. 17.

. drults. - Basal angles of promotum subrertangnlar and beak rather stout and moderately hong; apical margin ol the seventh abdominal stemito of male without apical process, but faintly sinuate.

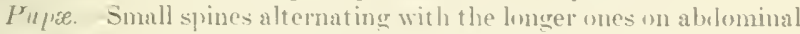
tergites and ninth epipleurites with a few bristles.

Larex - Abdominal spiracles ubseure; apical tuoth of the mandibles acute, the median emarginate, and the eve spots distinet. The lust is Pien sitchensis from the eonst of westem Wishington to sitka.

\section{Pissodes costatus Mannerheim}

This species is representer in the collection by a typeal specimen lalkeled with the name: "Pien: Iloquiam, Wish.; A. D. Hopkins, colleetor: ?.2; Ilopk. L.s. 2361gr." The specimen was reared from among

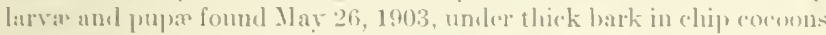
in outer woosl of stump of a tree of P'ica sitch nsis. folled in 1902.2.

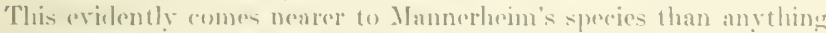
vet recomized, and the fact that it is fouml in the sitkal spruser is alditional ivilenere.

Jistenctive charaters. - This is the only representative of the lirst section (a.3) of sululivision 13 , and therefore is net closedy allied to any of the other species of the sululivixim. It is distinguished hy

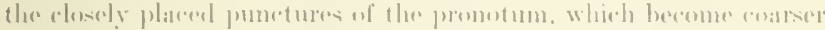
and nore distinctly separated toward the posterior lateral sortion,

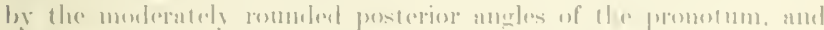

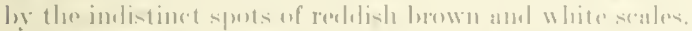

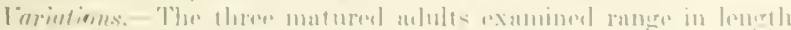

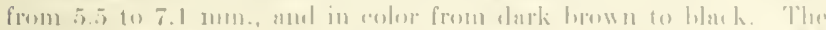

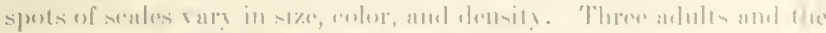

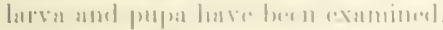

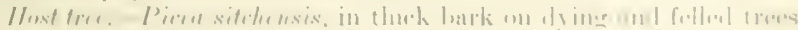
n11, - - 11111$)$ s.

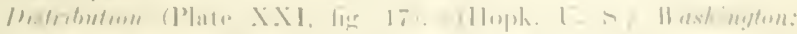

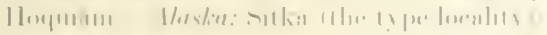


- SECTION aA

(Species Nos, 18 to 28.)

Adutts.-Basal angles of pronotum roumled; heak slender and moderately to very long.

Species 1s to 24 have the punctures of the pronotum distinetly separated and the punctures of the dytral strix small to coarse. In speries $1 \times$ to 21 the pronotum is not distinctly narrower than the elytra. Species is has a short, stout pronotum with the sides strongly rounded and constricted toward the anterior margin, the elytral interspaces with rather coarse rugosities. Sprecies 19 to 21 have a more elongate pronotum with romeled sides but not distinctly constricted toward the heat, and the elytral interspaces hare finc rugosities. In speeies 22 to 24 the pronotum is distinetly narrower than the elytra. Species 25 to 28 lave the punctures of the pronotum irregular in size and not distinetly separated and the strial punctures are very coarse and irregular. In speeies 25 and 26 the strial punctures are very irregular in size, the efytral spots moderately distinct, and the pronotum not distinetly narrower than the etytra. In species 27 and 28 the strial punctures are moterately irregular, the elytral spots are evident but small, ant the pronotum is distinetly narrower than the elytra.

Sexts.-In species 18 the apical margin of the serenth ablominal sternite of the mates is sinuate but without median process, while in species 20 there is a distinet median process, and in species 25 to $2 x$ the apex is uniformly rounded as in the females.

Pupa.-The fourth and filth ablominal tergites have two small spines hetwern the more prominent dorsal ones. In species 26 the rostrum is without a pair of spines botween the middle and apex, white in 27 they are present. Heal without distinet eye spots (so far as obserered).

Larea. In species is the ablominat spiracles are molerately distince, the apreat tooth of the mandibles obtuse, and the median tooth triangular. In speries 20 the apicat tooth is neute, and the melian tortlo is emarginate. In species 26 to $2 \mathrm{~s}$ the abelominal spirates are olsenre. In spereses 2 fi the apieal tooth is ante and the

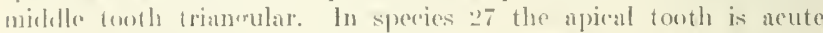
and the median one emarginute, while in speries 2 sthe apienl tooth is abtuse and the median one ematrinate.

Ilosts. Speries is, 19, 20, Picu: speries 21, l'inus: spectes 2.2,

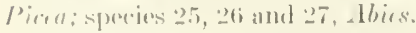

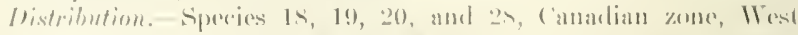

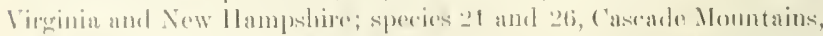

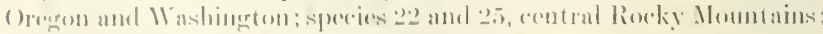

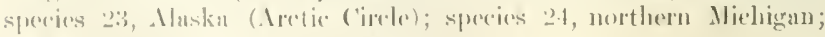

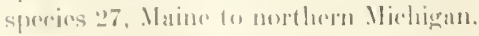


SUBSEctIOX b5.

(Species Nos. 18 to 24.)

18. Pissodes fiskei n. sp.

Plate I11, fig. Is: Plate XII.

The type specimen is labeled "Type Vo. 7.35, L.S.S.M.:" name: "type of srawing; Picen; Franconia, N. II., Oet. 16, '07: II. F. Fiske, collector; \& 1: IJopk. [". S. 33309." It wis reared with wher specimms from a section of a small spruce tree seorched by fire, collected October 16, 1907 .

bistinctive characters. "This is a very distimet speries, and may be known from its noarest ally, $P$. nigrap, by the strongly clevated third and fifth elytral interspares, and the larger yellow postrior spot of densedy placed scales, with no trace of an anterior spot. It is at once distinguisherl from $P$. similis, which may he associated with both speries in the lark of the sume tree, by it: large size, short pronotum. and loner loeak.

litriations. - There is not murle variation in size, the lengrth ranging from 4.2 to 5.2 mm., nor in other rharacters. Eight specimens of adults ancl work were examineil.

Ifost tros. - Picra rubens und Pica mariona, in thick bark on loges and trunks of small standing trees.

Jistribution (Plate XXI, fig. 1S).-(Hopk. I'. S.) Vow Ilempshirr: Rive.

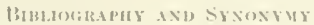

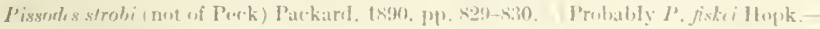
I II II.

19. Pissodes nigra 11 . N1

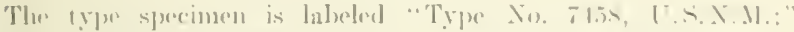

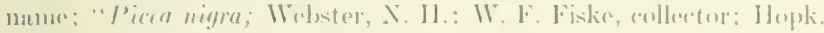

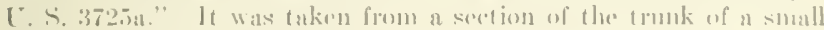

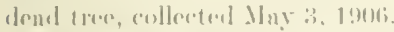

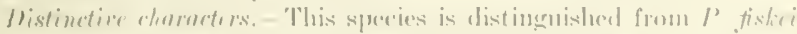

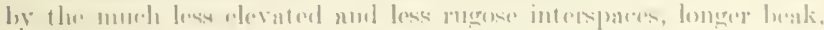

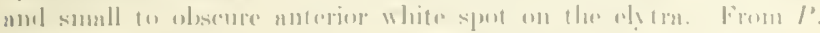

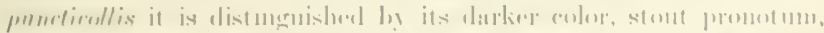

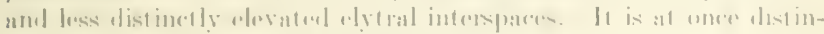

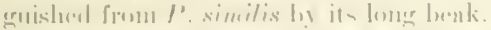

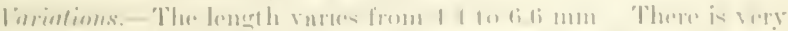

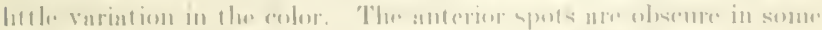

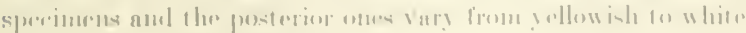

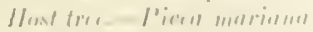

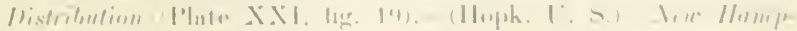
shime: IIrastere. 
20. Pissodes puncticollis n. sp.

(I'late 15, fig. 20.)

The trpe is labeled "Type No. 7437, T.S.N.M.;" name; "type of drawing; Picta; Randolph Co., IV. Va.; A. D. Topkins, collector; \& 1; Jlopk. W. Ia. 70." It was taken from the dead bark of a spruce log collecturl August 25, 1890.

Distinctive dharacters.-Closely allied to $P$. murrayand, but distinguished by its light reddish-brown color, irregular and less dense pronotal pumetures, and larger size, with the alternating interspaces less distinctly elerated, an anterior spot present, and the posterior spot listinct.

Tariations.-The length varies from 4.2 to $6.1 \mathrm{~mm}$.; there is very litte rariation in the color. The anterior white spot, which is small ard situated on the fourth interspace, is obseure in two specimens and situated on the fifth stria in the others. Four adults and 1 larra were examined.

IIost tree.-Picea rubens, in dying bark on felled and standing tree's.

Distribution (Plate XXI, fig. 20).-(Ilopk. W. Va.) West Virginia: (heat Bridge, Randolph ('ounty, Bayarl, Tueker County.

\section{Pissodes murrayanæ $\mathrm{n}, \mathrm{sp}$.}

The type specimen is laboled "Type No. 7436, L.S.N.M.;" nanne; "Pinns murrayana; Wallowa, Oreg.; A. D. Topkins, Apr. 10, '07, lyed; Hopk. U. S. 6560a." It was reared from the section of a suall tree receivel from correspoudent. H. K. O'Brien, february 14, $190 \%$.

Distinctive characters.-The single imperfect specimen representing this species is alosely allied to $P$. puncticollis, from the type of which it is distinguished foy its dark brown aolos, very small posterior spot, alsoner of an anterios spot, regular promotal pumetures, and hroad third wytral interspare. It is probable that now specimens will show a wider ranere of ratiation fiom those of $P$. puncticollis.

Ilest tree. P'inus mermayum, in thin bark.

llistribution (Plate XXI, lieg. 21).-(llopk. [T. S.) (loggon: Walloma.

\section{Pissodes coloradensis $\mathrm{I}$. s. .}

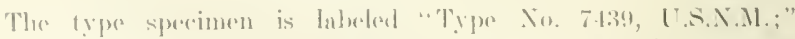

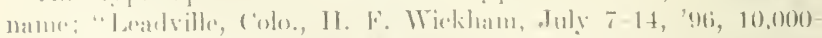

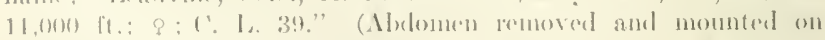

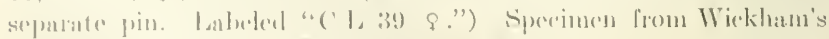
rolleretion in the I niterl sintes National Musenm.

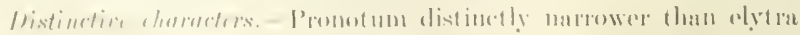

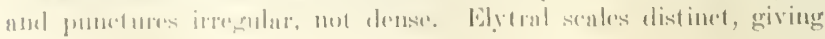


the surface a grarish appearance. Posterior spot promiuent, this readily distinguishing it from its nearest allies. $P$. alascensis and $P$. rotundatus.

Tariations. -Length 7.4 to $9.4 \mathrm{~mm}$. The color langes from dark brown to black. The color and densits of the scales rary as usual, as do also the elevation and rugosities of the alternating interspaces. strial punctures, etc. Twenty-seven specimens of arlults were eximined.

Host trees. - Picea canadensis in the Black IJills of Sumth Dakotil. It will evilently be found also in Piera fugrlmanui.

Distribution. (Plate XXI, fig. 22),-Black Hills of south Dakota: centrul Colorado.

23. Pissodes alascensis $n-1$.

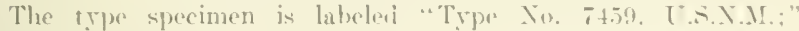
name: "Koysukuk R., Alas., L. . 67-6i9, I.g. 151, summer 1901: IV. J. Perters. andlector."

Mistindier charncters. - The darker colos and closely placed ret separated proustal punctures, sparse elytral scales, and small posterior spot an the elytra serve to listinguish the single specinen of this species from $\dot{P}$. coloradensis, and the distinetly elevated and rugrese alytral punctures distinguish it from $l$ '. rotundatus. One sperimen only was examinesl.

IJwet trer.-Probilbly Picra.

llistribution (Plate XXI, lig. 2:3).-IIopk. C. . . I/aska: Koyukuk River, Arrtie (ircle.

24. Pissodes rotundatus I.f. I'inte.

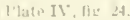

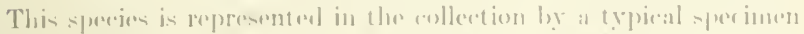

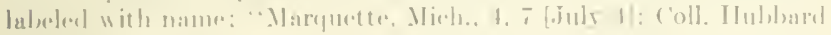
d.

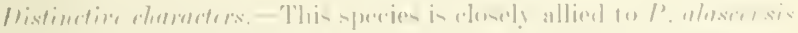

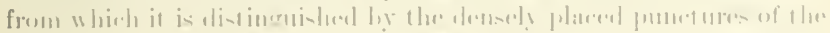

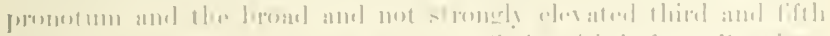

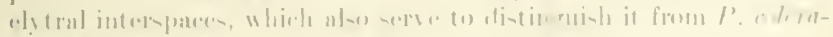
densis.

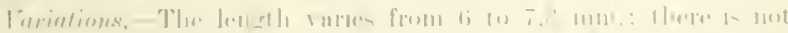

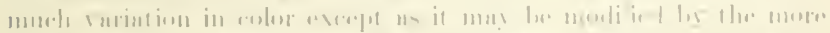

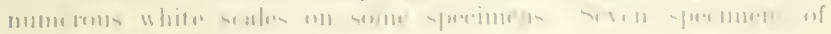

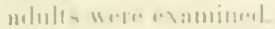

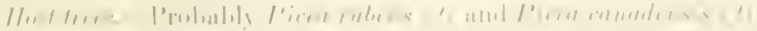

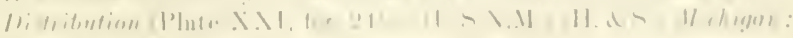

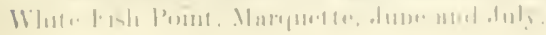




\title{
BIBLIOGRAPHY.
}

Pissodes rotundalus Le conte, 1876, pp. 142, 143-144. Hopkins, 1906, pp. 254, 256, fig. 69.

\author{
Subsection 66. \\ Species Nos. 25 to 28 .)
}

25. Pissodes burkei $n$. ep.

(Plate IV, fig. 25.)

The type specimen is labeled "Type No. 74t0 U.S.X.M.;" name; "above Ouray, Colo., 9,000-10,000 ft., Mineral Point Trail, VII, 1597, H. F. Wickham; $q$ t." From Wickham's collection. Adritional specimens collectod and host tree determined by II. E. Burke.

Distinctive characters. - This species is quite distinct from $P$. rotundatus but is more closely allied to $P^{\prime}$. prperi, from which it is distinguished by its decidedly grayjsh appearance and the distinct posterior spot of the elytra.

Tariations.-The length raries from 6 to $7.7 \mathrm{~mm}$, lut there is comparatively little variation in the color, except in rubbed specimens which are larker. Thirty-two specimens were examincl, inchuding all stages and work.

Inst tree.- Ibies lasiocarpa, in thick hark on liring and dying trees.

Distribution (Plate XXII, fig. 25).-(IIopk. U. S.) Tta7: Kíamas (Burke, collector). (U'.S. .....) (II, \& S.) [tah: Alta and Park City, June (under P. costatus). Coloralo: (Juray (Wickham).

\section{Pissodes piperi n. sp.}

(Plate 1V, fig. 2f; Plate V, fig. A; Plate XVIII; text fig. S, A.)

The type sperimen is labeled "Typo No. 7411, U.S.X.M.;" name; "type of Jrawing; Mt. Ranier, Mash.; collector, C. V. Piper; \& 1." dilitional specimens were collected and host trees determined by Jhesses. 11. E. Burlie and I, 1. Webb.

Distinctive charecters. - This species is at once distinguished from P. burkei by its larese size, dark color, sparsely placed elytral scales, small posterior spot, and very coarse and deep punctures of elytral strial.

leriations. The Iength varies from 7.4 to $10 \mathrm{~mm}$. and the posteriore spots of the clytra vary from obseure to distinct. Five adults amd l:s specimens examined, including all stuces and work.

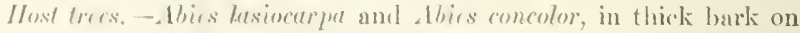
trumks of liviner (!) and dying treses.

Jistribution (Pate XXII, fig. 2(i).-(Hopk. U. S.) Mashington:

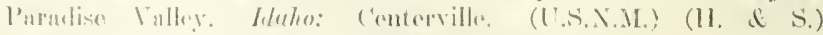

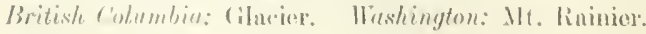


27. Pissodes dubius Razilatl.

(Plate 15, 6g. 27.)

This species is represented in the rollection hy a trpical specimen labeled with the name; "MIarquette, Mich., 27.6 [.hune 27]; ('oll. Hubbarul \& Seliwarz; $\$ 1 . "$

Distinctire characters. - This species is rosoly allied to $P$. fraseri, from which it is distiaguished by its medium size, moderately long beak, and the regular convex promotum without broml inpressions.

Tariations. - The length varies from 4. 4 to $5.7 \mathrm{~mm}$. and as usual there is considerable variation in color clue to rubbed and immature specimens. Forty-one sjecimens were examined, inclucling all stages and work.

Host tree.-Abirs balsamea, in thick livine and dying bark on trunks of liviner and dying tress and stam jes of storm-turolien trees.

Distribution (Plat* XXI, fig. 27).-(Ilopk. L. S.) Maine: Lake Parmachene, Beaver Pond (Boil Mommain). Now Itampshire: Dartmouth (ollege, Fubyan, IVaterville. Gichigan: Grand Island.

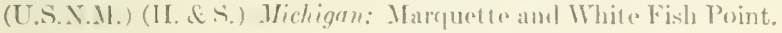

BHBLU:RAIII:

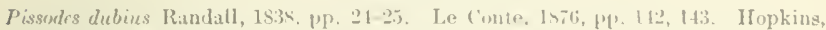

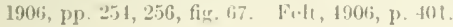

\section{Pissodes fraseri n. s1.}

(Phate 11, 0iz. 24: text fi: 9.)

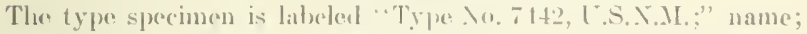

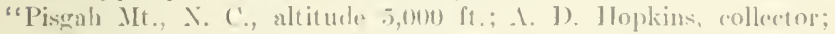

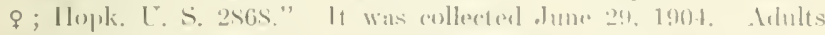

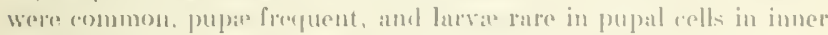

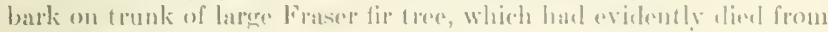
rout diverase.

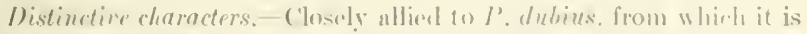

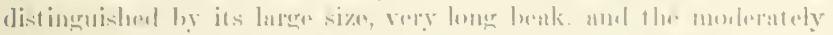

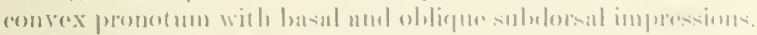

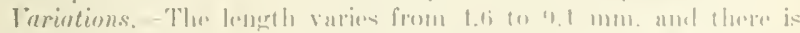

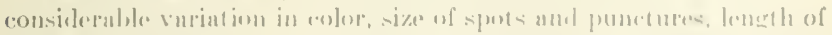

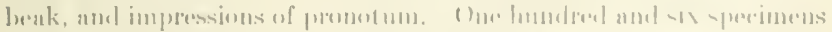

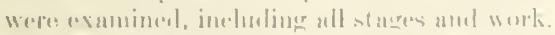

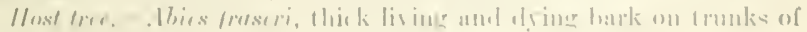
livine numl ilsingeteres.

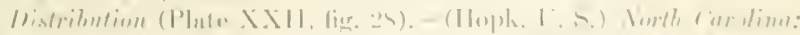

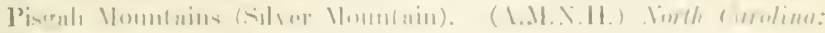

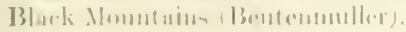




\section{DIVISION II.}

(Species Nos, 29 and 30.)

Adults. - Third and fifth elytral interspaces not broader or more elevated than second and fourth. Beak shorter than prothorax, slemder. Pronotum broad, with sides behind the middle nearly parallel with the basal angles, rectangular. Punctures of elytral strice moderately coarse, regular.

Sexes.- Posterion tibix of the males fringed with long hairs. Apical margin of the seventh abdominal stemite of the males with a trumcate process arising from a leep emarcination.

Pupde.-Fourth and fifth ablominal tergites with two small spines between the more prominent dorsal ones. Rostrum with a pair of small spines between the apex and the micllle.

Larva.- Not known.

Ilost.-Pinus.

Distribution.- Species 29, New Hampshire to northern Pennsylrania, Westward into Mimmesota; species 30, British Columbia.

29. Pissodes affinis Randall.

(Plate IV, fig. 29; Plate F'l, fig. 29.1

This species is represented in the colleetion by a typical specimen labeled with name; "Marquette, Mich., 26.6 [Jume 26]; Coll. IIubbard \& Sehwarz; $\$$.?."

Distinctive charactor. - This species is at once distinguished from all of the preceding ones of the genus by the equal width of the alytral interspaces, the thind and tilth of which are not elevated; and from its nearest ally (I'. ('umiri) by the long posterior spot on the elyta and by the moderately coarse strial punctures.

Fariations.- The lenerth varies from 5.5 to $x$ mm., and while the sculpture and color are quito comstant there is eonsiderable variation in the spots of scales, hoth in color and density. Twenty-nine adult sperimens were examined.

llost tro. Jinns strobus, in thick bark on stump. (As determiner by W. F. Fislie.)

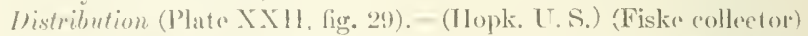
lem Ilamplime: Welster or l'enacook. (U.S.N.M.) Minnesota.

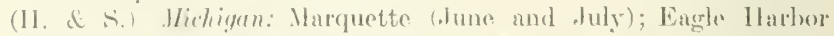

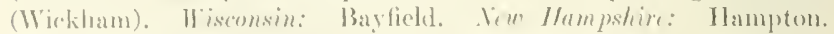

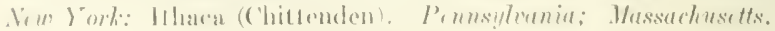

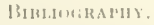

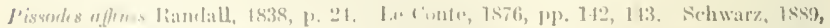

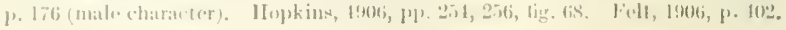


30. Pissodes curriei u. sp.

(Plate VI. fig. 30.)

The type specimen is labeled "Type .No. 7t43, L'S.X.M.;" name; "Kaslo, P. ("., 2.7 [July 2, 1903]; R. P. (urrie, collector; o 1."

listinctive charactrs. This species is distinguished from $I$ '. affnis by the very sparsely placed scales, the obscure anterior spots, the small posterior spot on the elytra, and the coarse and deep strial pumetures.

Tiriations.-The length raries from 5.6 to $7.7 \mathrm{~mm}$. There is very litule variation in sculpture, spots of sciles, etc. Seven atult specimens were examined.

llost tree. lonkmown, probahly Pinus.

Distribution (Plate X.II, fig. 30).-(L.S.X.M.) British Columbia: Kaslo.

\section{LIST OF DESCRIBED SPECIES OF PISSODES, ${ }^{a}$}

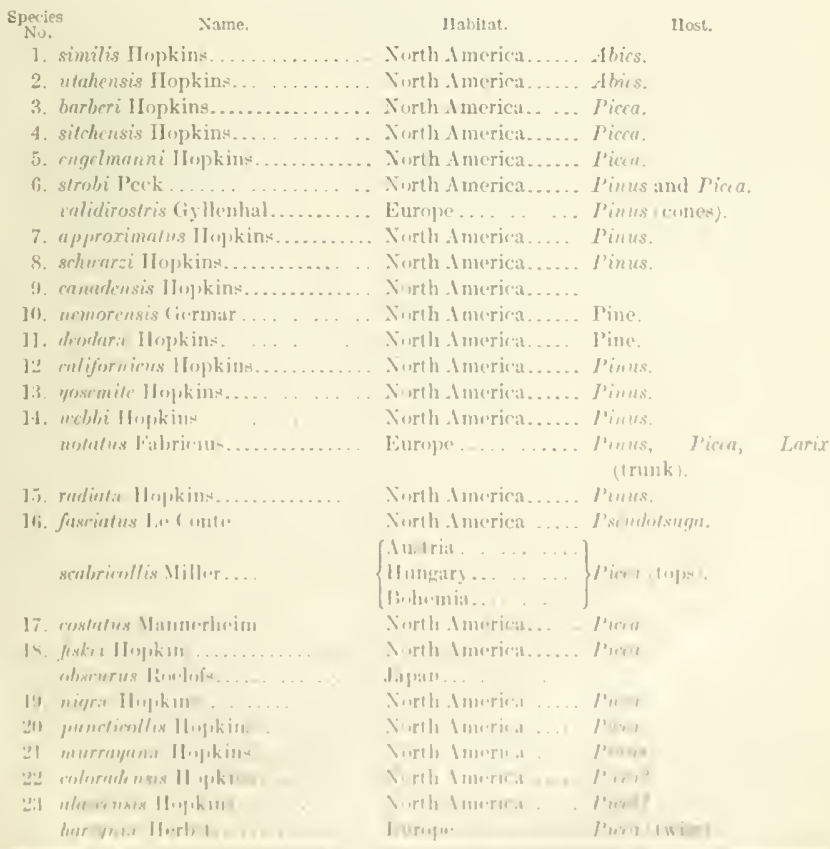

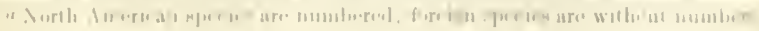




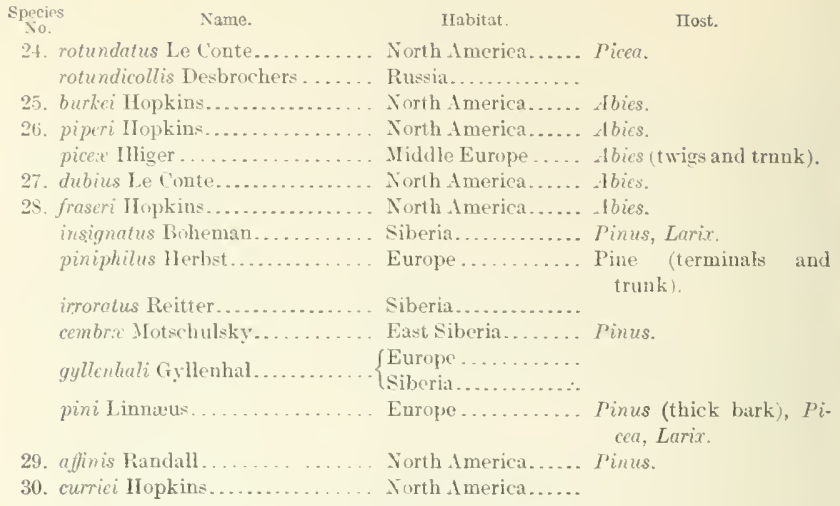

\section{BIBLIOGRAPHY.}

1758. Linseus, C.- Systema naturæ, tenth edition, p. 379.

1775. DE REER, C.-Memoires pour servir a l'histoire des insectes, vol. 5, p. 231.

1787. Fabricues, J. C.-Mantisa insectorum, vol. I, p. 103.

1795. HERust, J. F. II. Natursystem aller bekannten in-unl-ausländischen Insek1en-Kifer, sechster Theil, p. 294, taf. 82, fig. 11.

1797. Hernst, J. F. W. - Natursystem aller bekannten in-und-auslindischen Insekten-hafer, siebenter Theil, p. 21.

[798. Sсиламк, F, von P.-Fauna Boica, vol. 1, p, 480.

1S0I. PANZER, (i. W. F. Fauna insectorum germanicie initia oder Ileutstllands insecten gesanmelt von hrsg. von. D. Georg Wolfigang Franz Panzer.

1801. Fiвныст, J. C.-Sysima cleutheratorum, vol. 2, p. $19 \mathrm{~s}$.

1507. Ih.IGik, ('.-Ifagizin fur Insektenkunde, vol. 6, p. 309.

1807. Dhvisk, A. (i.-Entomolngie, ou histoire naturelle des insectes, vol. 5, ?. 116, No. 83, pl. 16, figs. $12, b, c$, pl. 4, fig. 12.

1413. fizlexirat, L. Iniswta suecica descripta, vol. 3, p. $6 \mathrm{~s}$

1:17. PECK, II: 1). On the insects which destroy the young branches of the prear-tree, and the leading shont of the Weymouth-pine. CMfass. Agr. Journ., vol. 4 , No. 3, p. 209, pl. 2.

1817. Círman, l. F, Magazin der Entomologie, vol. 2, p. 310, Xin. 30.

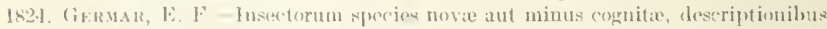
illu<t rata, wal. 1, pl. 3)(i-3)!

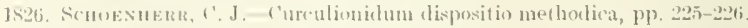

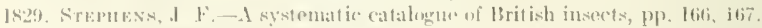

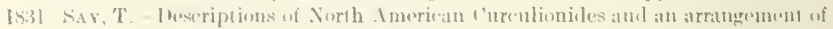

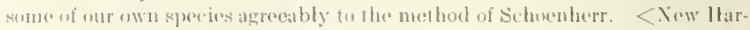
um,ty, Incliana, p. Jl.

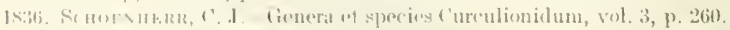

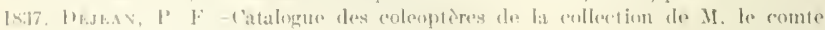

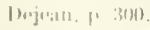

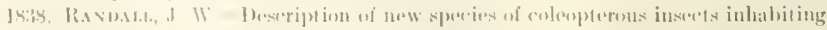

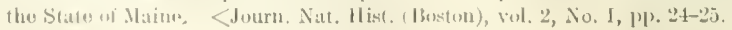


1839. Ratzeburg, J. T. C.-Die Forst-Inzekten, whl. 1, pp. 142-14i, tai. 5, figs. 1, 2. 3. $-\frac{1}{2}$.

1811. Harre, T. W.-A report on the insects of Masschuset ts injurisus to ingetarion, pp. 1 (j3-65.

1843. (Bohemax, C. H.)-In Schnenhert, Gencra et speries ('urculionidum, vol. 7. lp. $133-134$.

1852. Maxiermem, G. G. von. -Zweiter Nachtrag zur haper-Fama der mordimerikanischen Laender des russischen Reiches. <Bul. Suc. lmp. Nat. IImor. vol. 25,2, p. 351 (reprint, p. 171 ).

1856. Permis, Enocand, - llistnire des insectes du pin maritime. <Ann. Sux. Ent. Franc', vil. 1, pp. $423-131$.

1858. Fitcu, A. - Fourth report on the noxinus and other insects of the sitate of New York, pp. 732-736, in reporls combined.

1859. SAY, T. The omplete writings of Thomas Suy on the entomology of Worth Anrerica, mlited by John I. Le Conte, .I. D., rol. 1, p. 27.

15.59. Jallen, 1. Eine Excursion in das Tatra-Gehirge. KWien. Ent. Munatsschrifi, P. 364 .

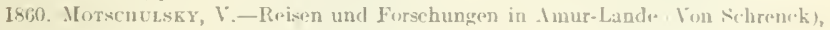
vol. 2.

1.6i3. Lacombatre, T. - IIistoire naturelle des insectes, vol, 6. 1. 461 .

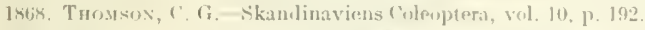

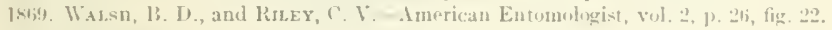

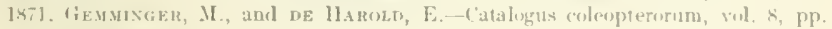
2.131 $213:=$

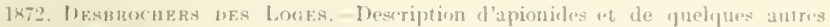

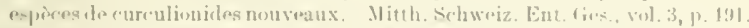

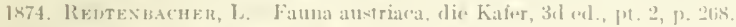

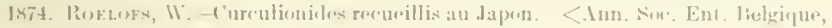
vol. 17. P. 121.

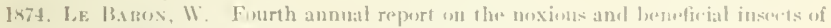
the. St:ate of Illineris, p. 139, tig. 63.

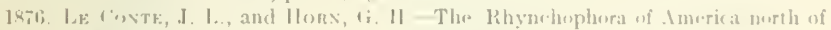

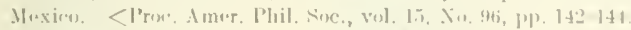

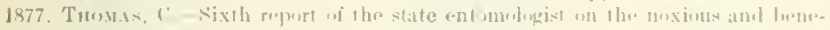

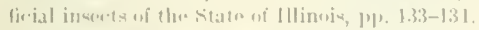

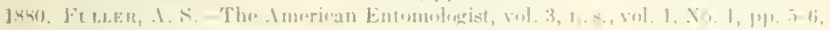
ligr :3.

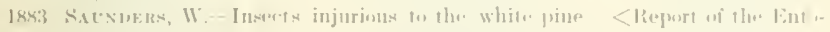

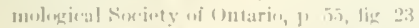

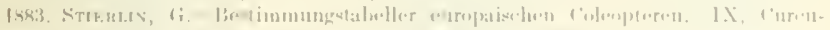

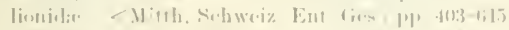

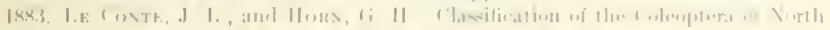

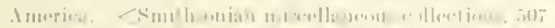

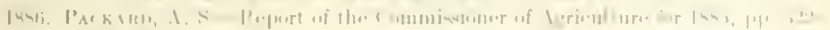
$32,11 \leqslant$

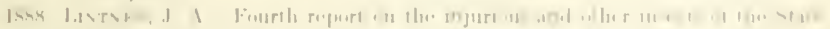
if Virs Yiork, 1' 21, lig 1;, ,

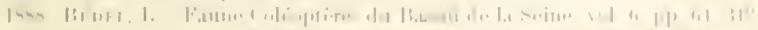

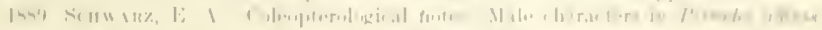

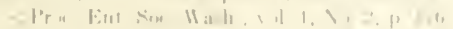

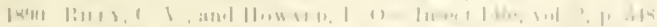

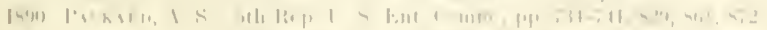

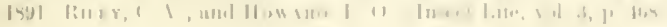


1593. Lintaer, J. A. - Ninth report on the injurious and other insects of the State of New York for the year 1892 , pp. 314-345, fig. 22

1893. Hopkixs, A. D.- Catalogue of the II est Virginia forest and shacle tree insects. <Bul, 32, II. Va. Agr. Exp. Sta., May, p. 205.

1895. REY, C.-L'exchange, Revue Linneenne, vol. 11, P. 2.

1899. Hopkins, A. D.-Bul. 56, IV. Ta. Agr. Exp. Sta., np. 259-260, 345, 429, 441.

1899. Reitter, EDu.-Beitrage zur eoleopteren-fauna des russischen Reiches und der angrenzenden Laender. <Deutsch. Ent. Zeit., p. 208.

1899. "hittendex, F. H.- "Insects Injurious to the White Pine," in BuI. 22, Div. Furestry, L. s. Dept. Agr., pp. 58-59, figs. 11, 12.

1899. Lugger, U.-Beetles injurious to fruit-producing plants. <Bul. 66, Minn. Agr. Exp. Sta., p. 275.

1902. Champlon, G. C.-Biologia Centrali-Americana, Curculionidæ (Cureulioninæ), vol. 4, pt. 4, p. 119.

1903. Gajglbatr, C. L.-Grundzuge eines neuen Systemes der Koleopteren. <Münchener koleopterologisehe Zeitschrift, vol. 1, pp. 299, 308-309. Systematische-koleopterolngische studien, pp. 271-319.

1903. Kоцве, H. J.-Zur systematik der Coleopteren. <Allg. Zeitsch. f. Ent., vol.8, pp. 137-145.

1905. Stiles, C. II:- The International Code of Zoological Nomenclature as applied to medicine. <Bul. 24, Hygienie Lab., September.

1905. Nüsstix, O.-Leitfaden der Forstinsektenkunde, PP. 122-131.

1906. IIopkixs, A. D.--Inseet enemies of forest reproduction. <Yearbook U. S. Dept. Agr. for 1905, pp. 249-256, figs. 61-69, July.

1906. FeLt, E. P. - Inseets affecting park and woodland trees. <N. Y. State Mus., mem. \&, vol. 2, pp. $397-101$.

1906. Hexden, Reitter, u. Weise.-Catalogus coleopterorum Europer, p. 657.

1907. Ilopkins, 1. 1).-The white-pine weevil. <Cir.90, Bur. Ent., U.S. Dept. Agr., p. 8 , figs. 6.

1909. IIopkixs, A. D.-Coutributions tomard a monograph of the scolyticl beetles. 1, The genus Dendroctonus. <Tech. Ser. 17, l't. I, Bur. Ent., U. S. Dept. Agr., 11'. 11, 16, 17, figs. $8,9$. 


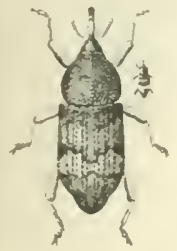

1

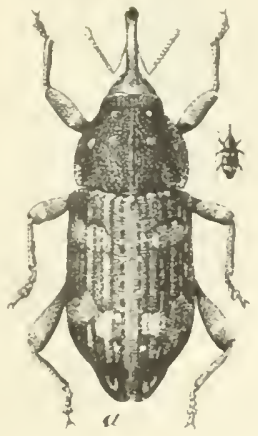

c

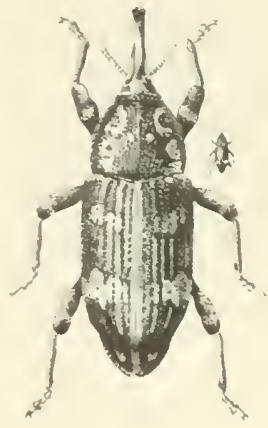

8

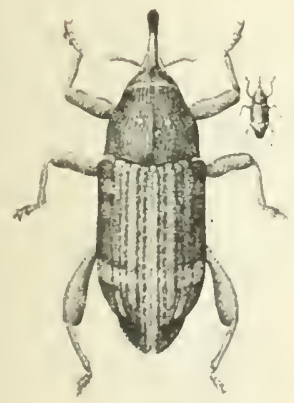

15

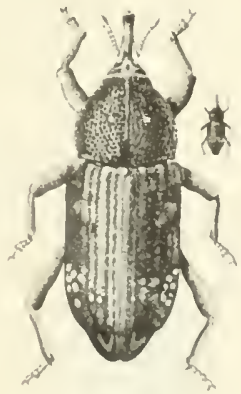

16

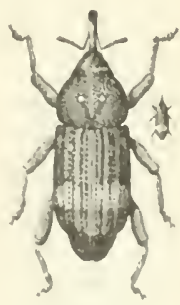

18

ADII i I P PUDES.

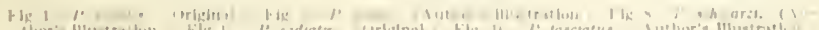

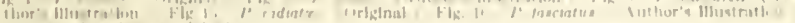

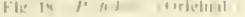



Tech. Seres zu Par. Bureau of Entomology, U. S. Dept. of A gricu twee

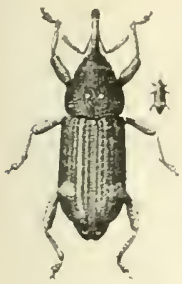

20
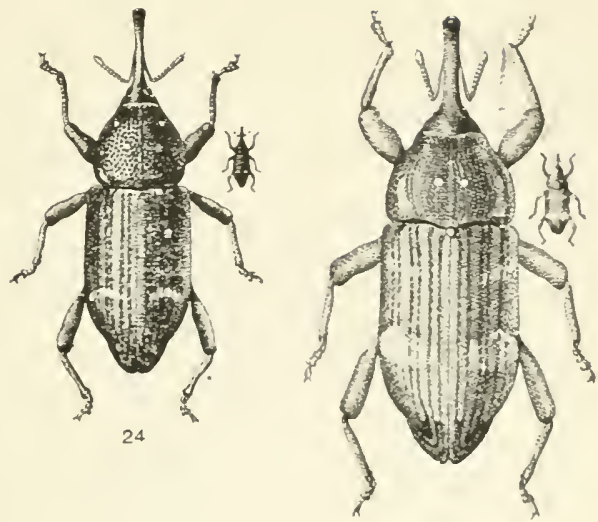

25

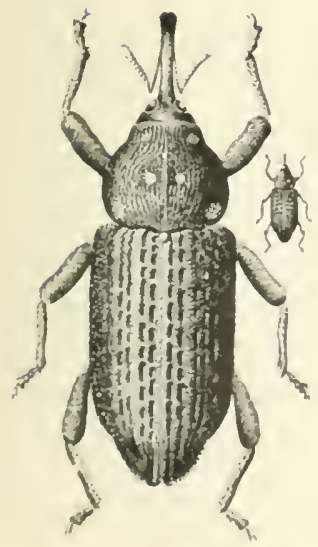

26

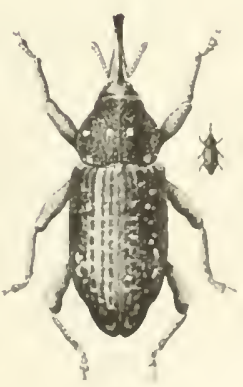

A UU TS F PIS JE

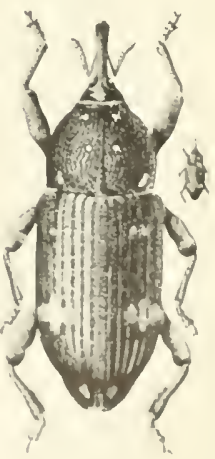

29

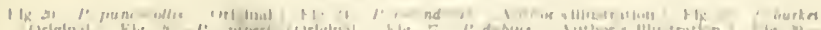

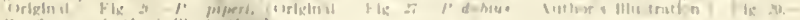

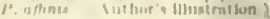




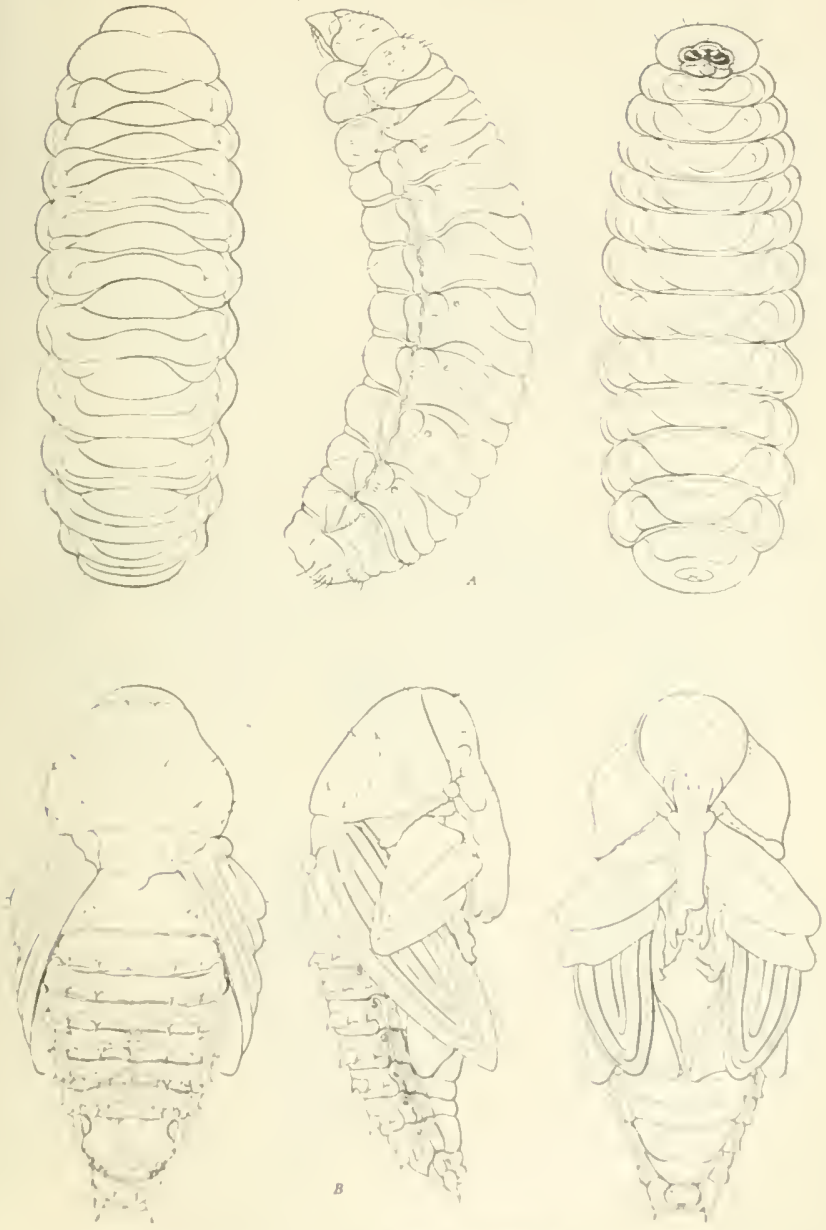

LAH, A AN, PII, \& P IF if 




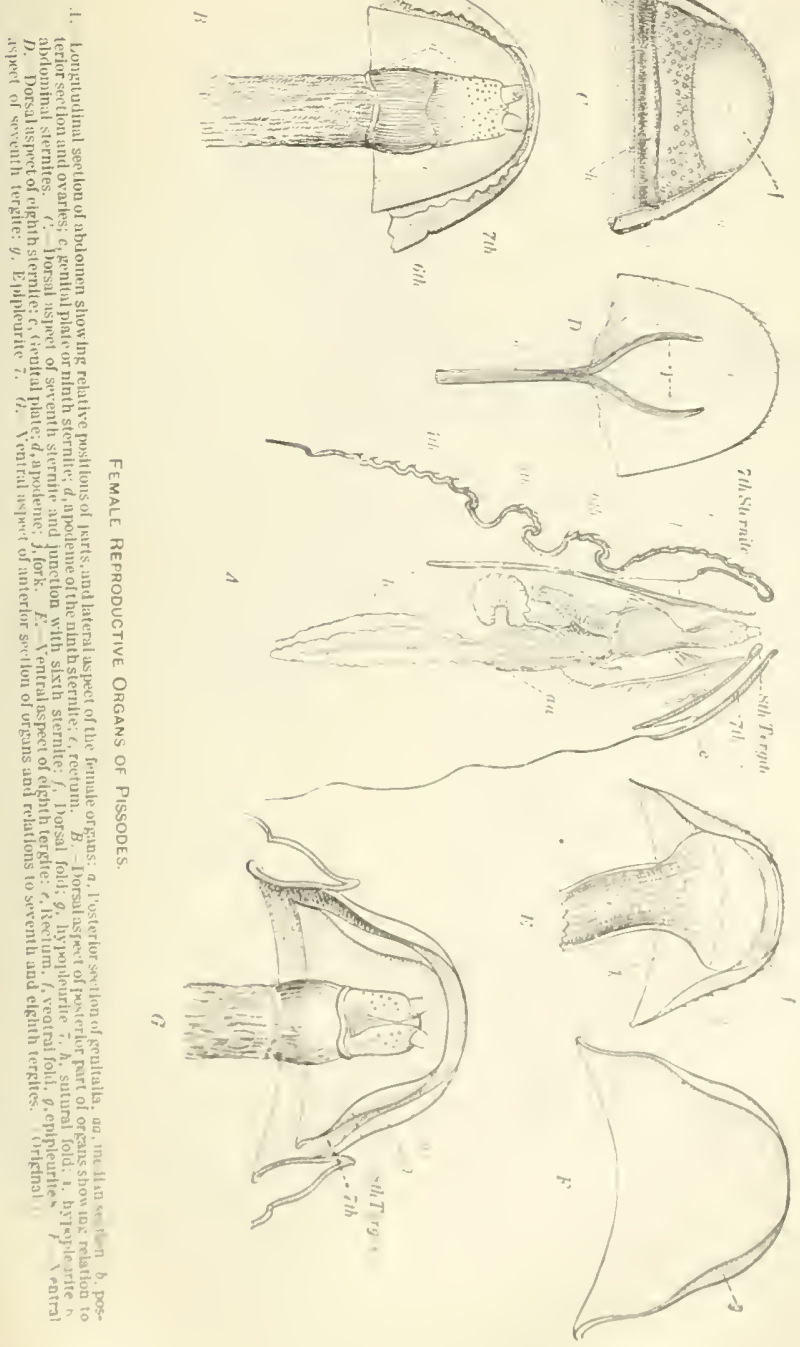






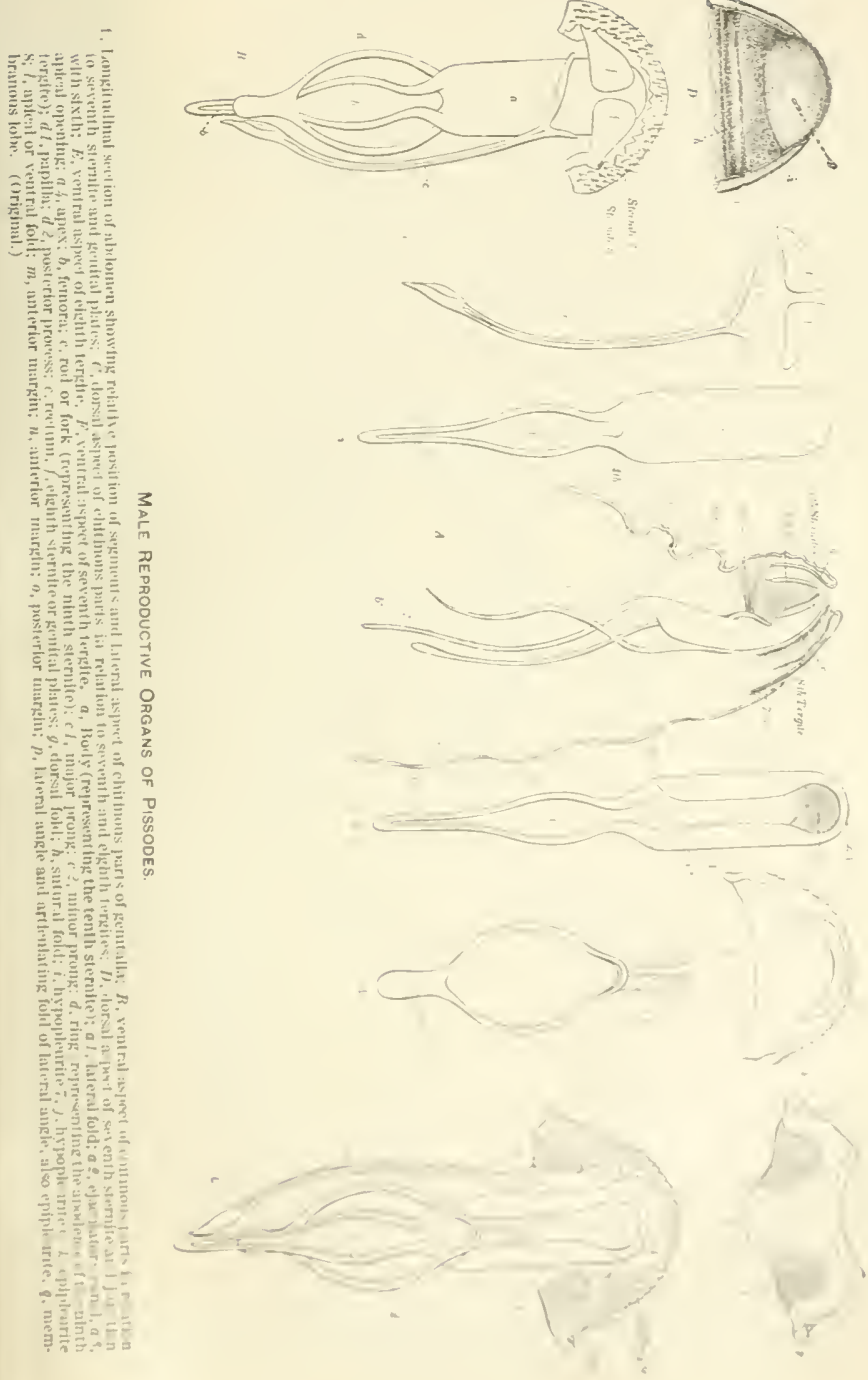



Tech. Serves 24 Part I, Bureau of Entomology. US Dept if agriculture

Plate $X$.
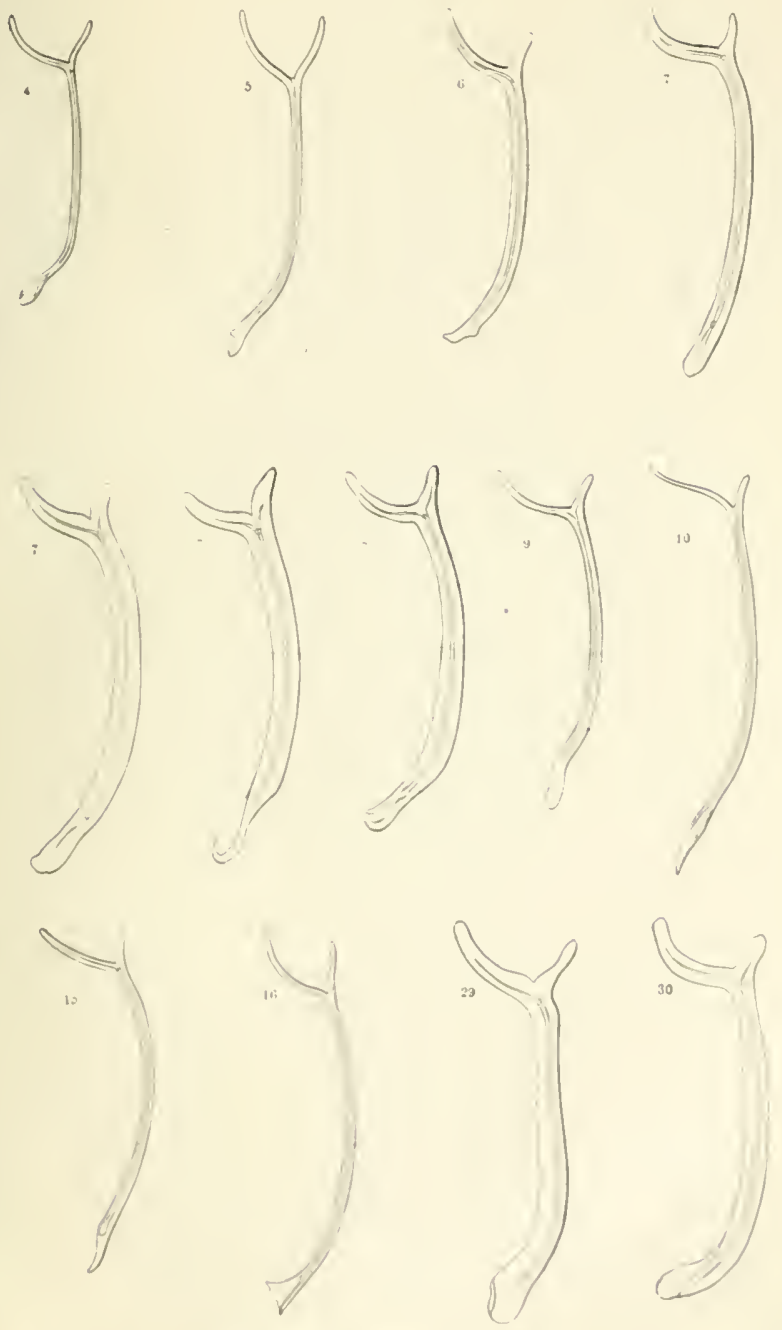

Forks of MALE Gin tabla of Pissudes

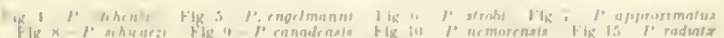

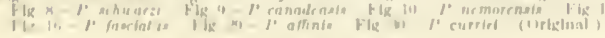





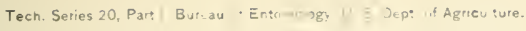

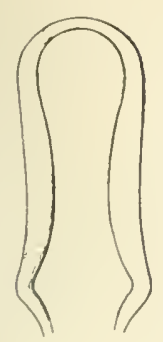

4

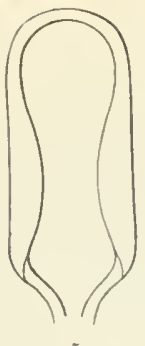

5

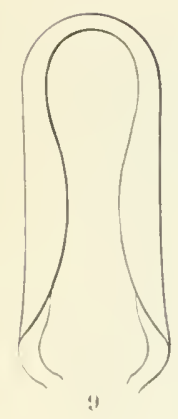

T

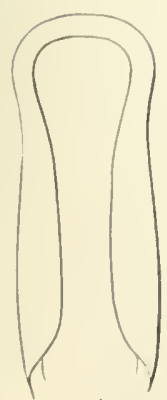

lii

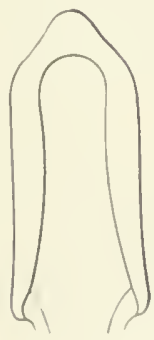

$\geq ! 1$
Plate XI.

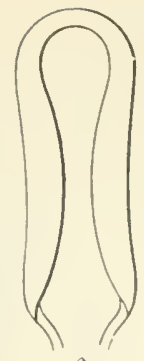

6

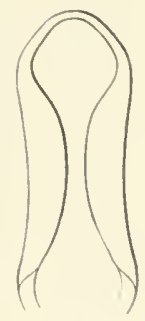

15

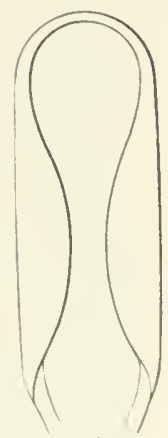

I1)

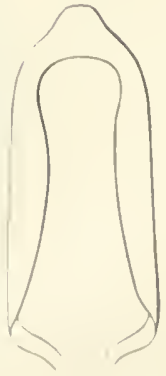

31

STEMS OF MALE GLNITALIA OF PISSODES

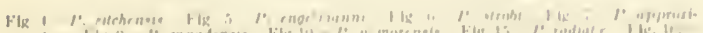

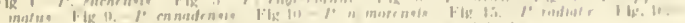

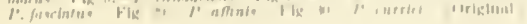





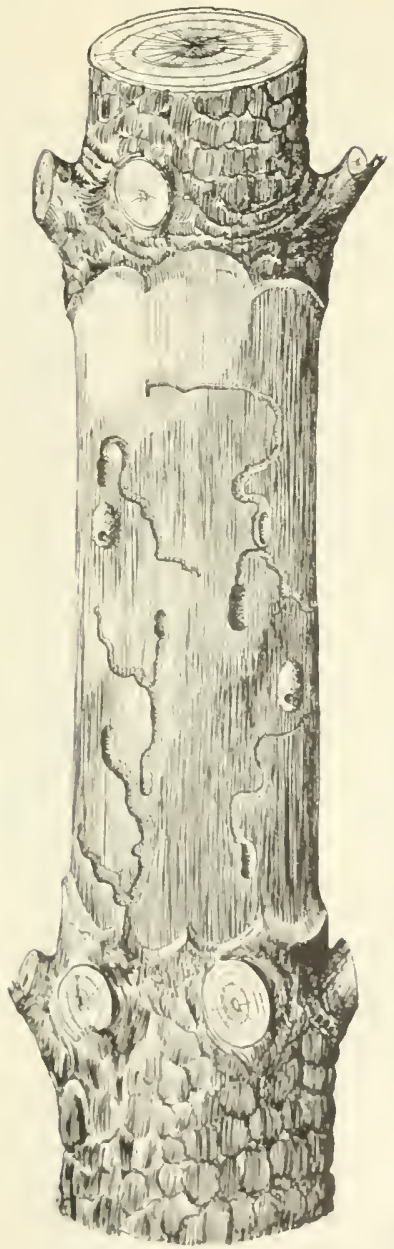



Tech Ser th, Part Bureau if Entomalogy L S. Deo: d'Ag: -. ture

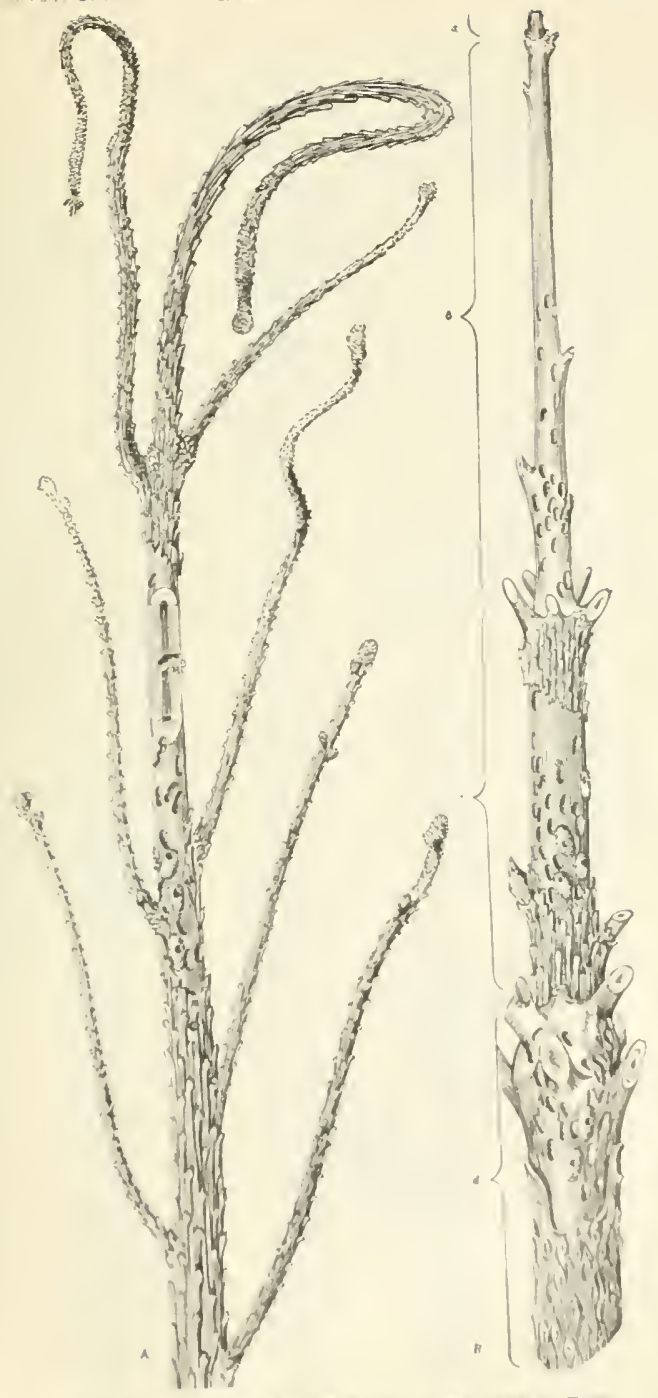

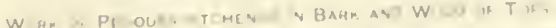



Tech. Sertes LU, Part. Bureau of Er:omology U S. Dept of Agriculture. PLATE XIV.

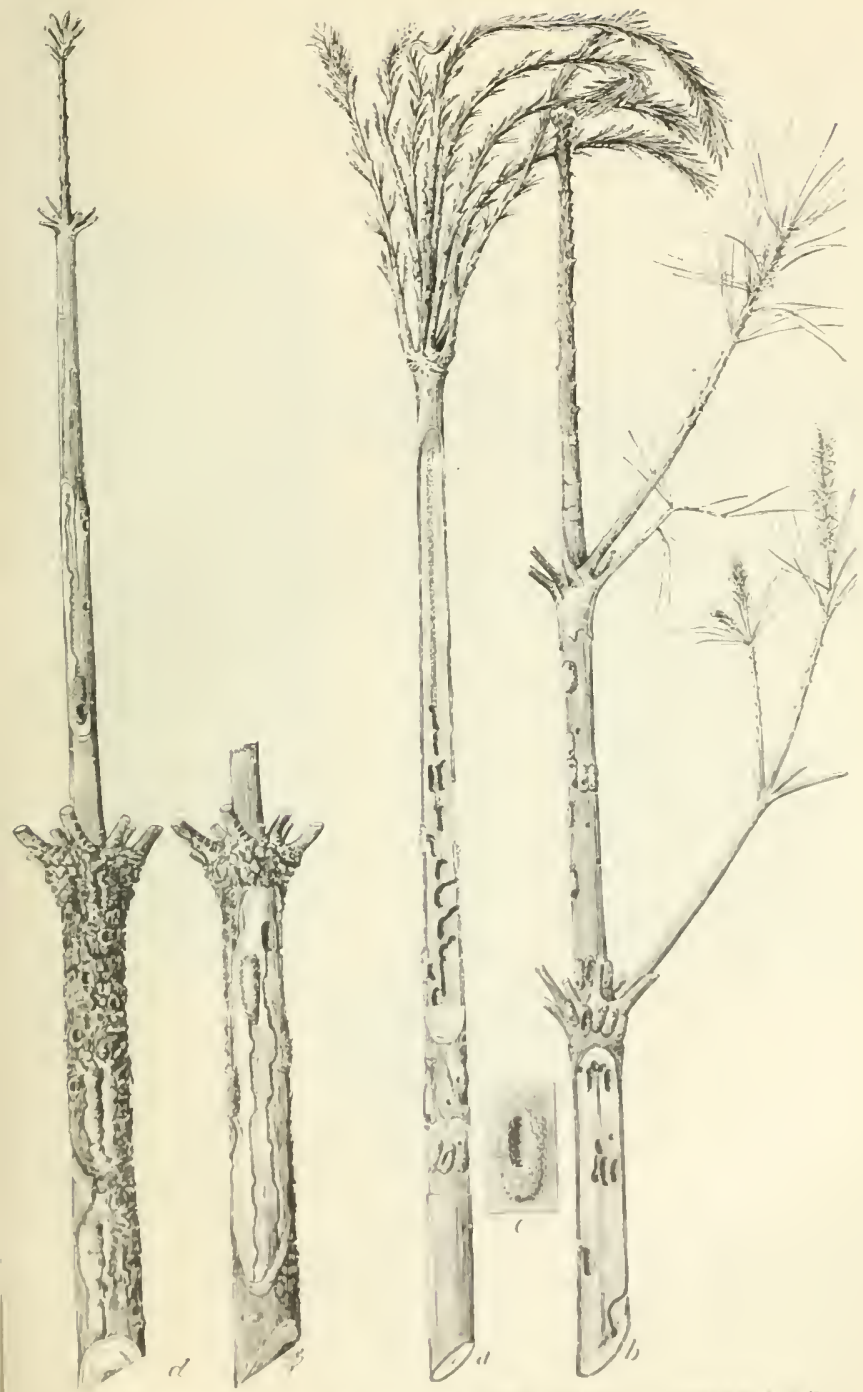





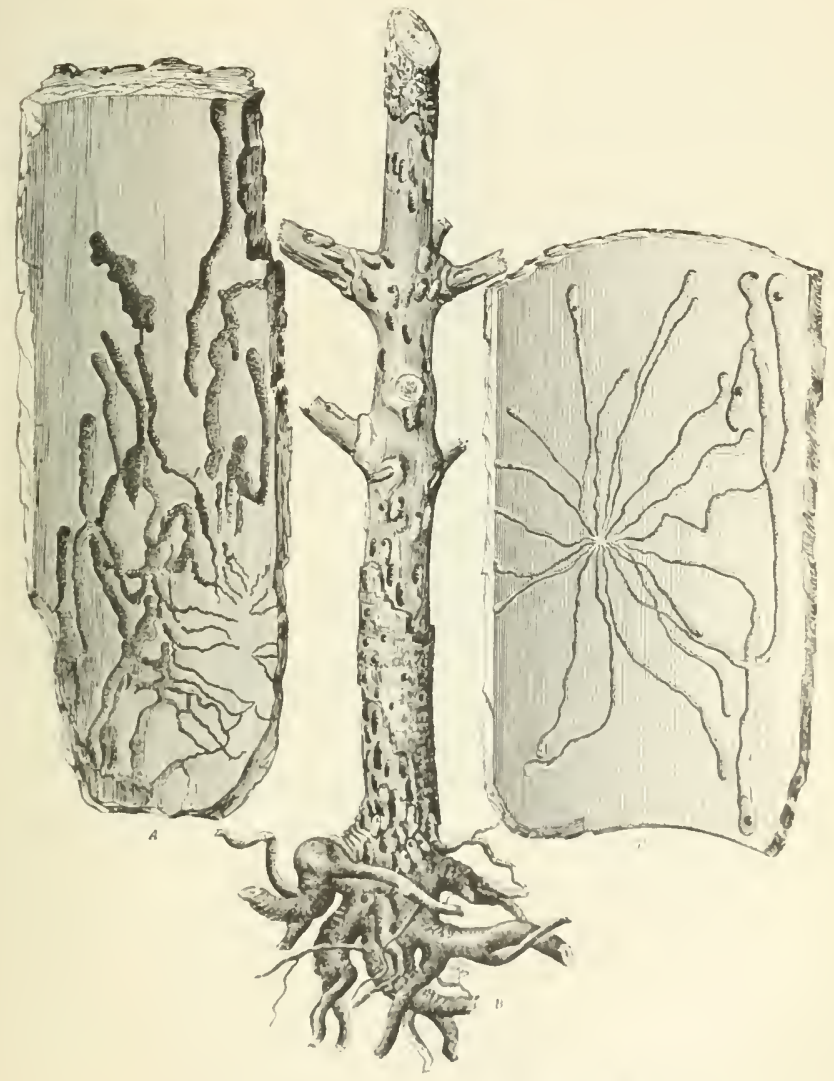

WoAR of PISSODES APPROXIMATUS AN. P NEM R NSI.

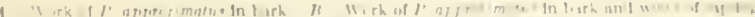





$$
11
$$




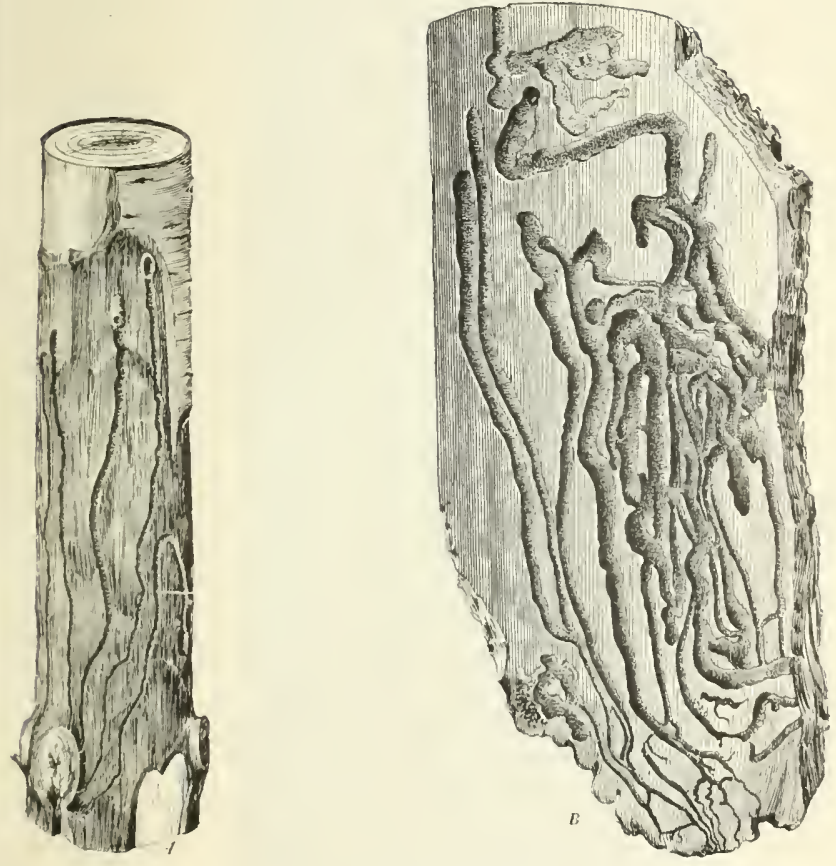

WORK OF PISSODES FASCIATUS.

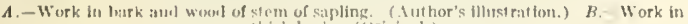





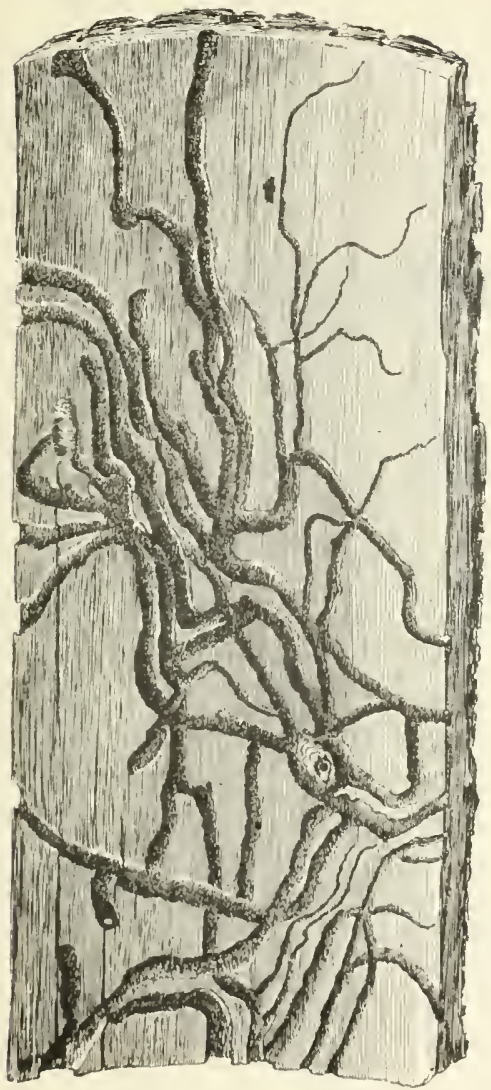

WORK OF PISSODES PIPERI IN BARK. (ORIGINAL.) 


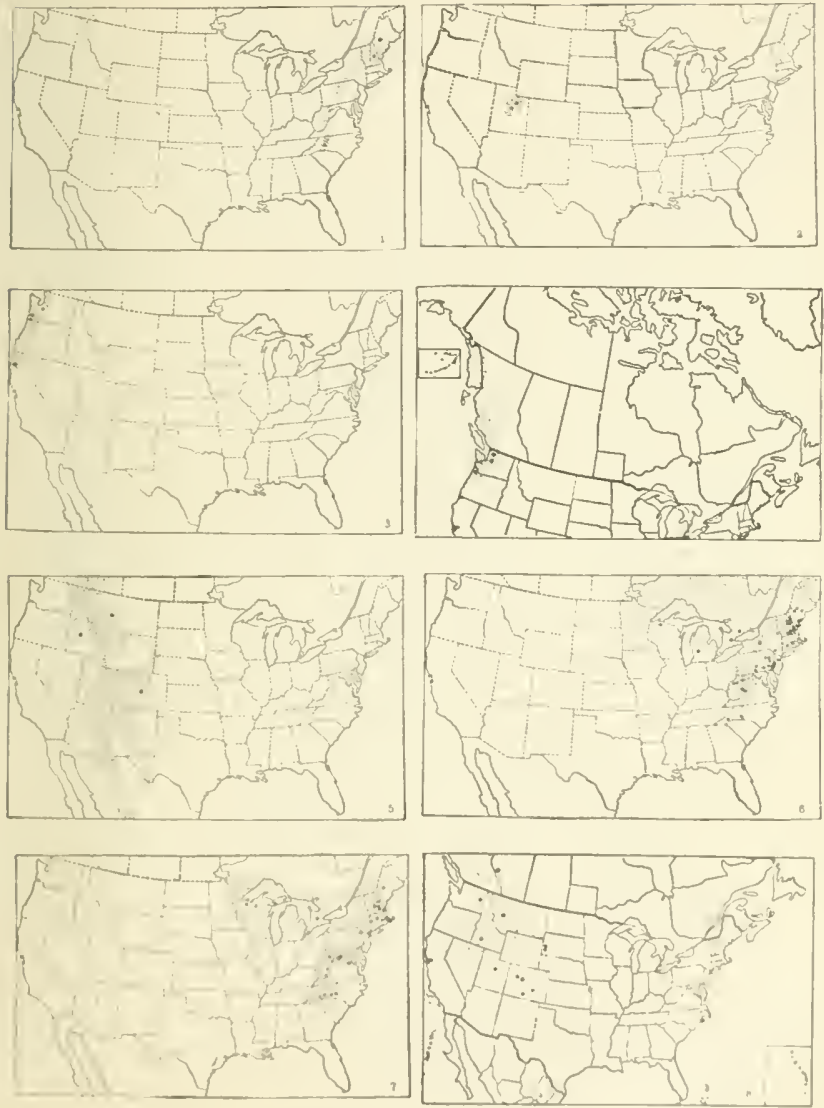

Distribution MAPS OF PISSODEs."

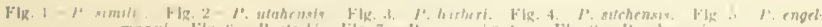

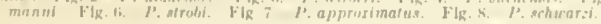




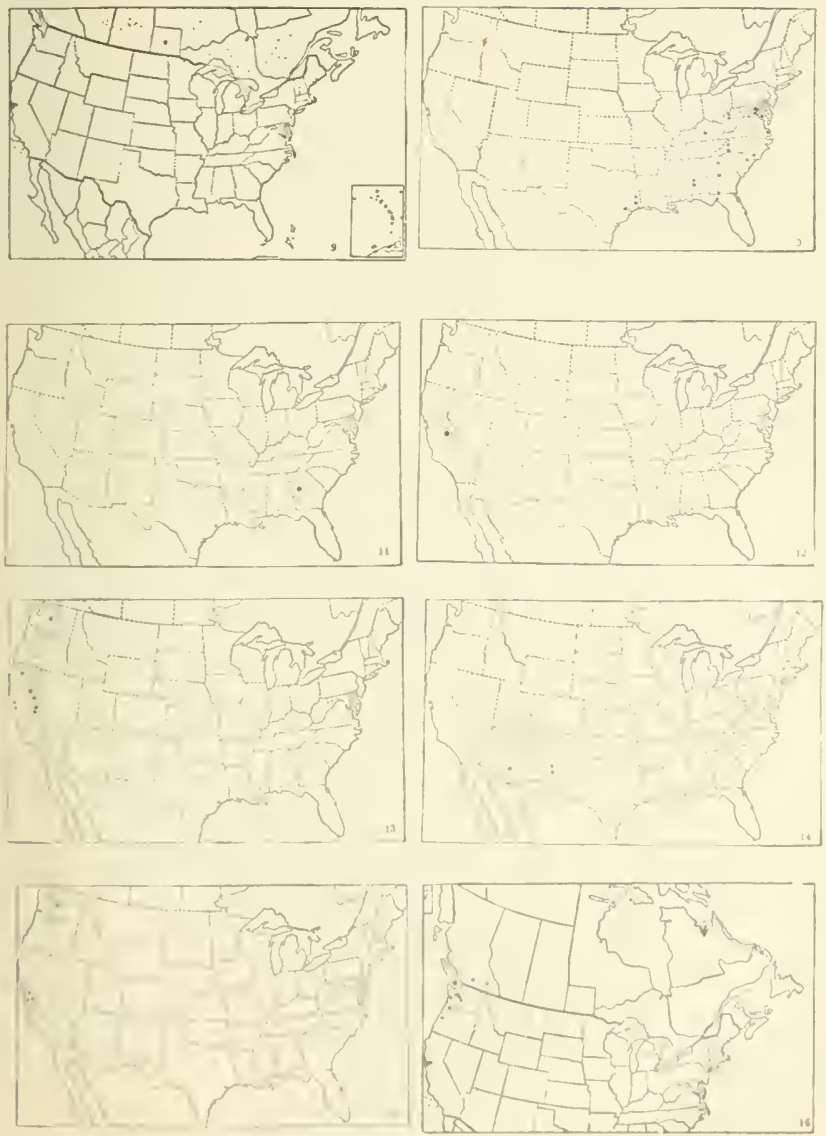

Distrigution MAPS OF PISSODES.

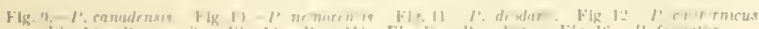

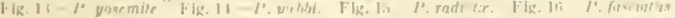




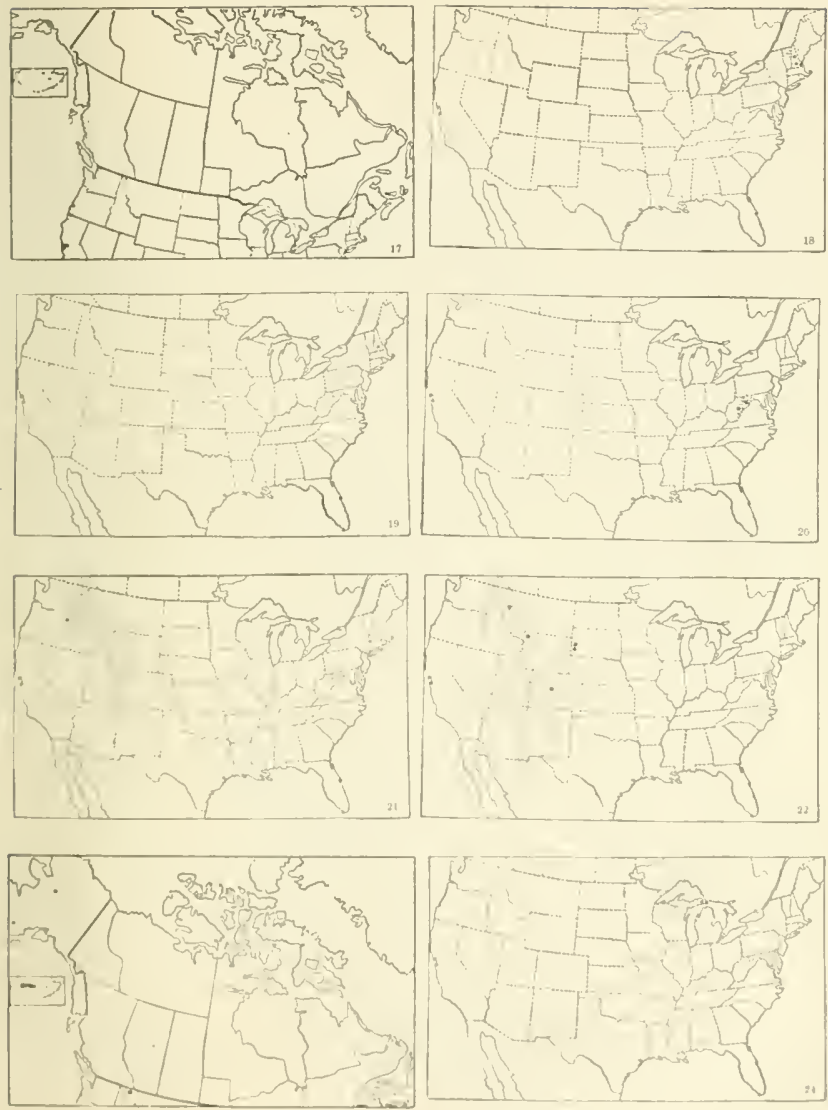

Distribution MAPS OF PISSODEs.

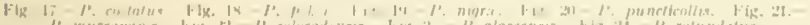

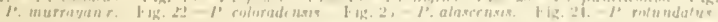



Tech. Series 20, Pant 1, Bureau of Entomology, U. S. Dept. of Agriculture.

PLATE XXII.
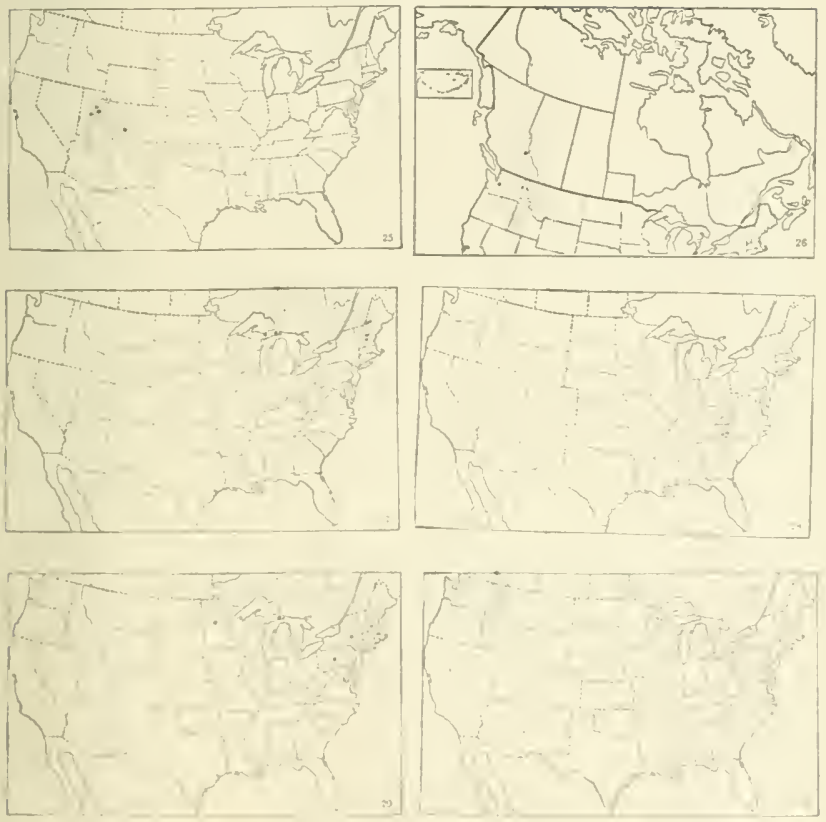

Distribution Maps of PIssodes.

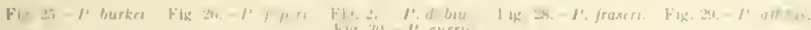

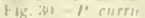




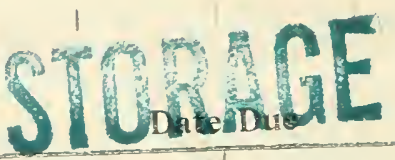

Oct 5.36 WJ

Uei-2e $=\frac{202}{22^{2}}$

2800 . 38 9nachers

FEP -41972

$\frac{\text { FEB }}{\text { NOV } 01} 1991 \mathrm{~L} / 83186$

OCT 25 Ritu

SEP 291992

SEP 30 PIET 


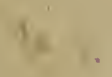

I
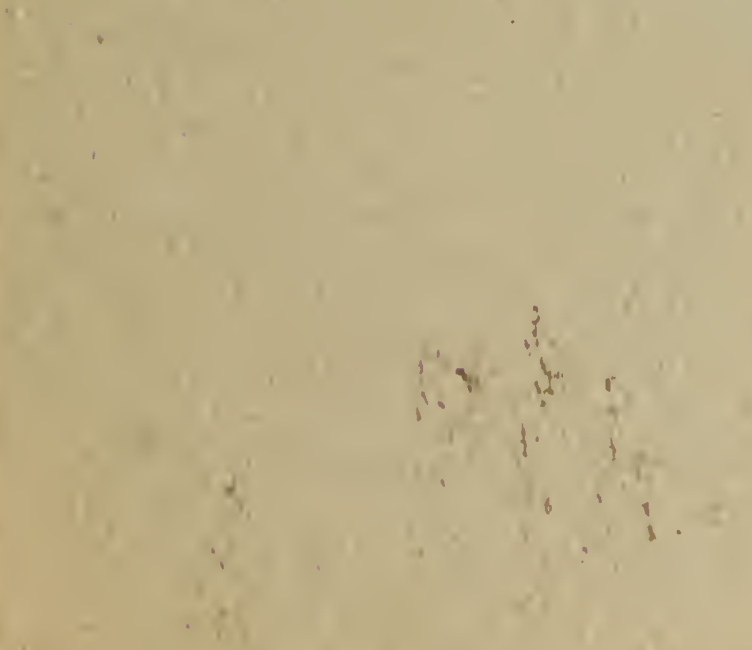


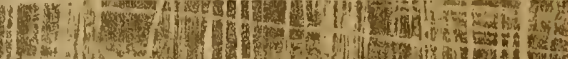

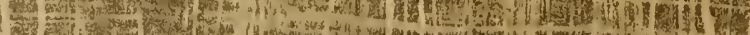
(1)

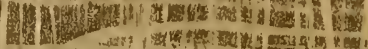
A

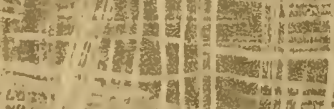
I I

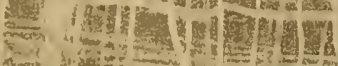
1. 19. icsistivin

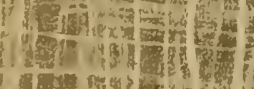

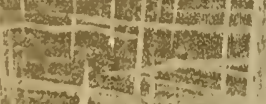

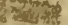

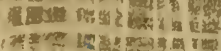
掣

1: illing

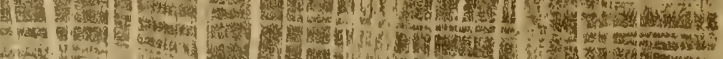

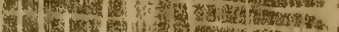
(For

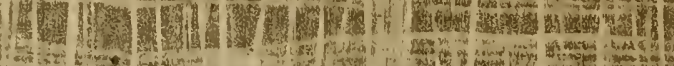

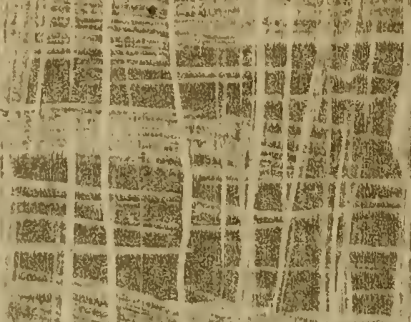
of 3.

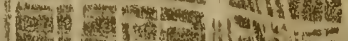

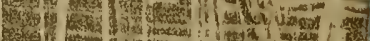

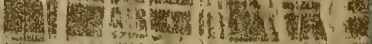

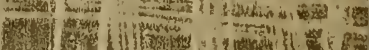

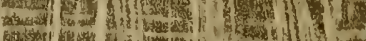

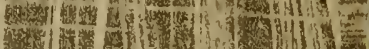

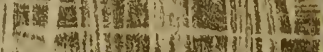

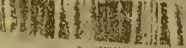

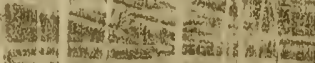
3.

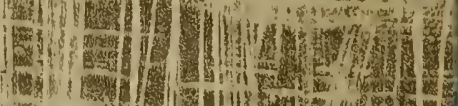

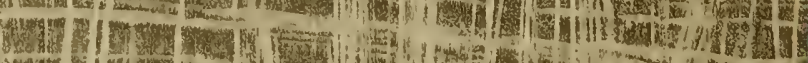
(2)

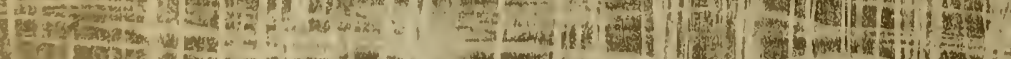
to

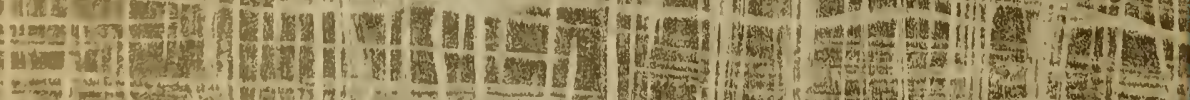

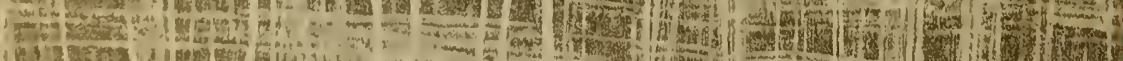
1013

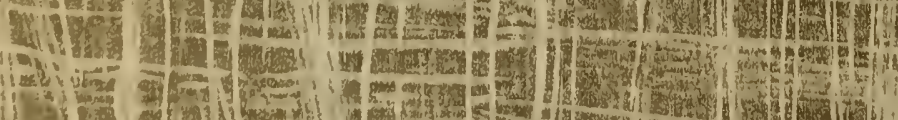
iा: 4.

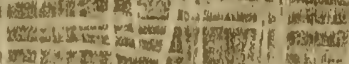

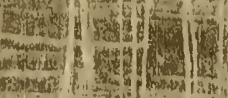

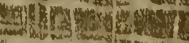

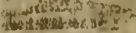

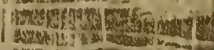

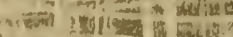
(1)

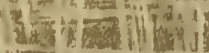

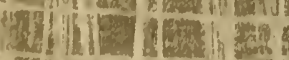

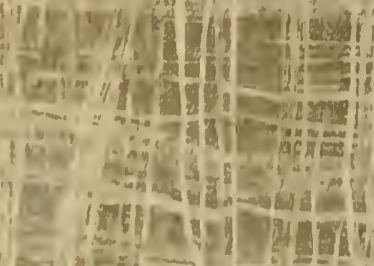
1920

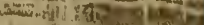

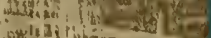
;)

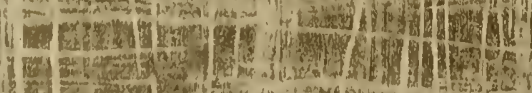
Hesirgh hes

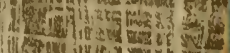

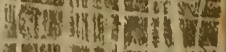
1 Irete

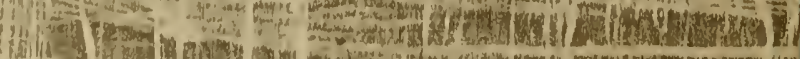
IIta m tha up

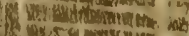

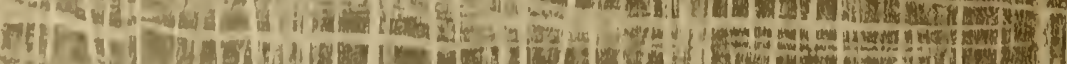

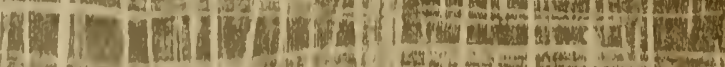
ofou 